الخلاف الفقهي في كماءة النسب وموقف نظاهر المرافعات الشرعيت

دراست فقهيت مقارنت

$$
\text { د. نورة بنت زيد مبارك الرشود }
$$

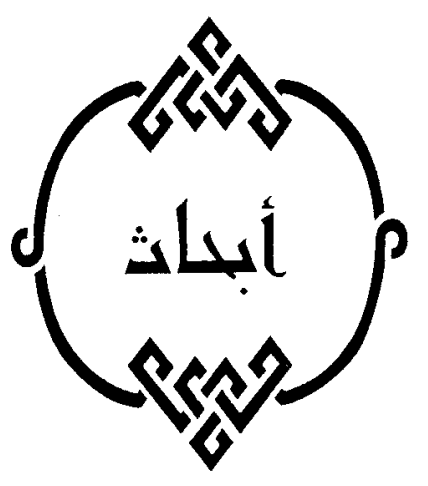

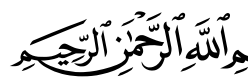

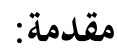

الحمد لله رب العالمين والصلاة والسلام على سيدنا محمد وعلى آله وصحبه

الطيبين.

النكاح هو المؤدى الطبيعي للغريزة التي أودعها الخالق المصور في الانسان من ذكر

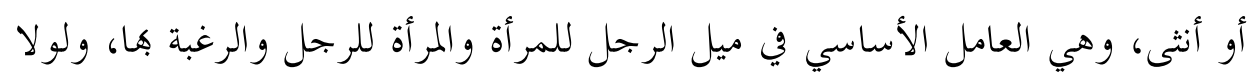
هذه الغريزة لم يتحقق هذا الميل، ولما توافرت هذه الرغبة، والإسلام حث على الزي الزواج عموما؛ لأنه سبب للغنى والفضل، و سبب للسعادة و التكاثر. فالنكاح سكن النفس والعصب، وراحة الجسم و القلب، وأُنس للأرواح، و واطمئنان

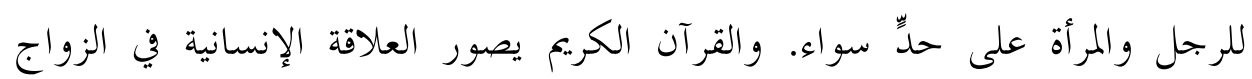

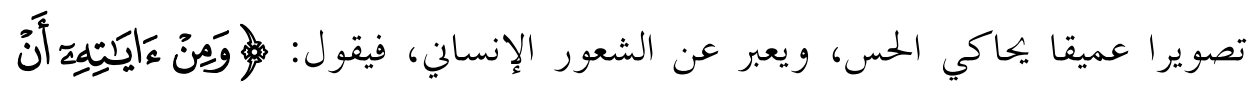

$$
-1 \cdot \mu_{-}
$$




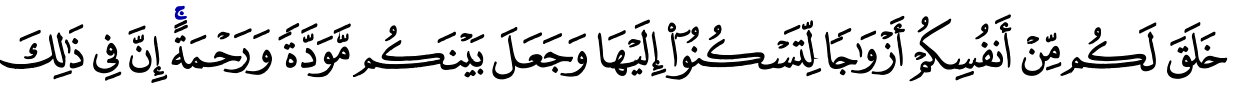

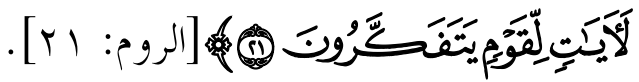

فحكمة الله تعالى خلقت الجنسين على نحو يتوافق كل منهما مع الآخر ملبيا

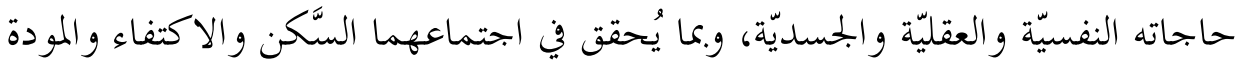

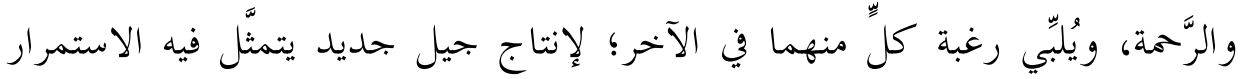
السليم للحياة، مع استقر ارها وتعاقبها.

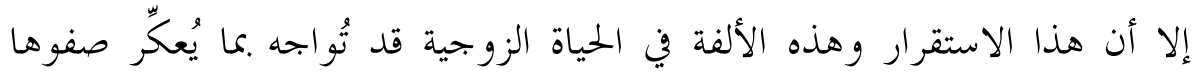
ويذهب برونقهِا، والسبب في ذلك اختلاف التوازن بين الزوجين وعدم التكافؤ بينهما؛ لاختلاف مر كز هما الديني والاجتماعي والاقتصادي. إذن فالتكافؤ مطلوب لضمان استمرار الحياة واتزاها بما يتو افق مع الطبيعة البشرية

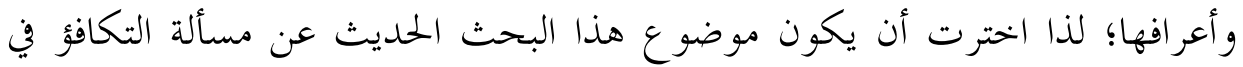

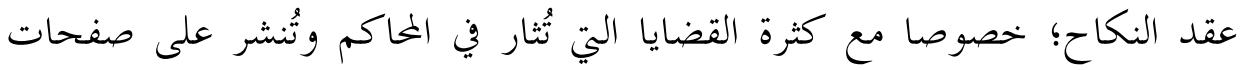

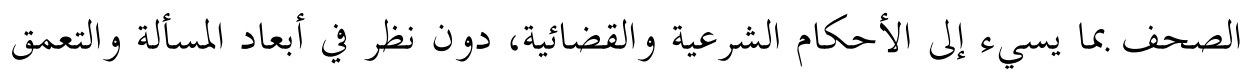
في فهمها، فنجد ردود الفعل المختلفة بين متعاطفٍ ومتشدِّد، وبين موجِّهِ وآخر مُتَّهم. فرأيت من المناسب الحديث عن هذا الموضوع في طرحٍ جديد، جامعة لآراء الفقهاء

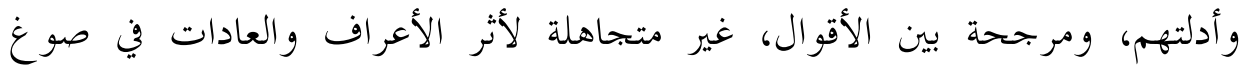

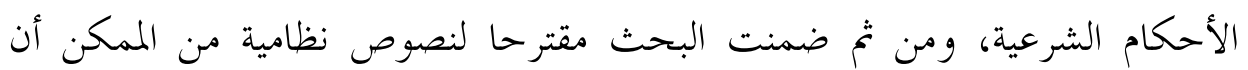
تضمَّن في نظام المرافعات الشرعية لتنظيم موضوع عن الكفاءة في عقد النكاح. 
و كانت خطة الدراسة مشتملة على التالي:

$$
\begin{aligned}
& \text { الفصل الأول: تمهيد } \\
& \text { المبحث الأول: مفهوم الكفاءة لمهن } \\
& \text { المطلب الأول: تعريف الكفاءة لغة واصطلاحها } \\
& \text { المطلب الثاني: مشروعية الكفاءة } \\
& \text { المطلب الثالث: المعتبر جانبه في الكفاءة } \\
& \text { المطلب الرابع: من يثبت له حق المطالبة بالكفاءة } \\
& \text { المطلب الخامس: نطاق اعتبار الكفاءة } \\
& \text { الفصل الثاني: الكفاءة في النسب } \\
& \text { المبحث الأول: تعريف النسب لغة واصطلاحا } \\
& \text { المبحث الثاني: أهمية النسب عند العرب }
\end{aligned}
$$

المبحث الثالث: الأحكام الفقهية المتعلقة بالكفاءة في النسب المبك المطلب الأول: أقو ال الفقهاء في حكم اعتبار النسب من خصال الكفــــاءة المعتــبرة في النكاح المطلب الثاني: نوع اشتراط الكفاءة في عقد النكاح من حيث كونه شرط صـحة أم شرط لزوم حكم اشتراط الكفاءة في عقد النكاح الفرع الأول: تعريف الشرط الفرع الثاني: أنواع الشروط في عقد النكاح 
الفرع الثالث: خلاف الفقهاء في شرط الكفاءة من حيث كوها شرط صحة أم شرط

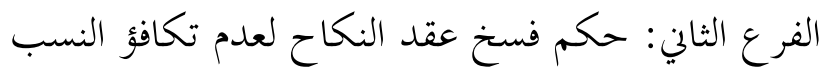
الفصل الثالث: موقف النظام السعودي من مسألة الكفاءة في النكاح وآراء القُّاة النّاة و القانونيين.

هذا وأسأل الله تعالى أن أكون قد وفقت في هذا البحث، فإن أصبت فمن الله

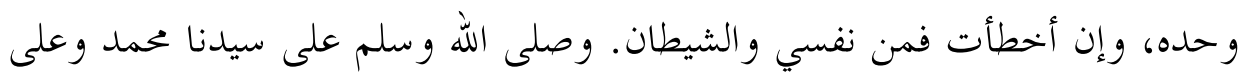

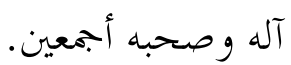




\section{المُصل الأول}

\section{تهميد}

المبحث الأول: مفهوم الكفاءة

المطلب الأول: تعريف الكفاءة لغة واصطلاحا

أوّلا: تعريف الكفاءة لغة:

المماثلة والمساواة، يقال: كافأ فلان فلاناً مكافأةً و كفاءً وهذا كفاء هذا، و كفــؤه:

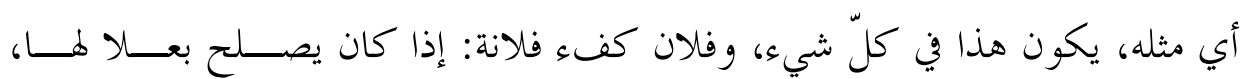

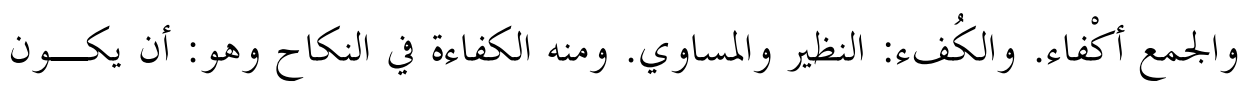

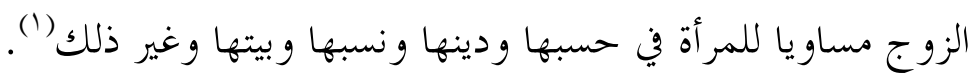

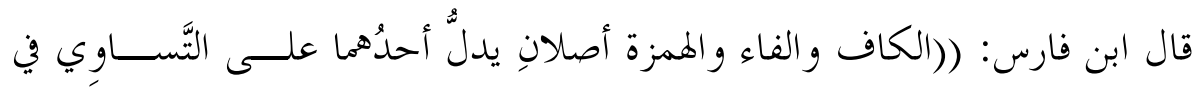

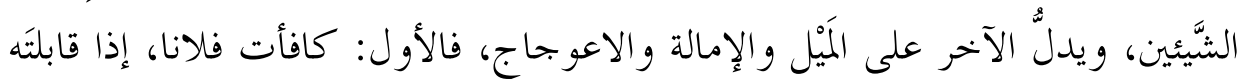

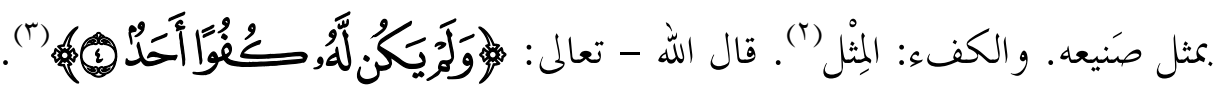
ويقال: كل شيء ساوى شيئا حتى صار مثله فهو مكافئ له، والمكافأة بين الناس من هذا(؟)،

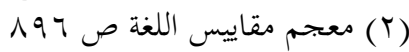

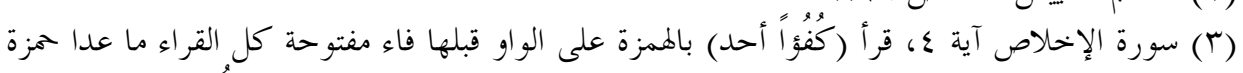

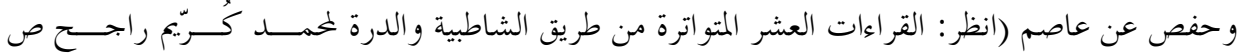


و المسلمون تتكافأ دماؤهم أي تتساوى ('). ثانيا: تعريف الكفاءة اصطلاحا: الكفاءة في النّكاح عرفت بتعريفات عدة في كتب الفقهاء جاءت كما يلي: أولا: تعريف الحنفية:

"مساو اة خحصو صة بين الرجل و المرأة(؟). ثانيا: تعريف المالكية:

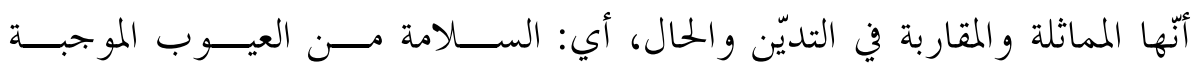

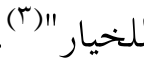

$$
\begin{aligned}
& \text { ثالثا: تعريف الشافعيّة: }
\end{aligned}
$$

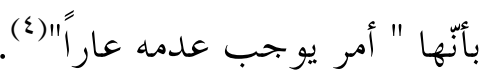

$$
\begin{aligned}
& \text { رابعا: تعريف الحنابلة: }
\end{aligned}
$$

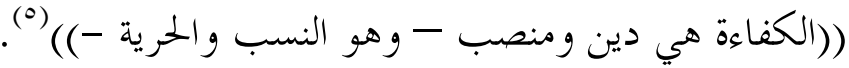

وجاء تعريف الكفاءة في القاموس الفقهي بأفا: "مساو اة الرجل للمرأة في الأمور

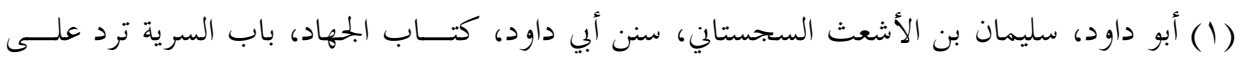

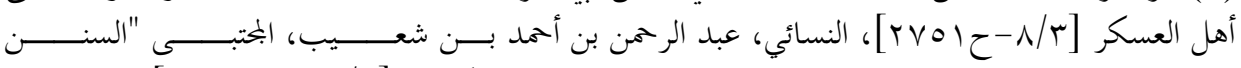

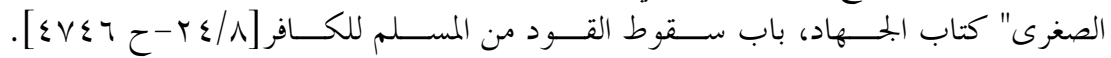

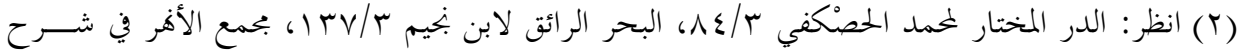

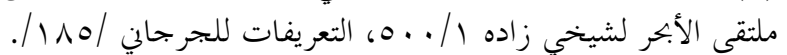

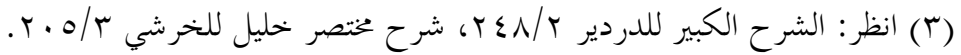

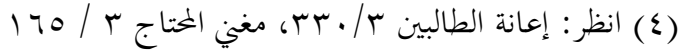

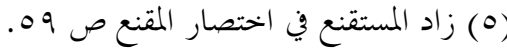


الآتية: الإسلام، و النسب، و التقوى، والحرية، والمال، و الحرفة"(1). وعرفها الدكتور بدران أبو العينين بدران بقوله: "...الكفاءة في النكاح المساواة بين

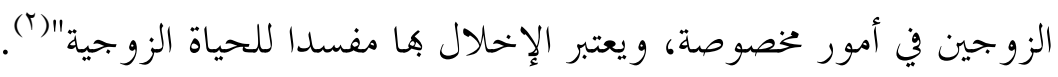

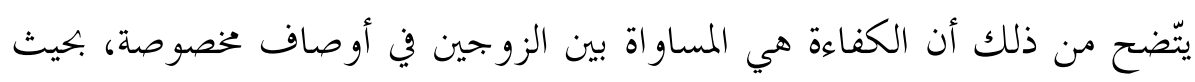

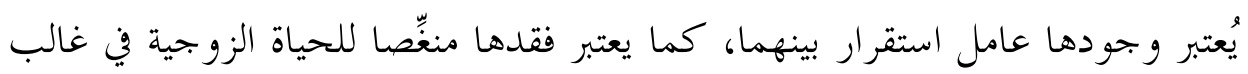
الأحوال، أو بتعبير أدق هي: أن يصلح كل من الزوجين للآخر في عرف المسلمين (؟).

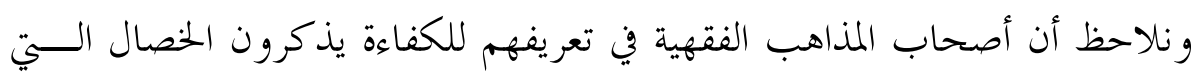
أداهم اجتهادهم إلى اعتبارها، فالمالكية مثلا في تعريفهم للكفاءة قالوا و المراد بها المماثلة

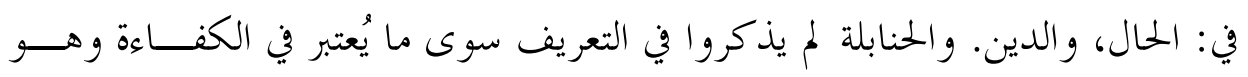

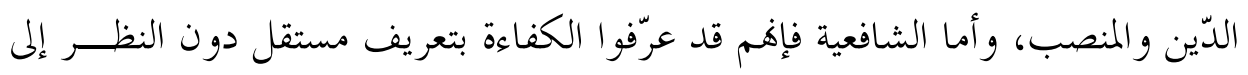

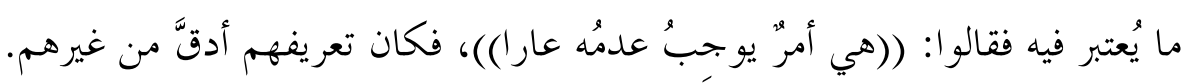

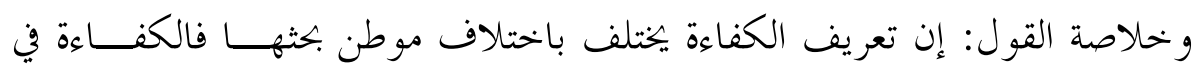

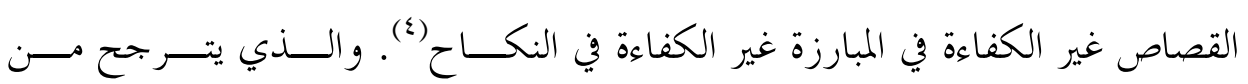

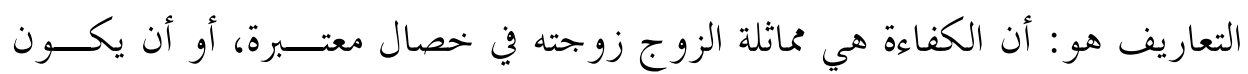
أعلى منها والتي يحق للمرأة أو وليها اسقاطها برضاهما، وبانعدامها تعيّر المرأة وأولياؤها بـ

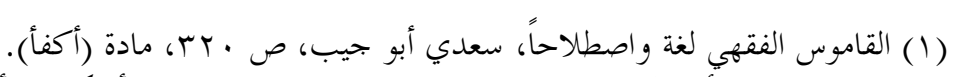

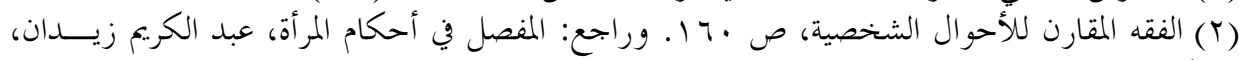

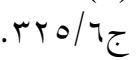

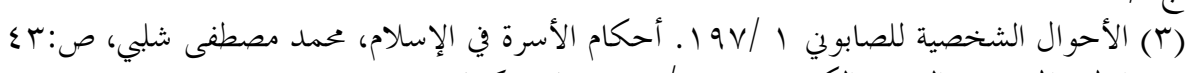

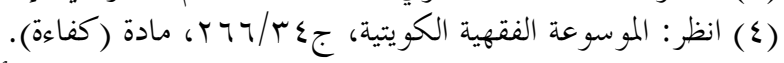

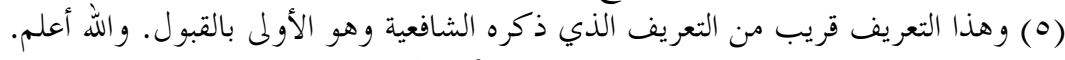




\section{المطلب الثاني: مشروعية الكفاءة}

الكفاءة وضعت لغرض استمرار العلاقة الزوجية، وتحقيق المساواة في أمور اجتماعية من أجل توفير استقرار الحياة الزوجية، وتحقيق السعادة بين الزوجين، بحيث لا تعسير

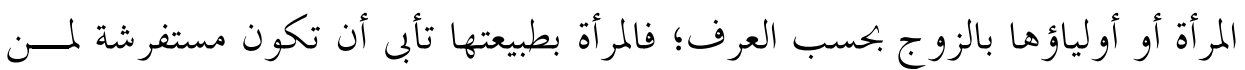
هو أدنى منها، ذلك لأن دناءة الفراش تغيضها، وتتعير كذلك إذا كان زوجها أقل شأنا

منها.

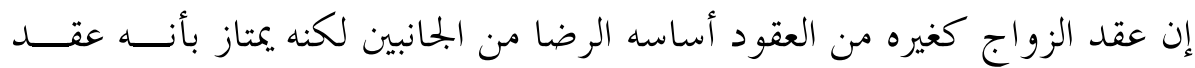
الحياة كلها يربط الأسر برباط المصاهرة، وفيه استفراش الرجل للمرأة الحرة؛ وهو نوع

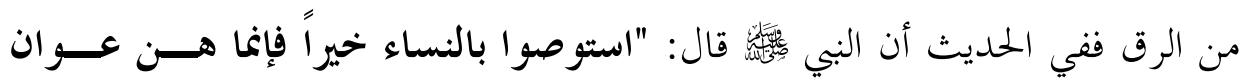

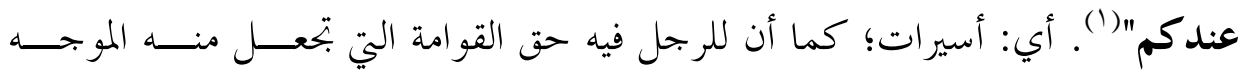

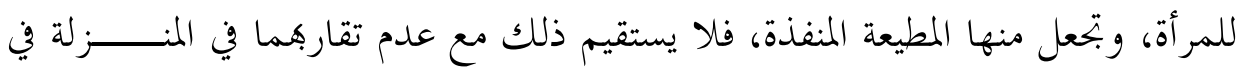
البحتمع الذي يعيشان فيه.

إن اشتراط الكفاءة في الزواج وجععلها حقا للزوجة وأوليائها يجعل الحياة الزوجيــة تثمر أطيب الثمرات في هدوء واستقرار، وبدوها لا لا يستقر لها قرار.

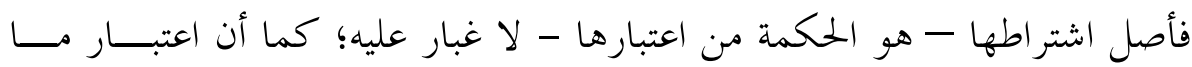
وردت به النصوص الصحيحة فيها من الدين و الحنلق لا يستطيع أحد إنككـاره؛ وإنــــا الكلام فيما وراء ذلك؛ ولعله نبع من أعراف الناس وعـــاداهم في البيئــات المختلفــــة

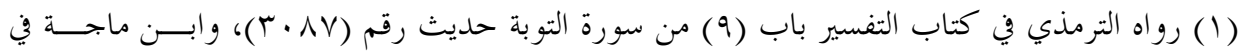

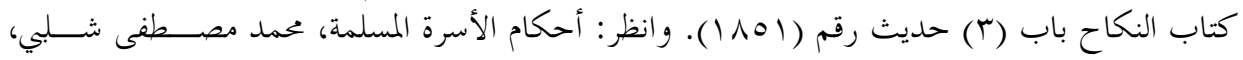
.$r \cdot v$ 
للفقهاء؛ و العرف له سلطان في مثل ذلك؛ لأنه هو الذي يكيف العار الــــي يلحـــق الأولياء في كل عقد من عقود الزواج. فبالتكافؤ يكون الحصول على ثمرة الزواج المتمثلة بالسكن الوارد في قوله - تعالى:

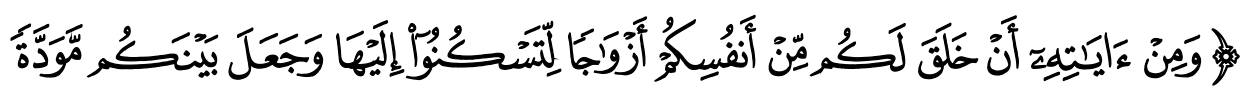

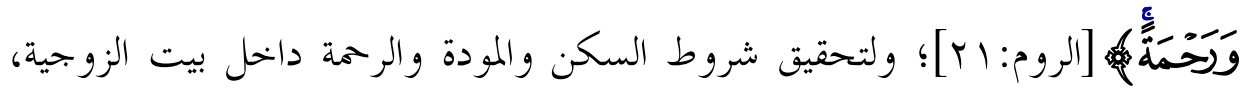
لابد من اعتبار بعض العوامل الأخرى غير الدين، فالبيوت المسلمة السعيدة تقوم على

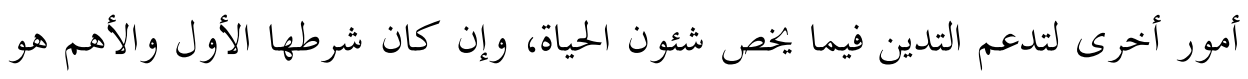
الدين، وهو الإطار الذي يحكمها، ولكن لابد من عدم الغفلة عن الشروط الأخرى، وهذا مذهب الجمهور الذي يقول: (أنه يراعى في زواج المسلمة أربعة أشياء: الدين، و الحرية، و النسب، و الصنعة، فلا تزوج المسلمة من كافر، ولا الصالحة من فاسق، وقيل:

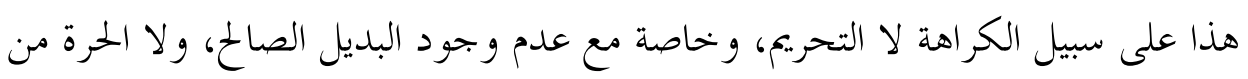

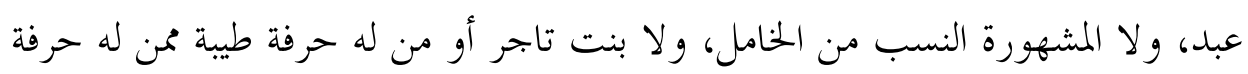

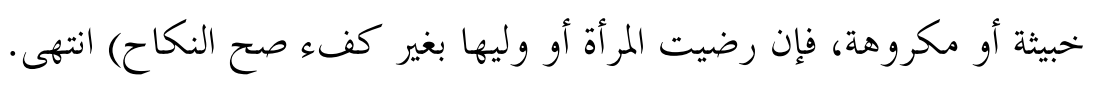

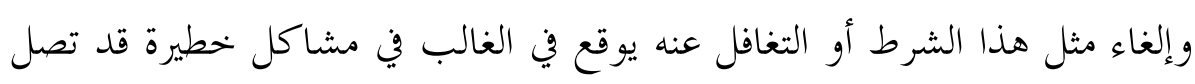
إلى حد الطلاق، فبالتكافؤ تقوي رابطة العلاقة بين الزوجين، وبالتوافق في الثقافة

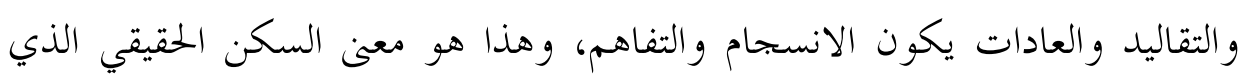

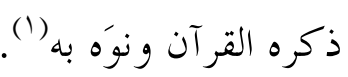

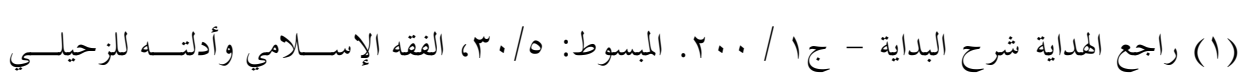


و خلاصة القول إن الإحساس بالكفاءة يولد احترام كل طرف للآخر؛ ومن ثم تنظر المرأة إلى زوجها نظرة تقدير واحترام، كما ينظر هو إليها هذه النظرة، وهذا كله يساعد على الألفة ودوام العشرة بينهما، ودوام الحياة الزوجية وتماسك الأسرة، وإيجاد النسل وتربيته التربية الصالحة. وهذا بخلاف ما لو كان الزوج غير كفء لها، فإنها ستنظر إليه نظرة استعلاء وتكبر؛ مما سيؤدي بالتأكيد إلى الجفاء بينهما، تمح الهجر

وخراب البيت و انقطاع الحياة الزوجية وضياع الأطفال (1). المطلب الثالث: المعتبر في الكفاءة

اختلف الفقهاء في المعتبر في الكفاءة هل جانب الرجال للنساء أم كذلك جانب النساء للرجال على قولين:

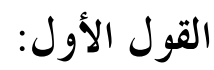

إنّ الكفاءة تعتبر في جانب الرّجال للنّساء، ولا تعتبر في جانب النّساء للرّجال، فهو حق في صالح المرأة لا في صالح الرجل، فيشترط أن يكون الرجل محاثلا أو مقاربا للمرأة

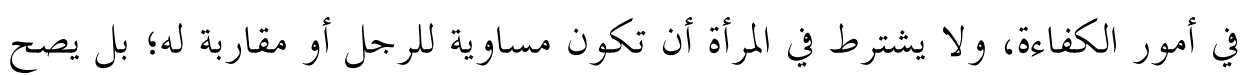
أن تكون أقل منه في أمور الكفاءة؛ لأن الرجل لا يعير بزوجة أدلى حالا منه؛ أما المرأة

$$
\text { و وأقاربها فيعيرون بزوج أقل منــزلة. وهذا قول الجمهور (r). }
$$

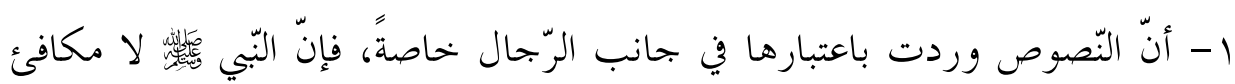

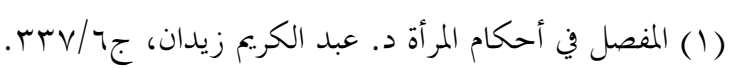

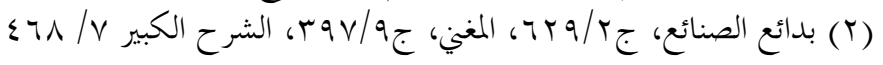

$$
\begin{aligned}
& -11 Y \text {. }
\end{aligned}
$$


له، وقد تزوج من أحياء العرب، وتزوج صفية بنت حييّ - رضي الله تعالى عنها(') وقال: ا(ثلاثة يؤتون أجرهم مرتين: الرجل تكون له الأمة فيعلّمها فيحسن تعليمها، ويؤدّبها فيحسن تأديبها، فيتزوجها، فله أجرانها (r).

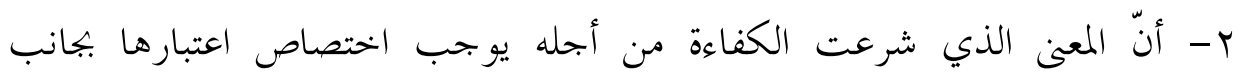

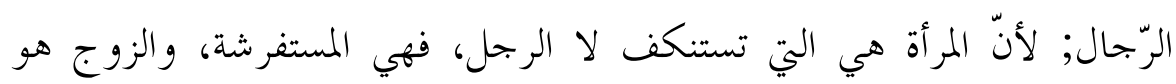

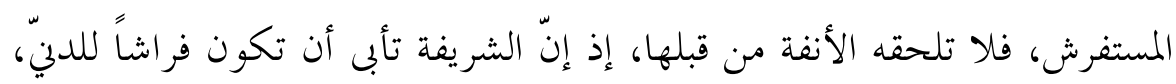

$$
\text { و الزوج المستفرش لا تغيظه دناءة الفراش (r). }
$$

r- أن الولد يشرف بشرف أبيه، لا بأمه، فلم يعتبر ذلك في الأم (ع).

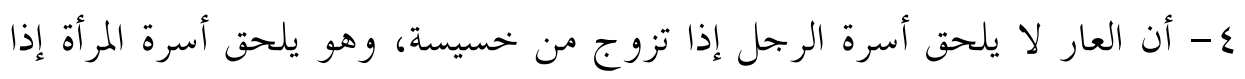
تزوجت من خسيس (0). ه - أن الرجل الرفيع في نظر الناس يرفع امرأته، والمرأة لا ترفع خسيسة زوجها إن كانت رفيعة(7). ج- أن الرجل يملك الطلاق في كل وقت، فيستطيع دفع المغبة عن نفسه بخلاف المرأة؛ فإنا لا تملك إيقاع الطلاق؛ بل أقصى ما تملك أن تطلب من القاضي التغريق في

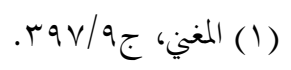

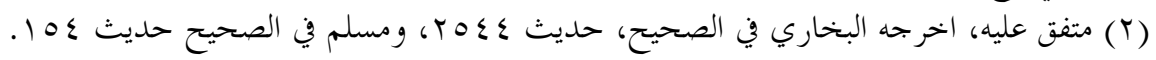

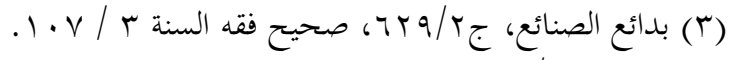

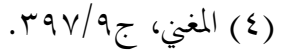

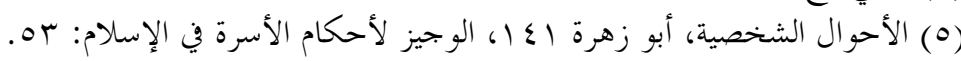

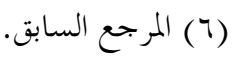

$$
-114-
$$


أحوال استثنائية خاصة(').

V - أن الزوج هو صاحب القوامة والسلطة، فلابد والأمر كذلك من أن تكون سلطته أقوى (r) (

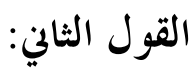

إنّ الكفاءة في جانب النّساء معتبرة . نقل هذا القول عن أبي يوسف ومحمد من الحنفية(؟). و واشترط فقهاء الحنفية الكفاءة في الزوجة في حالتين: الحالة الأولى: إذا كان الزوج فاقد الأهلية أو ناقصها، وزوَّجه أولياؤه البعيدون، أو

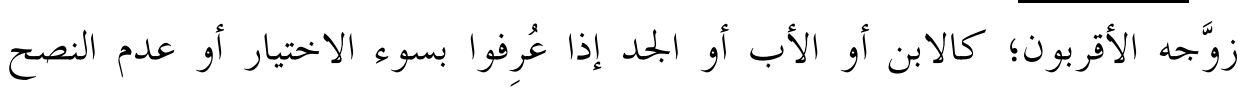
للمولى عليه (ع). الحالة الثانية: و كذا إذا و كَّل الزوج من يزوجهه تو كيلا مطلقان(ه). فإنه يشترط في هاتين الصورتين توافر الكفاءة في الزوجة، واشترطت الكفاءة في تروته

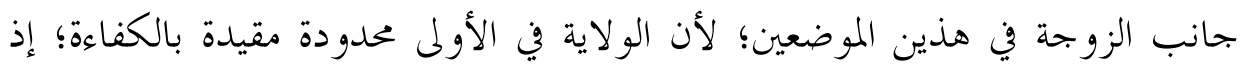
الولي في هذه الحال مقيد بالمصلحة الظاهرة، أما في الصورة الثانية فلأن العرف قيد الإطلاق بالمرأة الكفء (7).

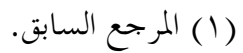

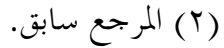

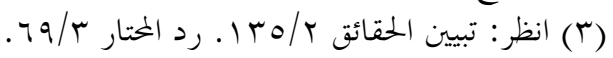

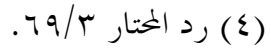

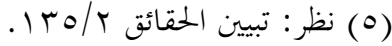

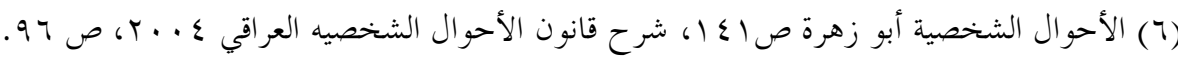

$$
\begin{aligned}
& -11 \leqslant
\end{aligned}
$$




\section{المطلب الرابع: من يثبت له حق المطالبة بالكفاءة}

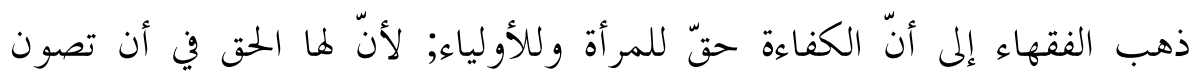
نفسها عن ذلّ الاستفراش لمن لا يساو يها في خصال الكفاءة، فكان لها حقّ في الكفاءة أما الأولياء فإنّهم يتفاخرون بعلوّ نسب الخنتن، ويتعيرون بدناءة نسبه، فيتضررون بذلك؛ فكان لهم أن يدفعوا الضرر عن أنفسهم بالاعتراض على نكاح من لا تتو افر فيه خصال الكفاءة؛ فاقتضى ذلك تقرير الحقّ لهم فيها، ولو لم يكن لهم حق في الكفاءة لما كان لهم حق الاعتراض؛ بل فسخ النكاح.

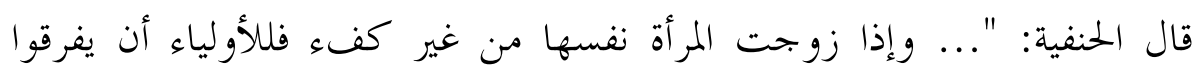
بينهما؛ دفعا للعار عن أنفسهم..." (1). قال الكمال بن الهمام: مقتضى الأدلة وجوب إنكاح الأكفاء، وهذا الوجوب يتعلق بالأولياء حقّا لها، وبها حقّا لهم، لكن إنّما تتحقق المعصية في حقّهم إذا كانت صغيرة؛

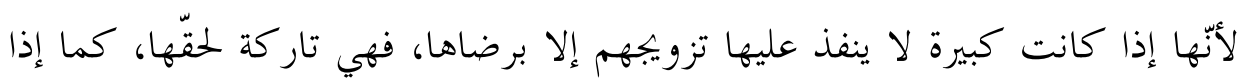

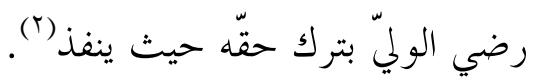

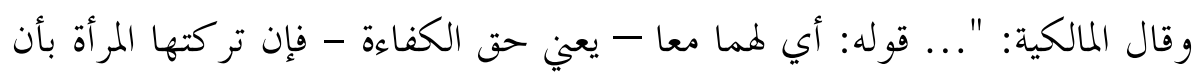
رضيت بغير كفء و لم يرض الولي بتركها فللأولياء الفسخ ما لم يدخل، فإن دخل فلا فسخ، والحاصل أن المرأة إن تركتها فحق الولي باق و العكس..."("َ).

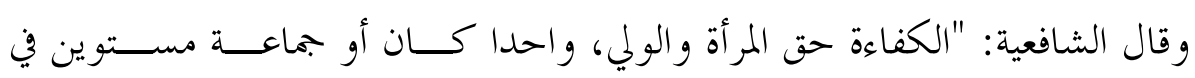

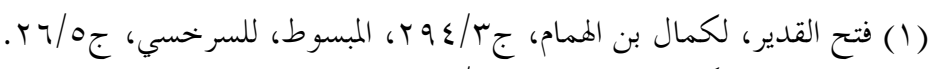

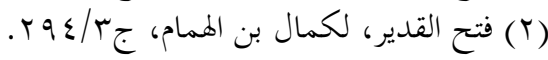

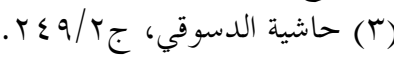


درجة، فإن زوجها بغير كفء وليها المنفرد برضاها أو أحد الأولياء برضاها ورضـي الباقين صح النكاح، فالكفاءة ليست شرطا للصحة، ولو زوجها أحد الأوليــاء بغسير كفء برضاها دون رضى الباقين، لم يصح على المذهب، وفي قول يصح ولهم الخيــار في فسخه، وقيل: يصح قطعا، وقيل: لا يصح قطعا" (1).

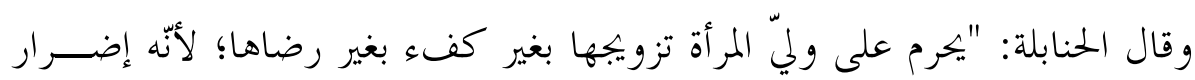

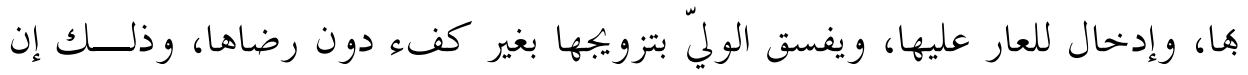
تعمده، وإذا رضيت المرأة بالزوج بدون كفاءة ورضي كذلك الأولياء صح النكــــاح، وإن لم يرض بعضهم، فهل يقع العقد باطلا من أصله أو صحيحا فيه روايتــان عــنـ

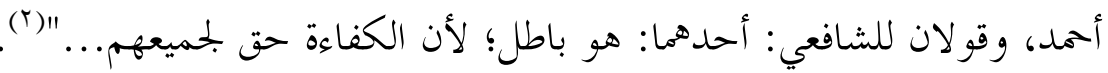
فالكفاءة في الزواج من حلال النصوص هي حق للمرأة وحق للأولياء، ويثبت هذا الحق لكل منهما على حدة، بحيث لو أسقط أحدهما حقه لم يسقط حسـق الآخهـر إلا بإسقاطه. وإن اتفقا المرأة والولي على إسقاط حقهما سقط هذا الحق و لم يكن لأحدهما طلب الفسخ عند انعدام الكفاءة، وإن أسقط أحدهما حقه بالكفاءة لم يعد هذا اسقاطا لحق

$$
\text { الآخر (") كما سيأتي توضيحه. }
$$

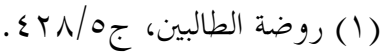

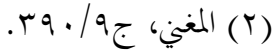

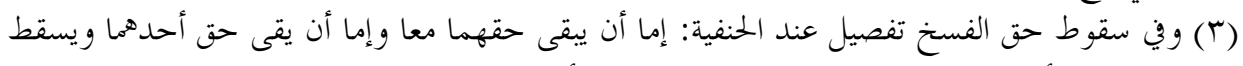

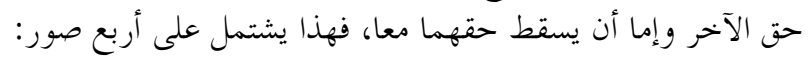

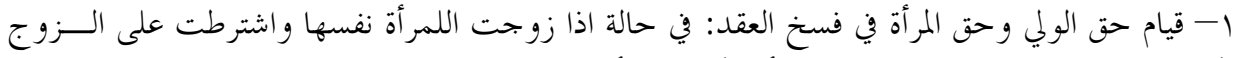

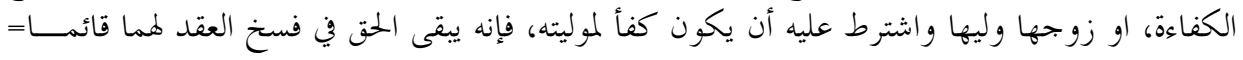




\section{المطلب الخامس: نطاق اعتبار الكفاءة}

الصّفات المعتبرة في الكفاءة في الجملة هي:

$$
\text { - }
$$

r - ب و النّسب، وقد ينبر عنه بالحسب

$$
\text { ع - - - و الحرّية - والحرفة }
$$

$$
7 \text { - } 1 \text { - والتنقي من العيوب المثبتة للخيار }
$$

لكنّ الفقهاء لم يتفقو ا على اعتبارها كلّها كاملةً، بل كان لهم فيها تفصيل: أو لا: عند الحنفية:

تعتبر الكفاءة عند الحنفية في سبعة أمور: الحنديه:

الكفاءة في النسب - الكفاءة في الدين والتقوى - الكفاءة في الصنائع - الكفاءة في

= عند عدم تحقق الكفاءة.

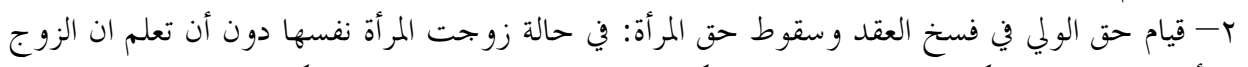

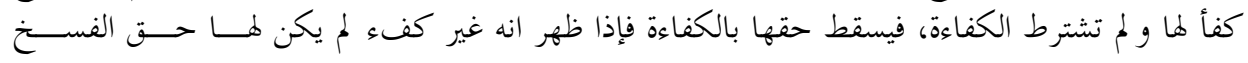

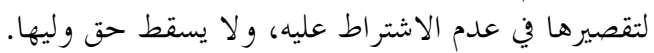

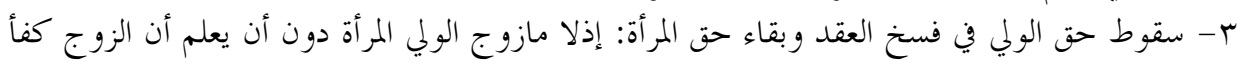

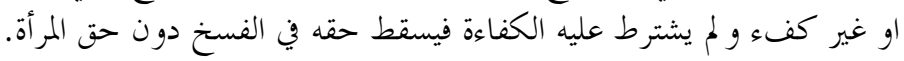

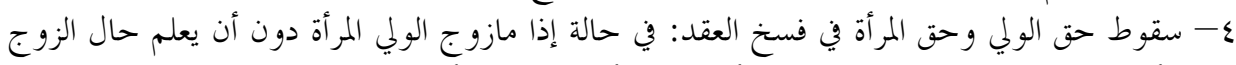

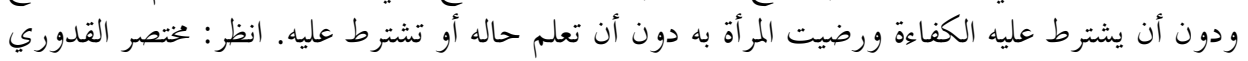

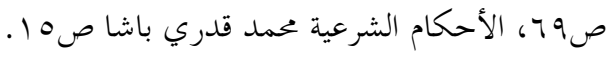


الحرية - الكفاءة في المال - الكفاءة في الإسلام - الكفاءة في العقل (1).

ثانيا: عند المالكية:

الكفاءة عند المالكية تعتبر في ستة أمور:

الدين - الحال (r) - النسب - الصنعة - الحرية - اليسار (يعني المال و الغنى)(r).

ثالثا: عند الشافعية: - n

الكفاءة عند الشافعية تعتبر في أربعة أمور:

السالامة من العيوب المثبتة للخيار - الحرية - النسب - العفة: وهي الدين

$$
\begin{aligned}
& \text { و الصالاح - الحرفة(ع). } \\
& \text { رابعا: عند الحنابلة: } \\
& \text { الكفاءة عند الحنابلة تعتبر في خمسة أمور: }
\end{aligned}
$$

الدين - المنصب: (وهو الحسب والنسب) - الحرية - الصناعة - اليسار(0).

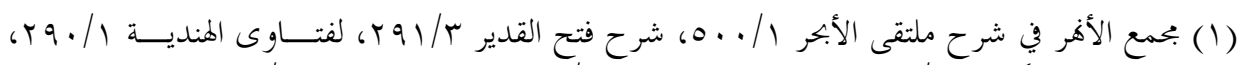

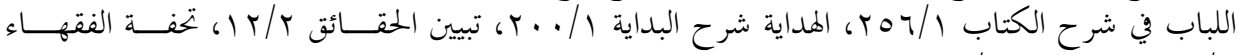

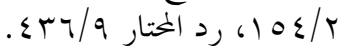

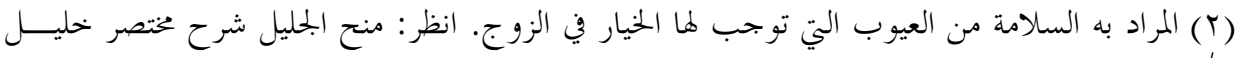
r.

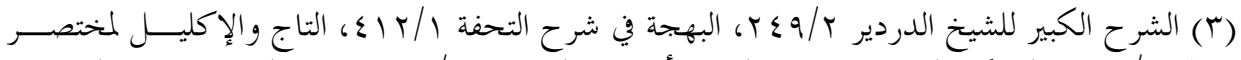

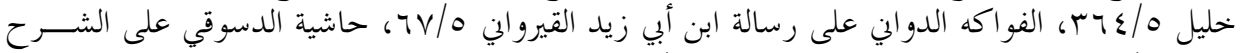

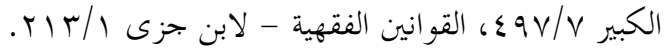

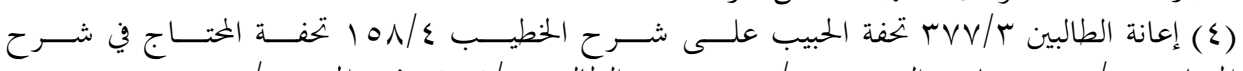

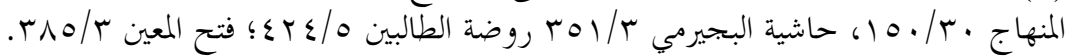

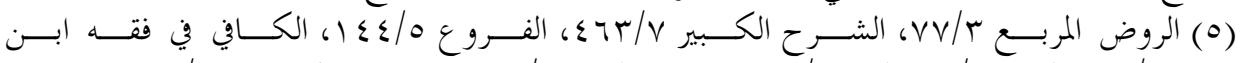

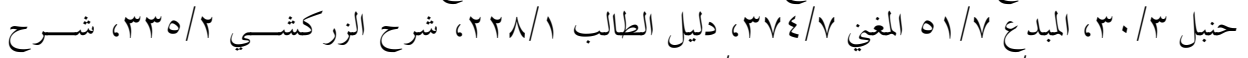

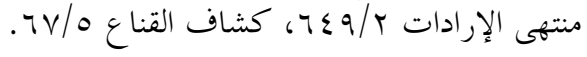




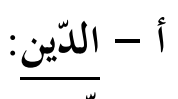

إنّ من خصال الكفاءة الدّين، أي: المماثلة والمقاربة بين الزوجين في التديّن بشرائع الإسلام، لا في بجرد أصل الإسلام، وهذا قول جمهور الفقهاء من الحنفية، والمالكية،

\section{و الشافعية، والحنابلة(1).}

قال أبو حنيفة وأبو يوسف: والفئه

لو أنّ امرأةً من بنات الصالحين زوجت ونت نفسها من فاسق كان للأولياء حقّ

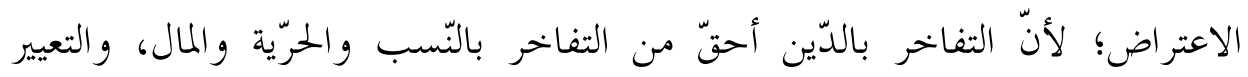

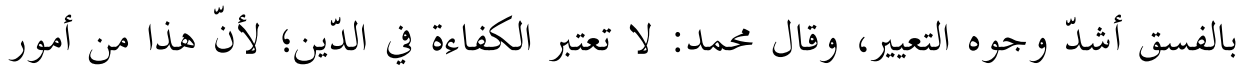
الآخرة، و الكفاءة من أحكام الدّنيا، فلا يقدح فيها الفسق إلا إذا كان شيئا فاحشا، بأن كان الفاسق ممن يسخر منه ويضحك عليه ويصفع، فإن كان ممن يهاب منه، بأن كان أميرا قتالا فإنّه يكون كفءا؛ لأنّ هذا الفسق لا يعدّ شيئا في العادة، فلا يقدح في

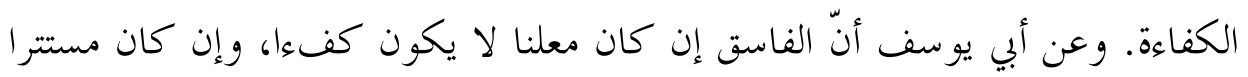

$$
\text { يكون كف اء| (r) }
$$

وقال المالكية:

المر اد بالدّين الإسلام مع السلامة من الفسق، ولا تشترط المساواة في الصلاح، فإن

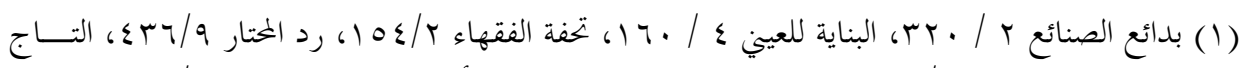

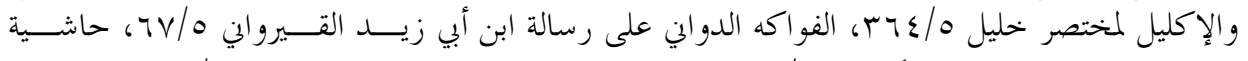

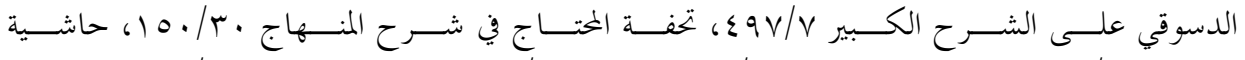

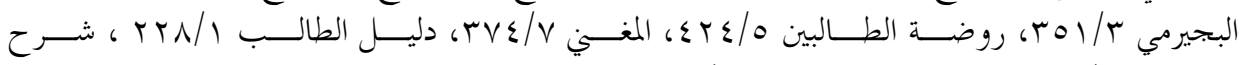

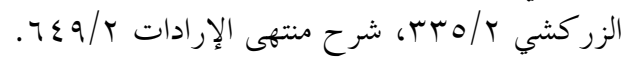

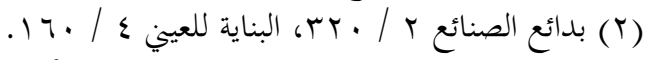


فقد الدّين و كان الزوج فاسقاً فليس بكفء (1).

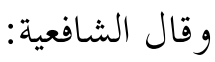

من خصال الكفاءة الدّين والصلاح والكفّ عما لا يحلّ، و الفاسق ليس بكفء للعفيفة، وغير الفاسق - عدلا كان أو مستورا - كفء لها، ولا تعتبر الشّهرة بالصلاح، فغير المشهور بالصالح كفء للمشهورة به، والفاسق كفء للفاسقة مطلقا إلا إن زاد فسقه أو اختلف نوعه، و المبتد ع ليس بكفء للعفيفة أو السنّية(؟). وقال الحنابلة: الدّين مما يعتبر في الكفاءة؛ فلا تزوج عفيفة عن الزّنا بفاجر، أي بفاسق بقول أو فعل أو اعتقاد. قال أحمد في رواية أبي بكر: لا يزوّج ابنته من حروريّ قد مرق من الدّين، ولا من

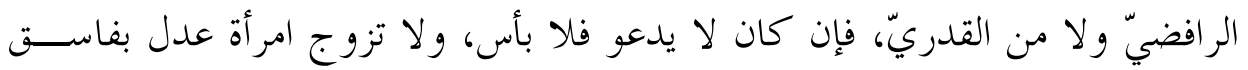
كشارب خمر؛ لأنّه ليس بكفء، سكر منها أو لم يسكر، و كذلك من سكر من خمـــر

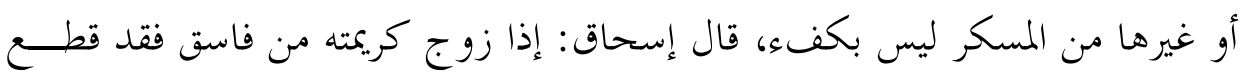
(r)

$$
\text { اختلفو ا فيها على قولين: الخرية: }
$$

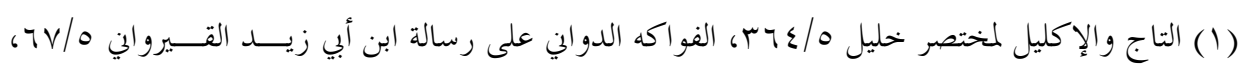

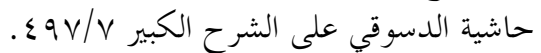

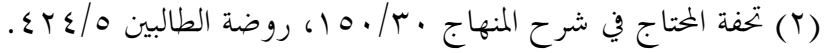

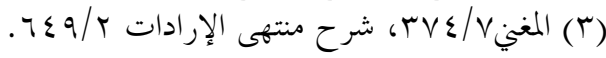




\section{القول الأول:}

إنّ الحرّية من خصال الكفاءة، فلا يكون القنّ أو المبعض أو المدبر أو المكاتب

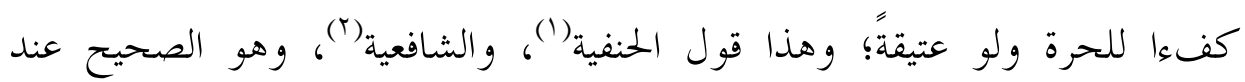

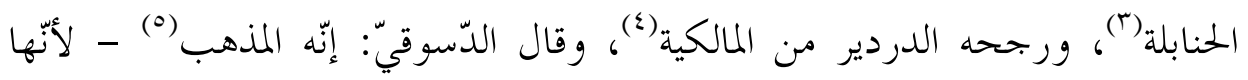
تتعير به؛ إذ النقص والشين بالرّقّ فوق النقص والشين بدناءة النّسب.

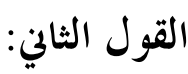

"يجوز نكاح العبد عربية، وهو قول ابن القاسم من المالكية(؟).

$$
\text { ج - الحرفة: }
$$

هي العمل الذي يمارسه الانسان لكسب رزقه وتدبير أمور حياته ومعيشته، و الحرفة

الدنيئة ما دلت ملابستها على انخطاط المروءة وسقوط النفس، كملابسة القاذورات. والكفاءة في الحرفة: أن تكون حرفة الزوج قريبة من حرفة الزوجة ووالدها، الزها،

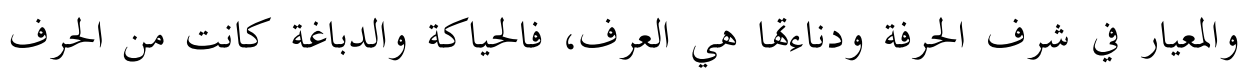

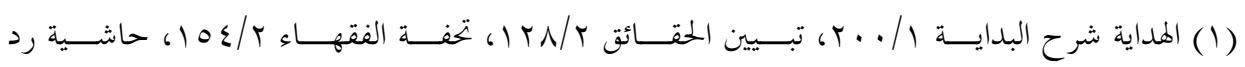

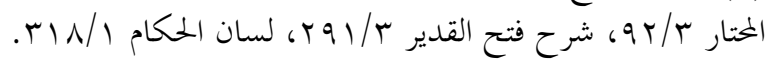

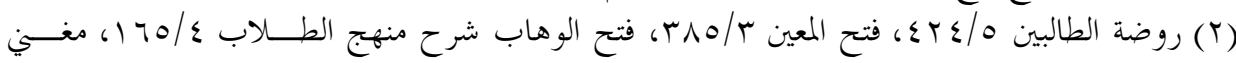

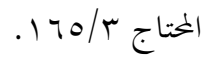

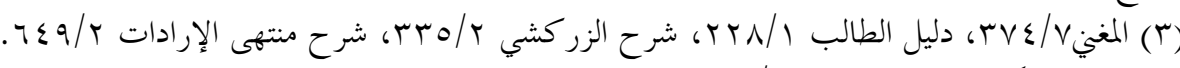

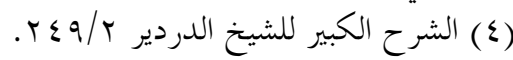

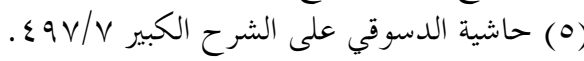

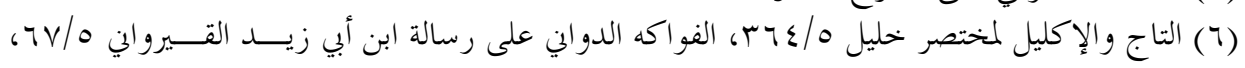

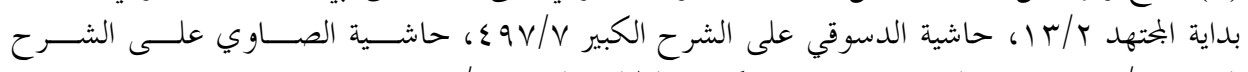

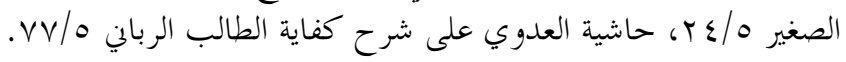

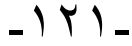


الدنيئة، لكن في الوقت الحالي لم تعد كذلك (').

وقد اختلف الفقهاء في اعتبارها على قولين:

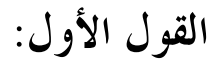

اعتبار الحرفة في الكفاءة في النّكاح، وإليه ذهب الحنفية - في المفتى به وهو قول أبي

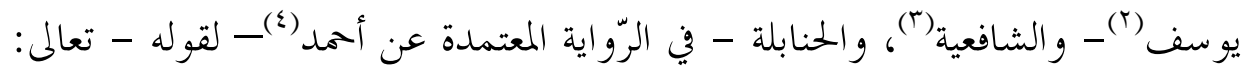

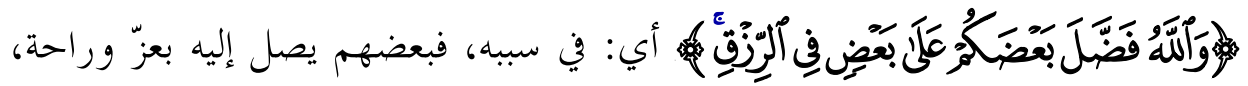
و بعضهم بذلّ و مشقة.

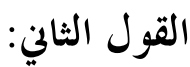

إنّ الحرفة غير معتبرة في الكفاءة في النّكاح، روي عن أبي حنيفة(ْ)، ورواية عن أحمد(1)، وروي نحو ذلك عن أبي يوسف صاحب أبي حنيفة. قال أبو يوسف: إنّها

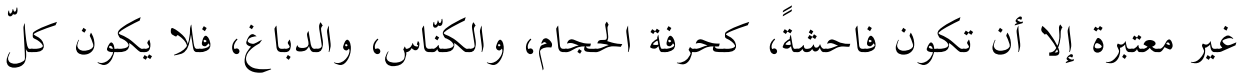
منهم كفء بنت العطار و الصيرفيّ و الجوهريّ(V). - د المال:

والمقصود به الكفاءة المالية؛ فلا يكون الفقير كفءا للغنية؛ لأن التفاخر بالمال أكثر

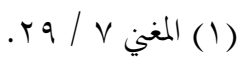

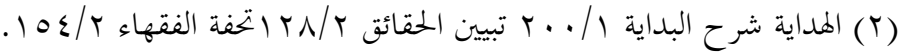

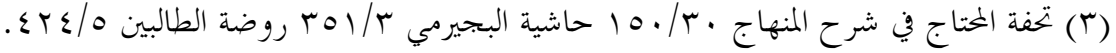

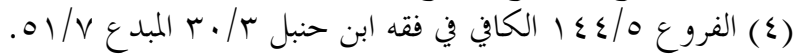

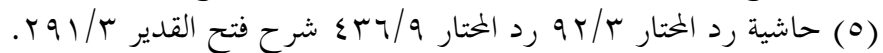

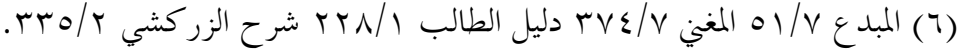

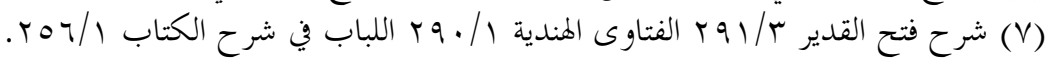


من التفاخر بغيره، وخصوصا في زماننا هذا؛ ولأنّ ذلك معدود نقصا في عرف الناس، ويتفاضلون فيه كتفاضلهم في النّسب وأبلغ، كما أن على الموسرة ضررا في إعسار زوجها لإخلاله بنفقتها ومؤنة أولادها، ولهذا ملكت الفسخ بإخحلاله بنفقتها ومؤنة ولنة

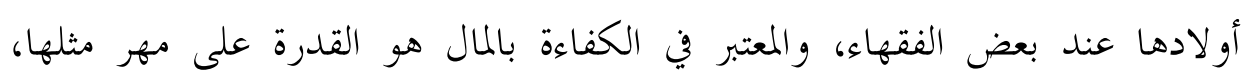
و القدرة على النفقة عليها، فإن كان الزوج قادرا على ذلك فإنه يكون كفءاء لها، وإن لهان كان لا يساويها في اليسار. اختلف الفقهاء في اعتبار اليسار(1) من خصال الكفاءة في النّكاح أو عدم

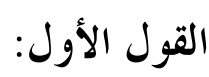

اعتبار اليسار، وهو من من خصال الكفاءة في النّكاح، فلا يكون الفقير كفء

الغنية

وهو مذهب الحنفية(r)، و الحنابلة - في الرّو اية المعتمدة(؟)هـ وهو مقابل الأصحّ عند

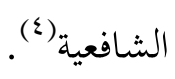

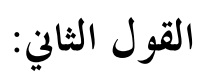

إنّ اليسار لا يعتبر في الكفاءة؛ وهو الأصحّ عند الشافعية(ْ)، وروي عن أحمد عدم

$$
\begin{aligned}
& \text { (1) (1) و ويعبّر عنه الحنفية بالمال. }
\end{aligned}
$$

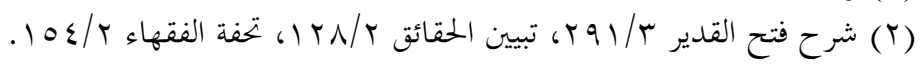

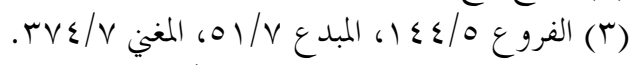

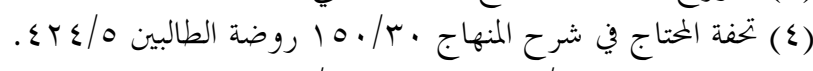

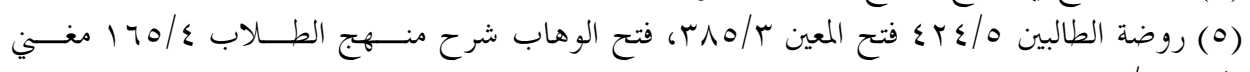

$$
\begin{aligned}
& -1 Y \text { L }
\end{aligned}
$$

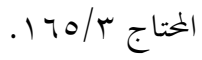




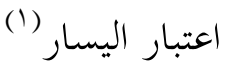

\section{ه - المالامة من العيوب:}

والمقصود سلامة الزوج من العيوب المثبتة للخيار في عقد النكاح، فمن به بعضها، كجنون، أو جذام، أو برص ليس كفءا للسليمة؛ لأن النفس تعاف صحبة من به بعضها، و اختلفوا في أنّ السلامة من العيوب المثبتة لخيار فسخ النّكاح من خصال الكفاءة في النّكاح أم لا على قولين:

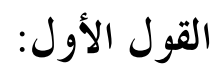

إنّ السلامة من العيوب المثبتة لخيار فسخ النّكاح من خصال الكفاءة في النّكاح.

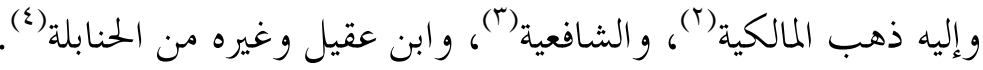

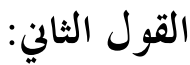

لا تعتبر في الكفاءة السلامة من العيوب، وهو قول الحنفية(ْ)، وأكثر الحنابلة(7)،

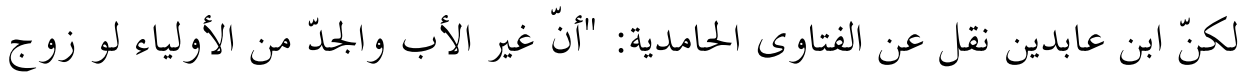

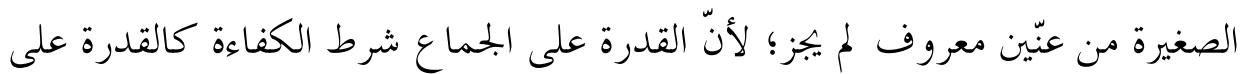

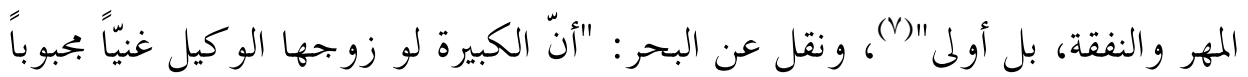

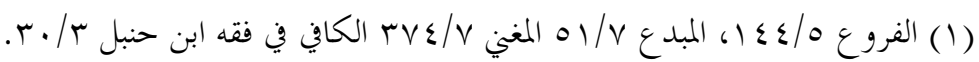

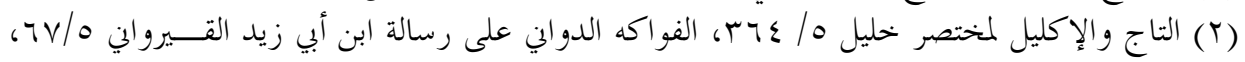

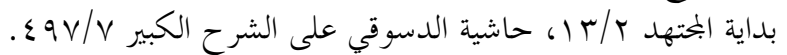

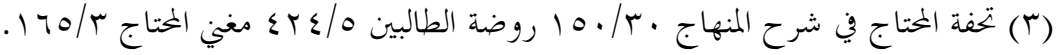

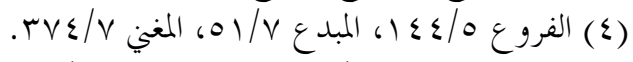

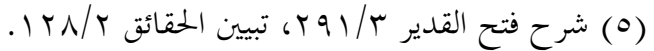

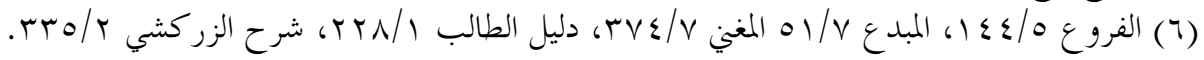

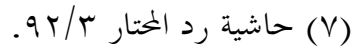


جاز، وإن كان لها التفريق بعد"(1). والأصح أن السلامة من العيوب لا يعتبر من خصال الكفاءة؛ لأها تثبت الخيار في فسخ النكاح لكال الزوجين.

$$
\text { و - النسب: }
$$

وهذا موضوع البحث، وسنتحدث عنه باستفاضه في المبحث التالي.

وخحلاصة القول في خصال الكفاءة والراجح فيها هو ما ذهبت إليه اللجنة الفقهية التي أعدت الموسوعة الفقهية الكويتية حيث قالت: "وترى اللجنة أن عامة الصفات المعتبرة في الكفاءة بحسب ما تقدم لدى الفقهاء مناط اعتبارها العرف، وقد عبر الفي الفقهاء

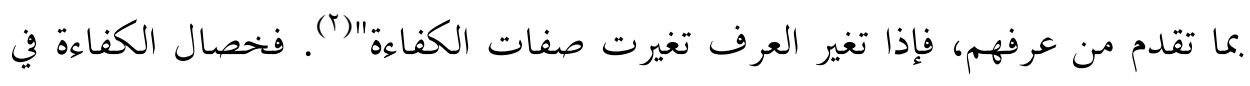
غير الدين (التقوى والصلاح) تختلف من عصر إلى عصر، ومن بلد إلى بلى بلد (r). *** 


\section{الفصل الثاني}

\section{الكفاعة في النسب}

\section{المبحث الأول: تعريف النسب لغة واصطلاحا}

أولا: تعريف النسب لغة

"بفتح النون والسين" نَسَبُ القَرَاباتِ وهو و واحدُ الأَنْساب، قُال ابن فارس: النــــون

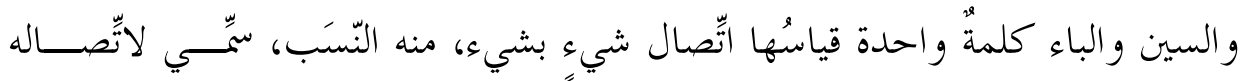

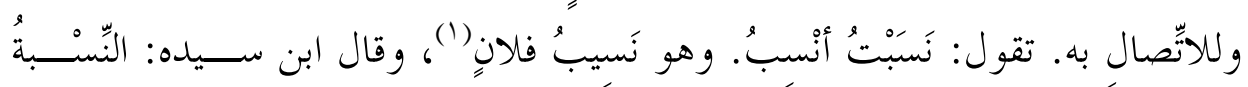

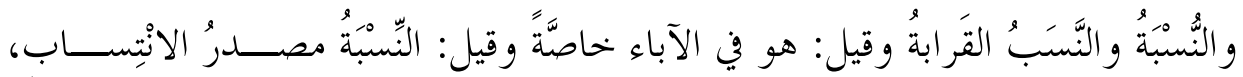

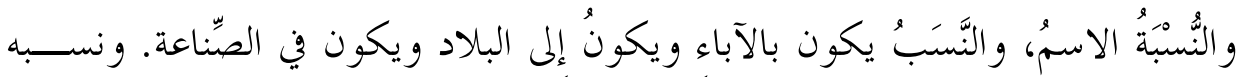

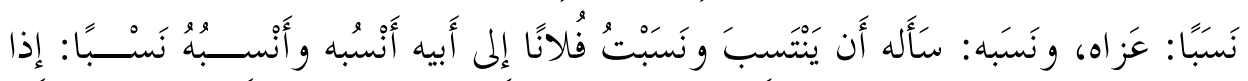

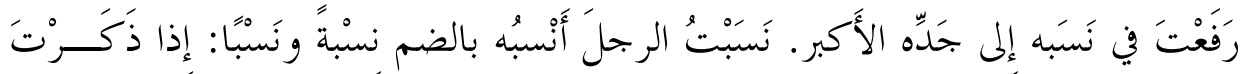

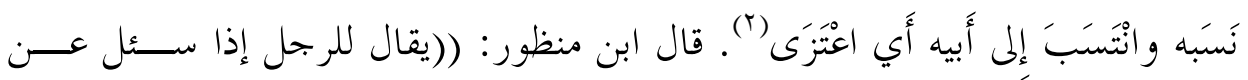

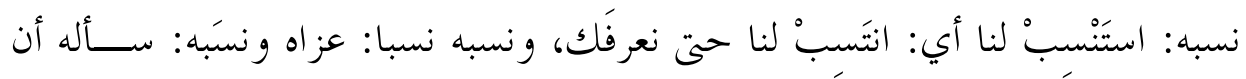

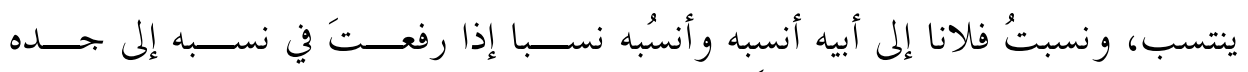

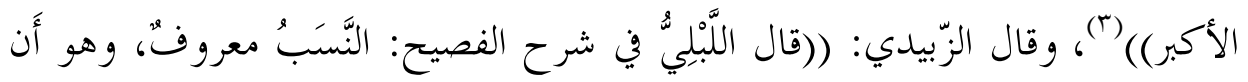

$$
\begin{aligned}
& \text { (1) معجم مقاييس اللغة ص 911) }
\end{aligned}
$$

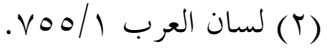

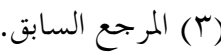




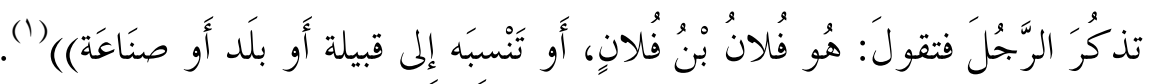
وقد استخدم النسب بعد ذلك في الدلالة على واحد من المعنيين الآتيين:

$$
\text { أولاً: عقب الرجل الرقل }
$$

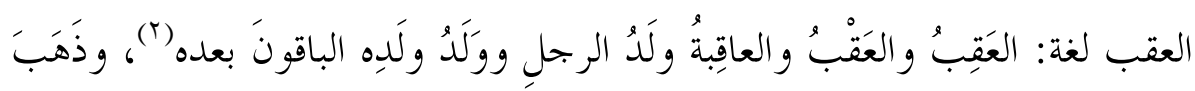

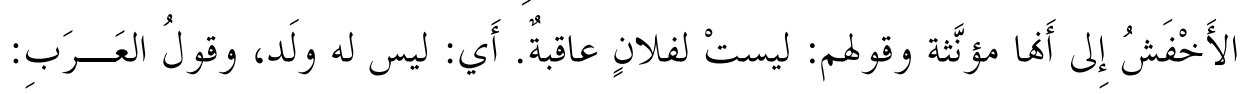

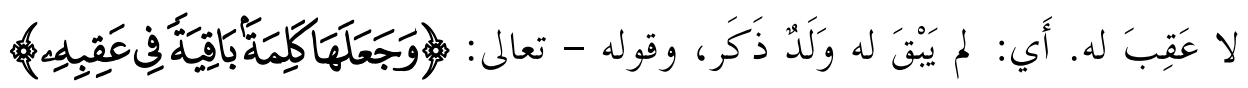

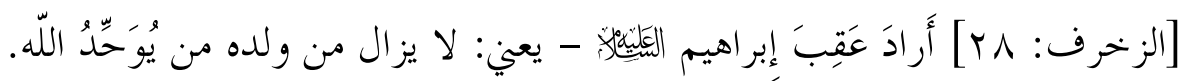

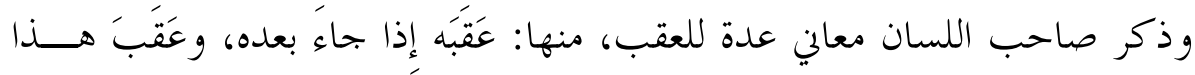

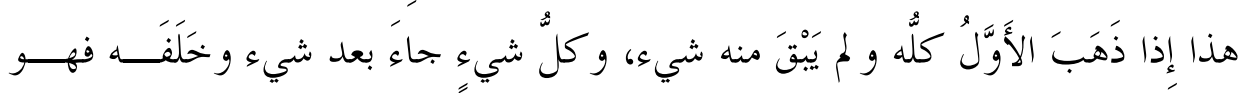

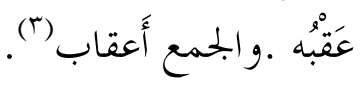
ثانيا: القرابـــة

قال الفيّومي: ((تم استعمل النسب وهو المصدر في مطلق الوصلةِ بالقرابة، فيقــال

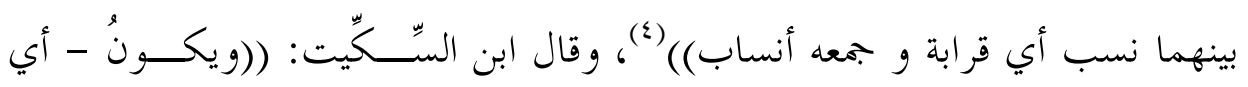

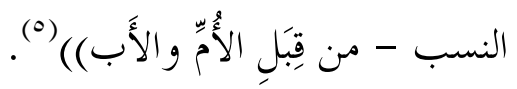

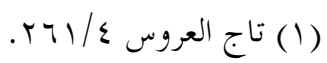

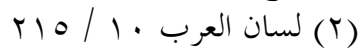

$$
\begin{aligned}
& \text { (ك) المرجع السابق. }
\end{aligned}
$$

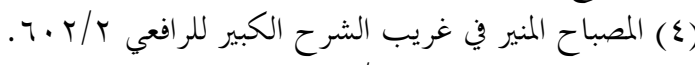

$$
\begin{aligned}
& -I T V_{-}
\end{aligned}
$$

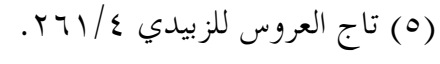


ثانيا: تعريف النسب اصطلاحا

عرّف بعض الفقهاء النسب بتعريفات مختلفة منها:

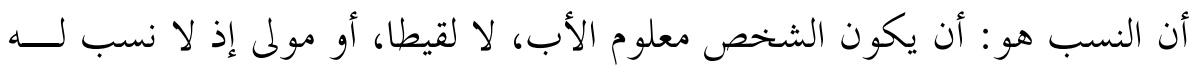
معلو م (1) - معن. وعرفه الزخشري فقال: النسب ما رجع إلى ولادة قريبة(؟). وقال ابن أبي تغلب: النسب هو القرابة، وهي الاتصال بين إنسانين بالاشــتر اك في ولادة قريبة أو بعيدة(") وقيل هو : صلة الإنسان بأصوله من الآباء والأجداد(ع).

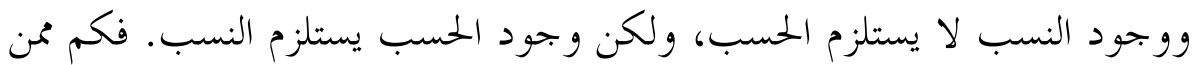
له آباء وأصول لكن ليس لهم في المآثر و المفاخر شيء يذكر، ولكن و.جـــود الحسب

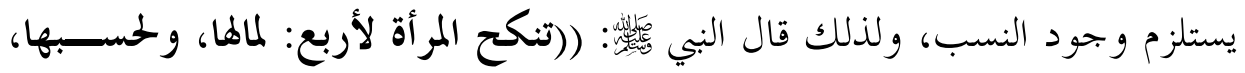
وبمالها، ولدينها، فاظفر بذات الدين تربت يداك)() (•) وتحديد معنى النسب بدقة، وبيان جهاته المعتبرة شرعا له أهميته في الفقه الإسلامي، فإن كثيرا من الحقوق والواجبات الشرعية جاءت منبنية عليه، كما ترتبط به أحكــام

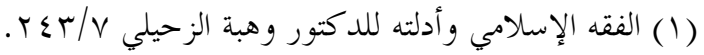

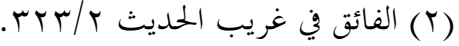

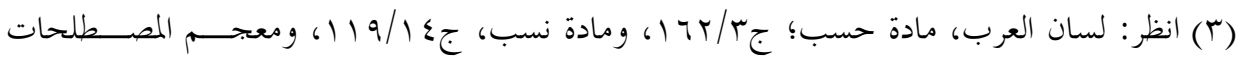

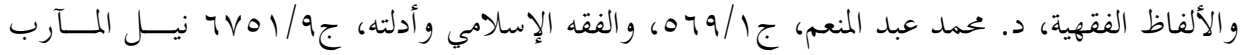

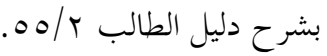

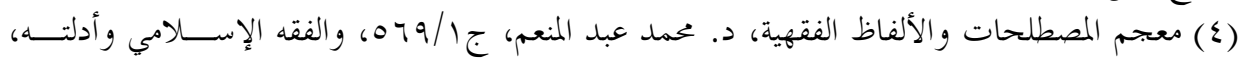

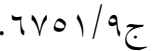

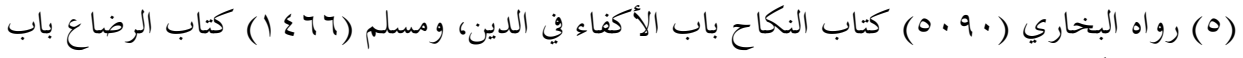

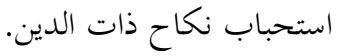


فقهية عديدة تكلمّ عنها الفقهاء في مواضع متفرقة من مدوناهم الفقهية، واختلفــــوا في جوانب منها؛ كتلك الأحكام المتعلّقة بالكفاءة في النكاح، و النفقة، و الوصيّة... (1).

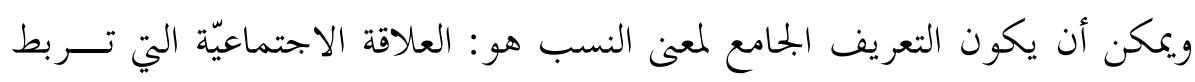

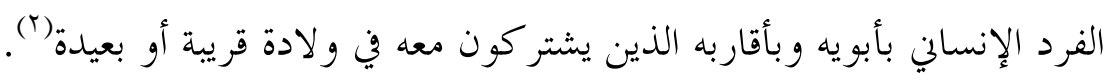

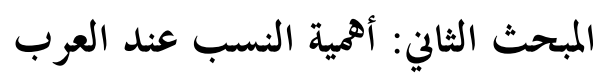

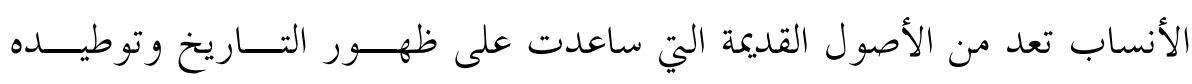

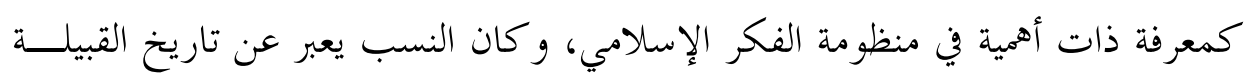

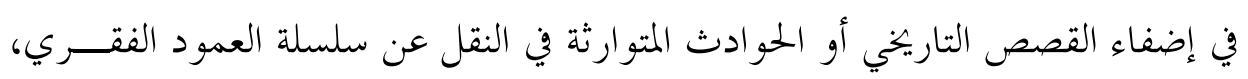

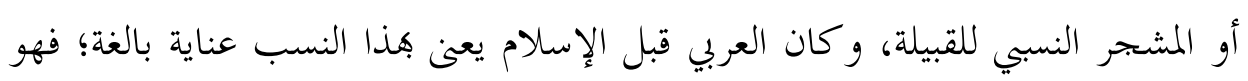
كيانه الذي يعتز به ويفخر، ووجوده الذي يميزه عن الآّخرين.

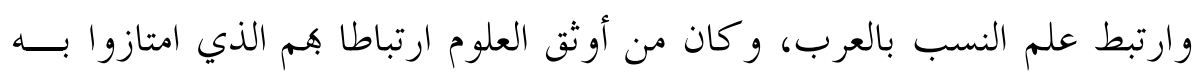

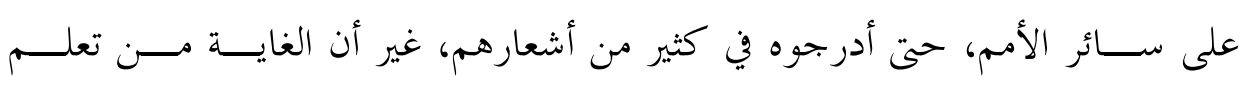

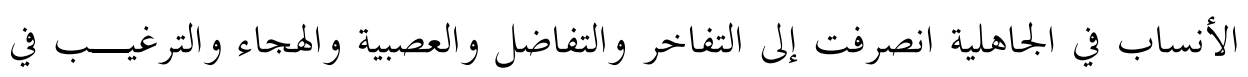
أخذ الثأر. وقد عزى ابن عبد ربه سبب اهتمام العرب بأنساهم لكونه سبب التعارف، و سلم

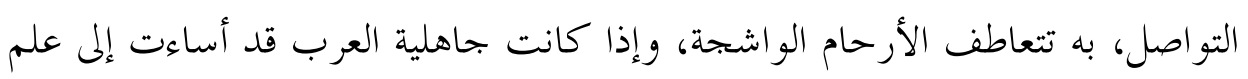

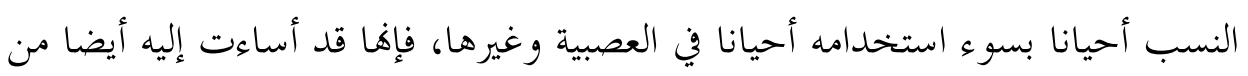
(1) النسب ومدى تأثير المستجدات العلمية في إثباته ص هץ. فتوح البلدان ص • بآ؛؛ الطبقات الكــبرى r.t $r / r / / T$ ( المصدر السابق ص ع (r) 
ناحية عدم التدوين الذي تميز به العصر الجاهلي، وبسبب غياب التدوين اضطر العرب

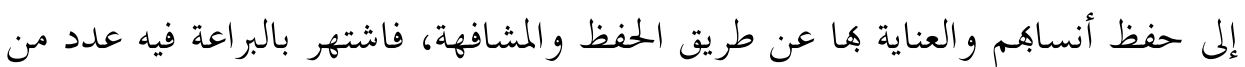
أبناء العرب الذين كان لهم السبق في وضع أسس نظريات الترقية والتهذيب للسلالات منذ القديم، فقد روت المصادر أن المنذر بن أبي حمضة الأكبر الهمداني أمر الهمدانيين أن

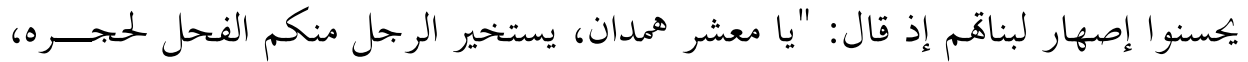
ولا يستخيره لكريمته". وقد جاء الإسلام مؤكدًا لهذه النظريَّة على لسان رسوله الكريم

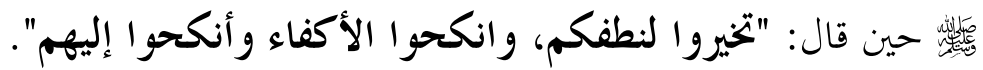
ويمكن القول بأن اعتناء العرب قديما بضبط الأنساب كان للتفضيل بـــين الأقـــوام و الأفر اد؛ إذ كان النسب والهوية العشائرية للفرد هو ما يحلّد مرتبته عندهم وما ينــزله

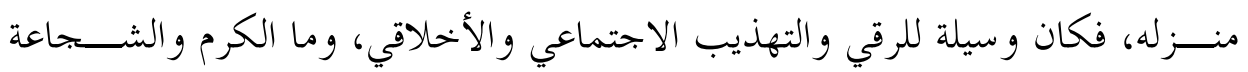
و المروءة و النبل و الحكمة وغير ذلك من الصفات الجليلة إلا وسيلة من وسائل النَسَـــبـ التي تفاخر بها الأجداد.

بل كان النسب عندهم هو السياج والحياض الذي يجمع أبناء القبيلة ضمن إطــــاره في زمن لم يكن يعرف فيه العرب معنى الدول المقسمة ذات الحدود لـــوطن واحســــ، وكان له دور هام في تجميع القبائل ضد العدو الخارجي كوسيلة سياسيَّة إداريَّة. وكانت حصانة الأسر و العشيرة معروفة بين الأمم، فقال الله - تعالى- في المتمردين

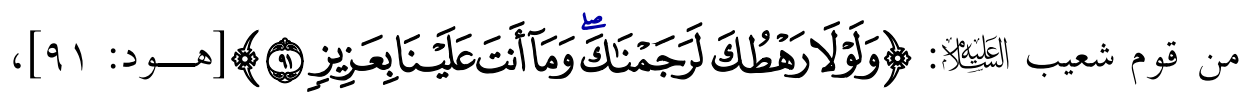

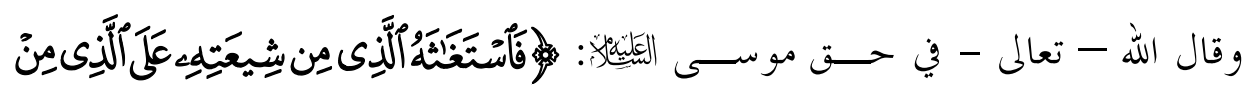

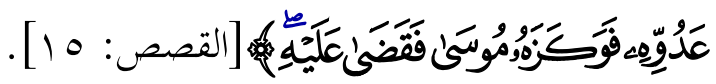
$-1 \mu \cdot$ 
وكانت أول عناية يوجهها الإسلام للعشيرة بكوها أولى بالرعاية في هـــذا الــــين

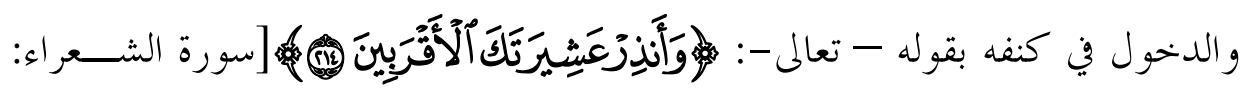

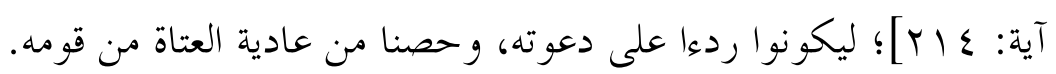

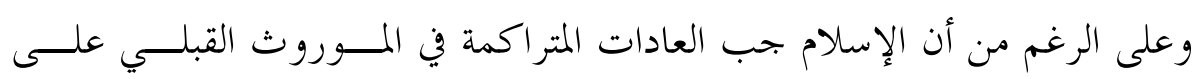

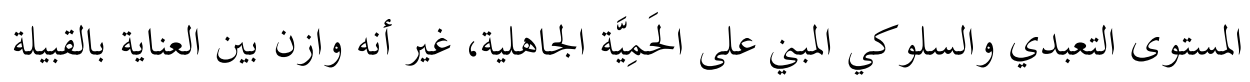

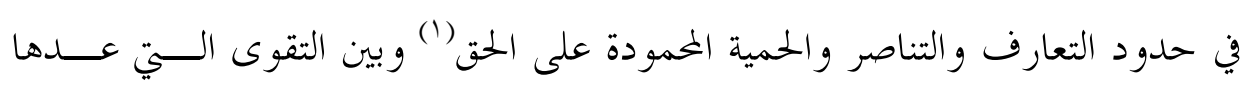

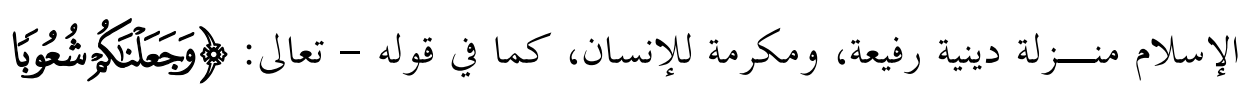

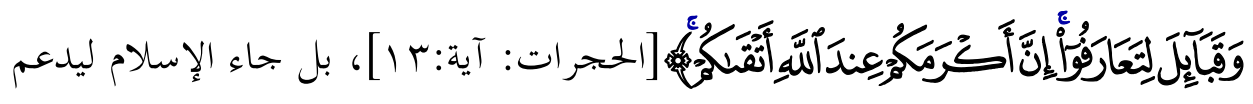

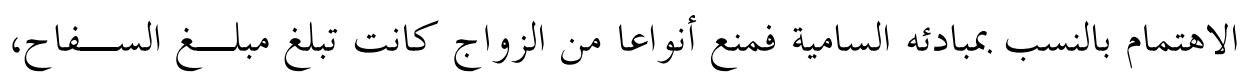

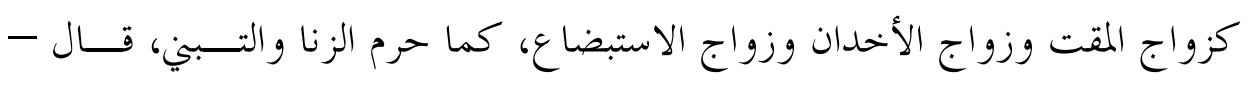

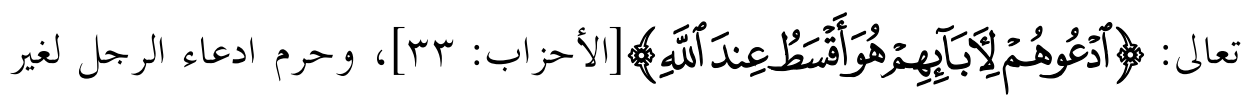

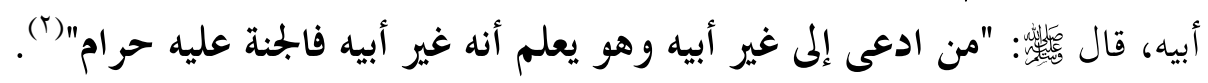
وقد وظف الإسلام النسب وتعلمه في خدمة صلة الرحم، وهي غاية إسلامية سامية

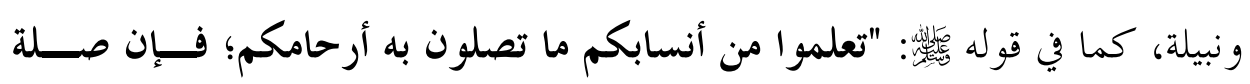

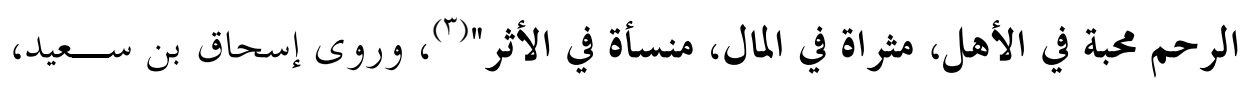
قال: حدثي أبي قال: كنت عند ابن عباس فأتاه رجل فسأله: من أنت؟ قال: فمَتَّ له اله

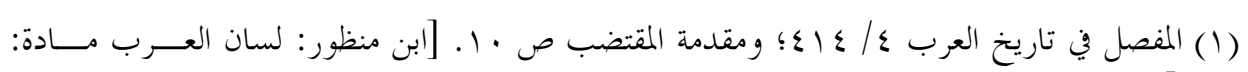




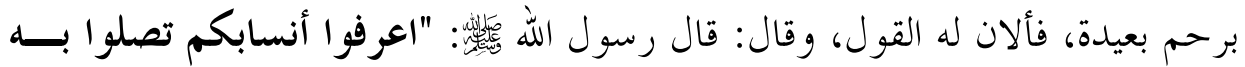

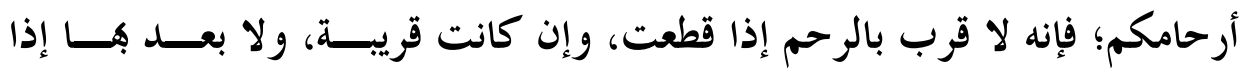
وصلت وإن كانت بعيدة"، ورووى عمارة بن غزية، عن أبي سلمة بن عبد الـــرحمن، عن عائشة - رضي الله عنها - أن رسول الله لهُ

وأُتِ أبا بكر الصديق؛ فِإنه أعلم قريش بأنسابها حتى يلخص لك نَسبَي" (1)

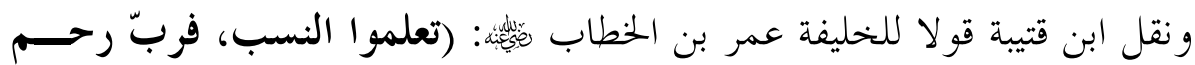

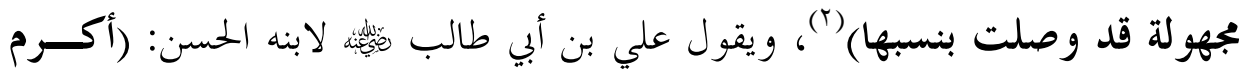

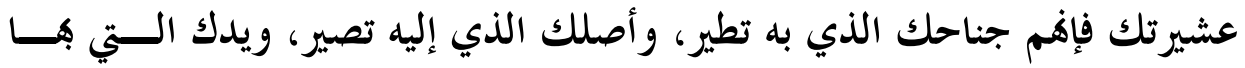
تصول) (r) كما كان لمعرفة الأَنسَاب في الإسلام أهميَّة من جوانب متعددة، منها في البحــالات

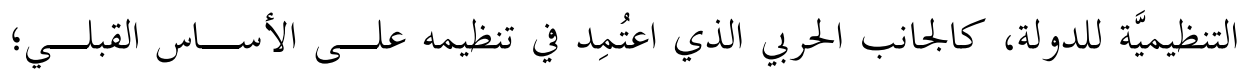

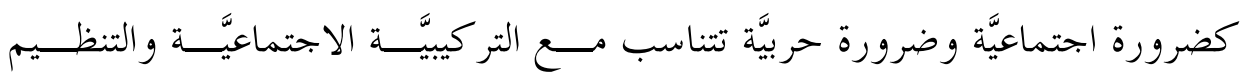
العسكري الحربي.

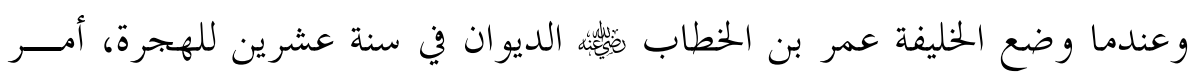

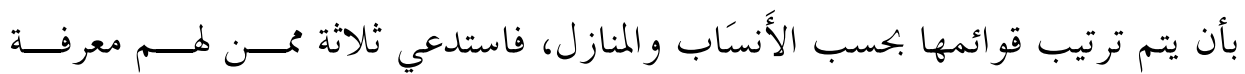

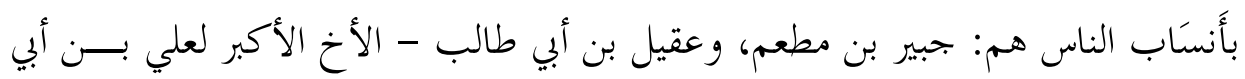
طالب، ومخرمة بن نوفل؛ فوضعوا الدواوين بحسب الأَنساب و المنازل.

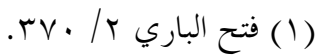

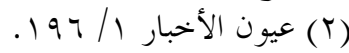

$$
\begin{aligned}
& \text { (r) عمدة الطالب ابن عنبة ص } 7 .
\end{aligned}
$$


أما الطريقة التي اتّبعها أصحاب الديوان في عهد عمر بن الخطاب تمثلت في تقسـيم العرب وتصنيفهم إلى صنفين: قحطانيين وعدنانيين، فالعدنانيون مقدّمون على غيرهم لظهور البي فيهم، ثم بعد ذلك يتم تصنيف العدنانيين إلى طبقتين: مضر، وهي المقدمة عندهم، وربيعة. و بلدورها مضر تعرّضت للتفكيك و التقسيم عندهم إلى بحموعتين هما: قريش، وغير قريش، فأعطوا لقريش الحقّ في الأفضلية والتقدم، ثم قسمت قريش أيضا

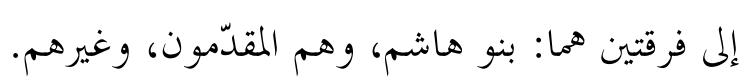

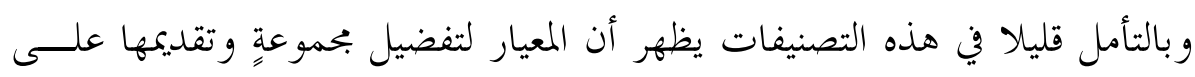

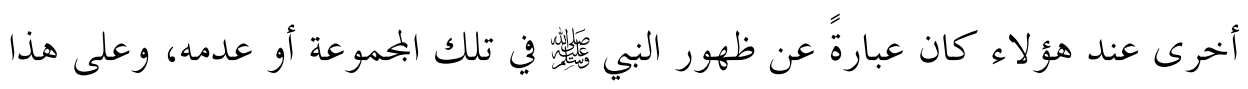

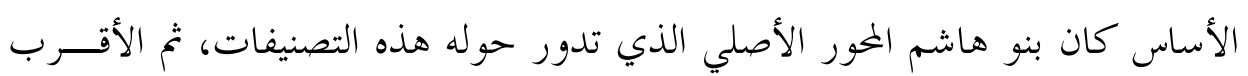

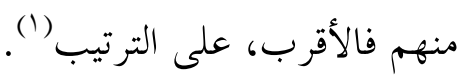
ولكن منذ بداية العصر الأموي ونتيجة اهتمام خلفاء بني أميَّة بالتاريخ والأَنستــاب

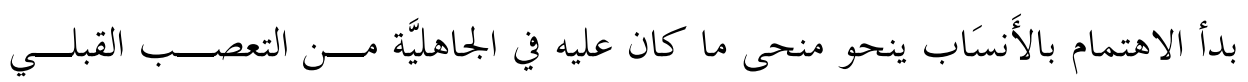
والأسري وظهرت كتب المثالب و المناقب.

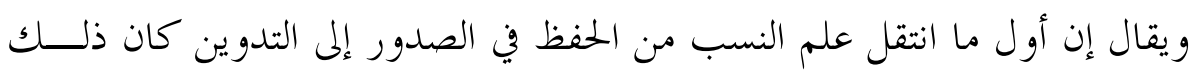

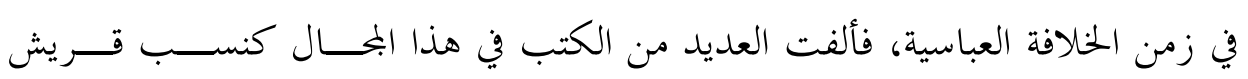

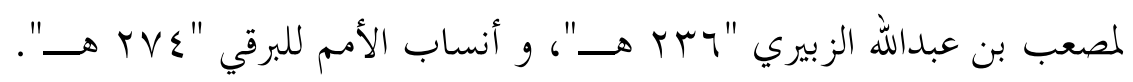
وقد تواتر عن علماء الأمة التأكيد على أهمية هذا العلم، وبسطوا القول في فضــله

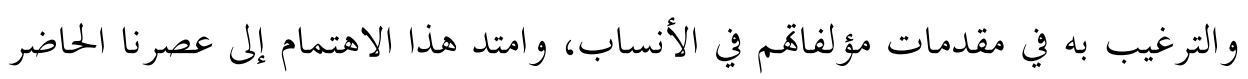


فألف فيه علماء كبار، أو قدموا لمؤلفات في الأنساب لغيرهـ (') وقســمت كتــبـ الأنساب إلى مبسوطات ومشجرات، فالمبسوط هو تسطير النسب على السطور، وفيه

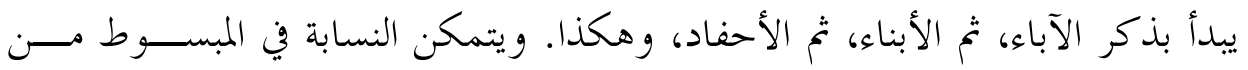
الإسهاب في ذكر أخبار الأســر وتاريخها. أما المشجر فهو ما أخذ هيئة الشجرة مــنـ

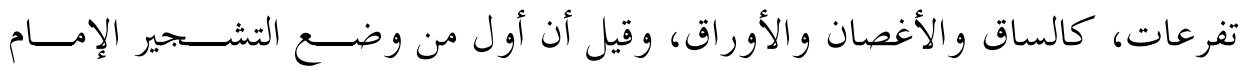

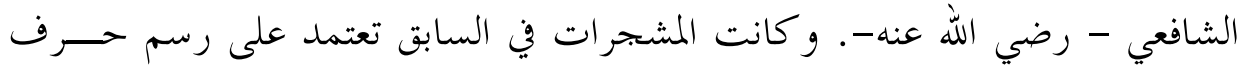

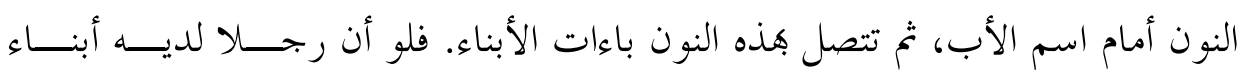
عديدون ذكر اسم كل منهم تخ لحق باسمه حرف الباء فقط، وهذا الباء يمد حتى يصل النون الموجودة أمام اسم الأب مشكلة بذلك كلمة "ابن"، ثم يلحق باسم الولد الآخر حرف الباء الذي يمد كذلك ليتصل بذات النون الموجودة أمام اسم الأب، وهكذا بقية

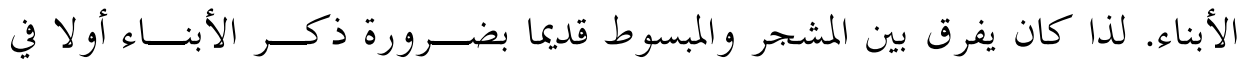
المشجرات؛ لإلحاق حرف الباء هـم، ثم يذكر الآباء ثم الأجداد.

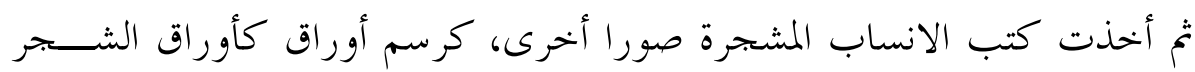
وتدوين الأسماء هـا، أو رسم حلقات أو خطوط تصل بين الأبناء والآباء مما لايســتلزم ذكر الأبناء أولا كما في المشجرات القديمة، وفيما بعد ظهرت وثائق نسب تخص كل أسرة بذاها، فتقسم ذات الوثيقة إلى ديباجة، يحمد الله فيها، ويصلى على البي لئل يسرد النسب مبسوطا، ثم يلحق به المشجر، وتزان الوثيقة بتواقيع وتصديقات النسابين

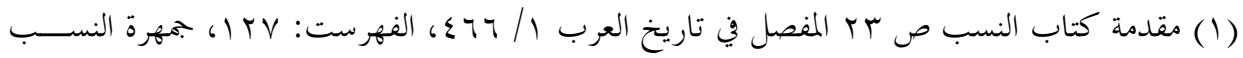

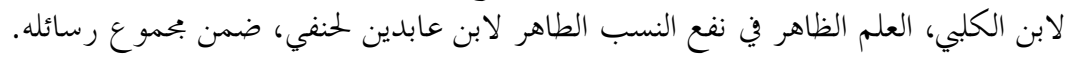


و العلماء و الأمراء و الوجهاء. ثم بدأت تدخل أفكار غريبة على الأمة الإسلاميَّة أَّّرت على وحدةها، فبدأ الصراع

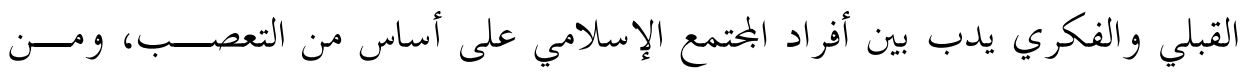

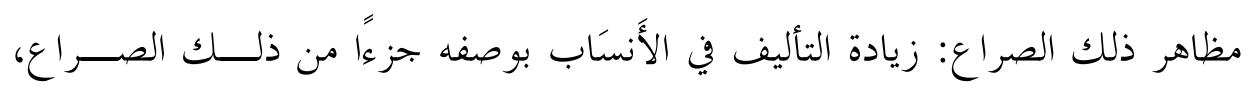

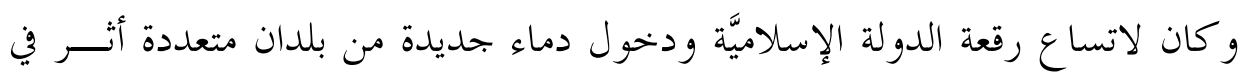

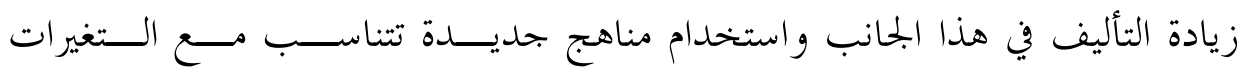
الاجتماعية، حيث صار مفهوم الأَنسَاب يطلق على النَسَب إما لصفة علميَّة، أو مهنيَّة،

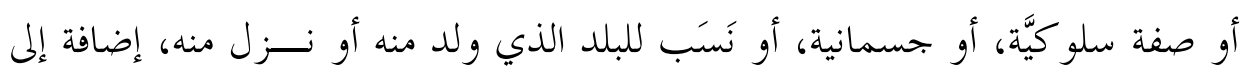

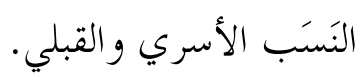

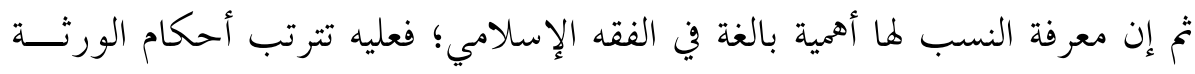
فيحجب بعضهم بعضا، وأحكام الأولياء في النكاح فيقدم بعضهم على بعض، وأحكام العاقلة في الدية حتى تضرب الدية على بعض العصبة دون بعض. وقد تحدث القلقشندي عن أهميَّة علم الأنساب ومسيس الحاجة إليه فقال: لا خفاء

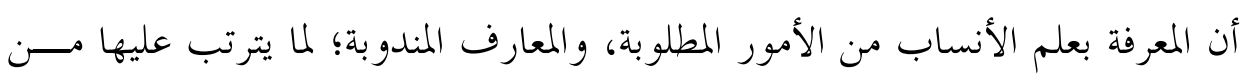
الأحكام الشرعية، والمعالم الدينية، فقد وردت الشريعة المطهرة باعتبارها في مواضع:

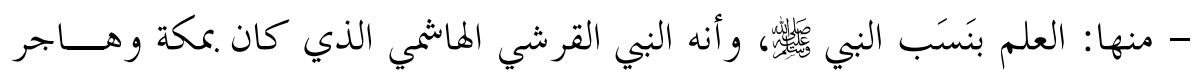
منها إلى المدينة؛ فإنه لا بد لصحة الإيمان من معرفة ذلك، ولا يعذر مسلم في الجههــل به، و ناهيك بذلك.

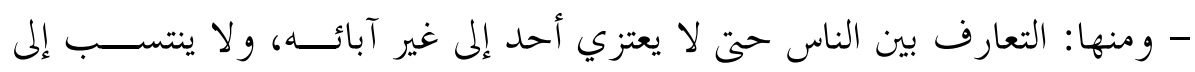




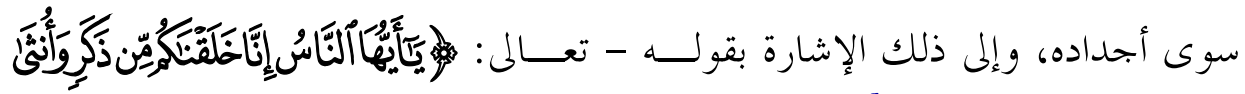

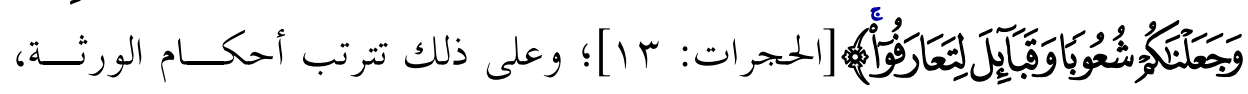

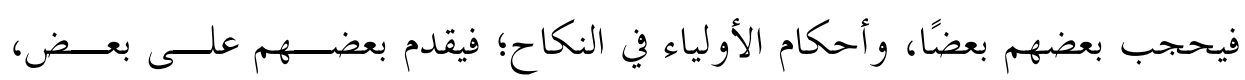

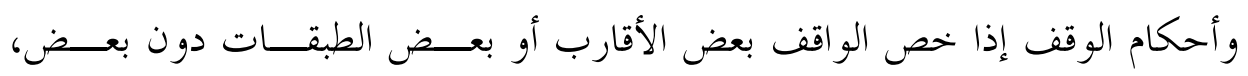

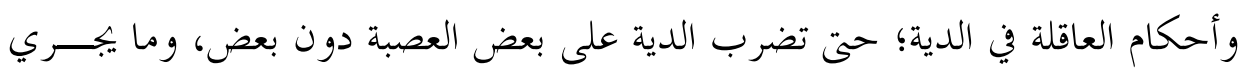
بحرى ذلك، فلو لا معرفة الأنساب لفات إدراك هذه الأمور وتعذر الوصول إليها.

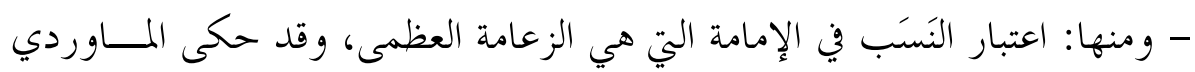

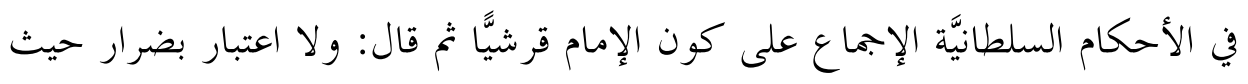

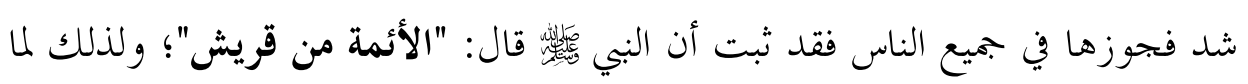

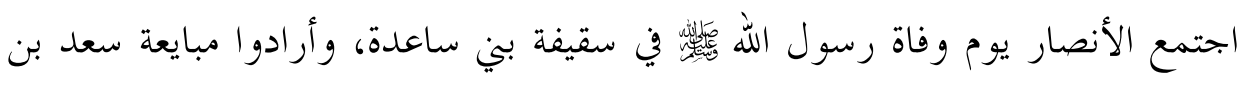

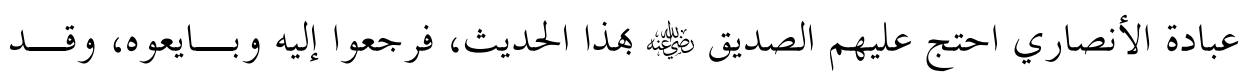

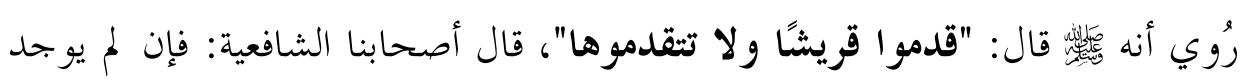

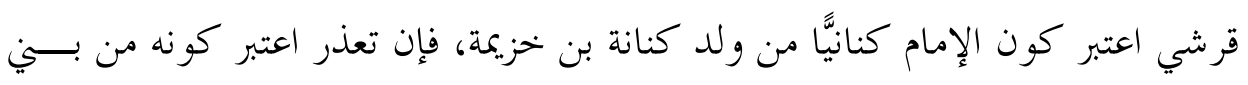

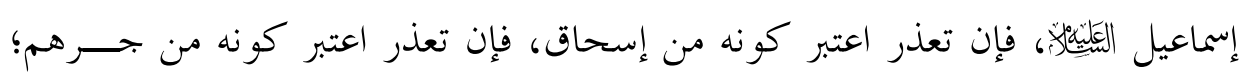

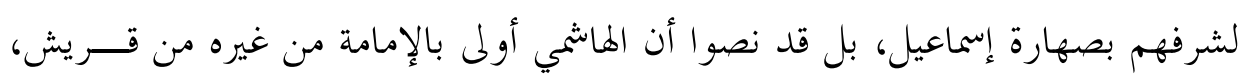

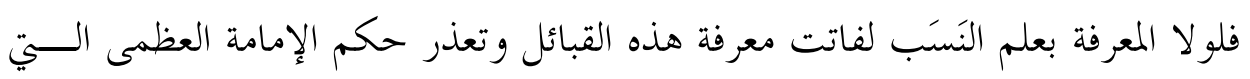

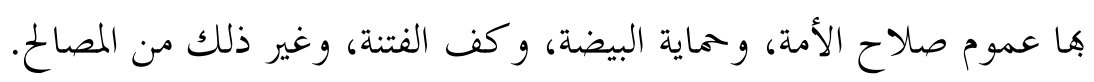

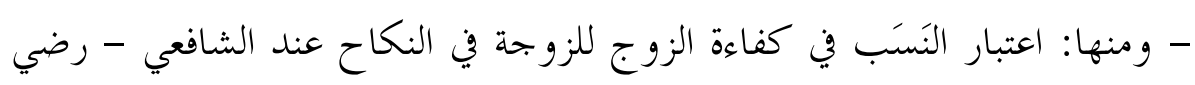

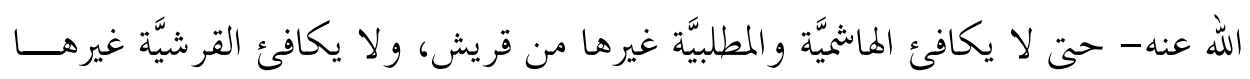


من العرب ممن ليس بقرشي، وفي الكنانيَّة وجهان أصحُهُما أنه لا يكافئها غيرها مـــن

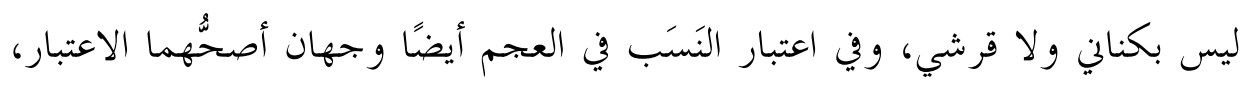

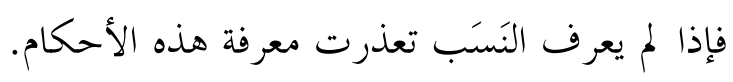

- و ونها: مراعاة النَسَب الشريف في المرأة المنكوحة، فقد ثبت في الصحيح أن النبي ئل الحسب، وهو الشرف في الآباء.

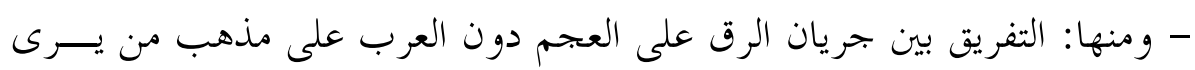

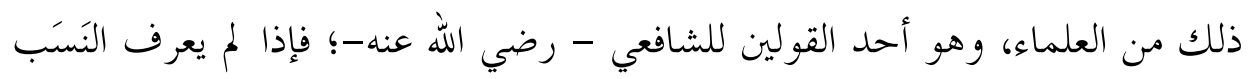
تعذر عليه ذلك، إلى غير ذلك من الأحكام الجارية هذا البحرى(').

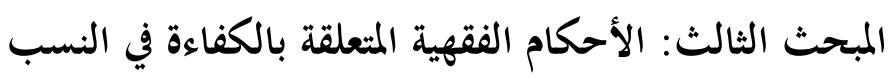

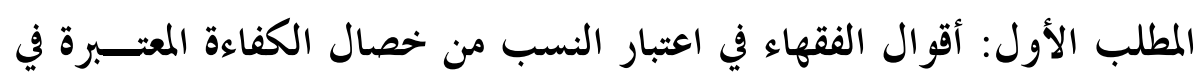
النكاح اختلف الفقهاء في اعتبار النسب من خصال الكفاءة المعتبرة في النكاح على قولين:

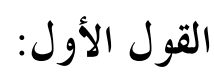

النسب من الخصال المعتبرة في الكفاءة، والتي تعتبر شرطا في عقد النكاح، وهو قول

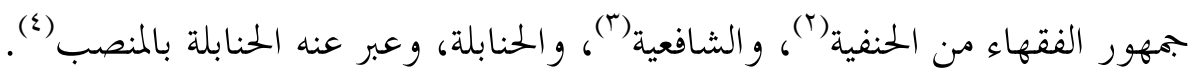

$$
\begin{aligned}
& \text { (1) هاية الأرب في معرفة أنساب العرب للقلقشندي. }
\end{aligned}
$$

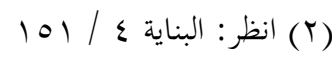

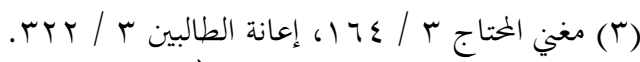

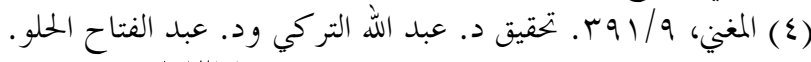

$$
\begin{aligned}
& \text { - ITV_ }
\end{aligned}
$$




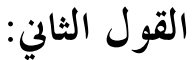

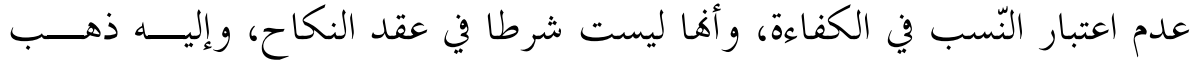
مالك (')، وسفيان الثوري (r).

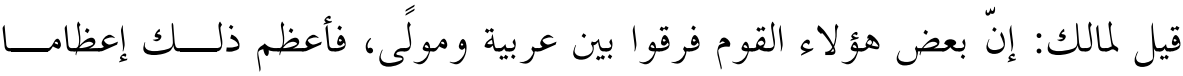

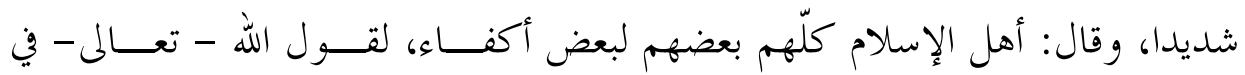

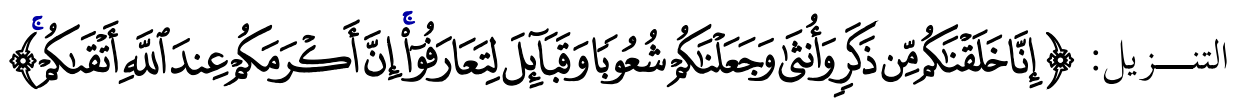
[الحجرات: r 1 ]، و كان سفيان الثوريّ يقول: لا تعتبر الكفاءة في النّسب؛ لأنّ الناس

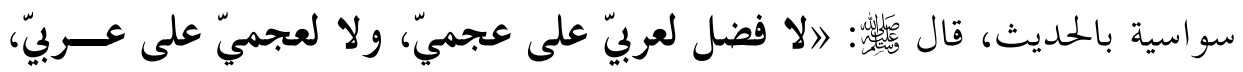

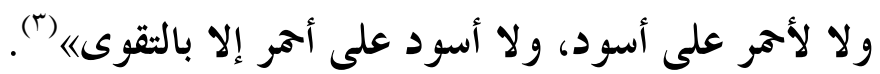

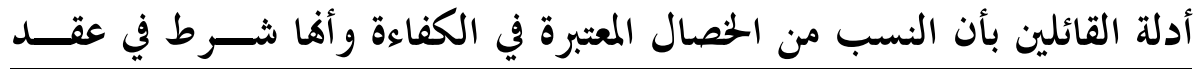
النكاح:

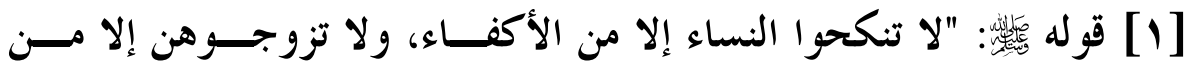
الأولياء، ولا مهر دون عشرة دراهم"(£).

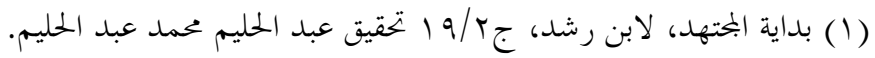

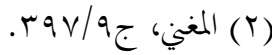
(Y)

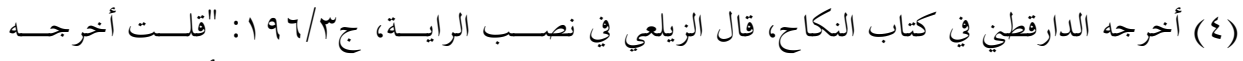

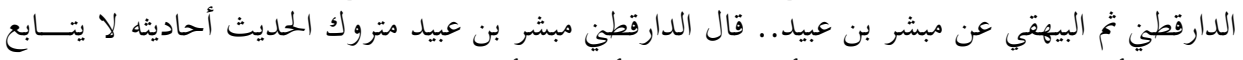

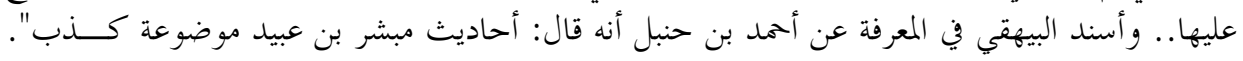

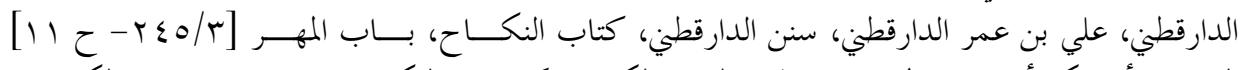

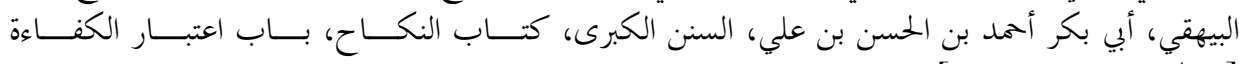
[1 [1 . 
وجه الدلالة: هىى الرسول أن تزوج المرأة من غير كفء مما يـــل علــى اعتبــار

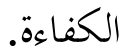

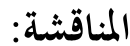

هذا الحديث أخرجه البيهقي والدار قطني كما سبق، وقد أعلّه الزيلعي - رحمه الله - في نصب الراية فقال: "قال الدارقطني: ولكنّ راوي الحديث: مبشر بن عبيد، وهو

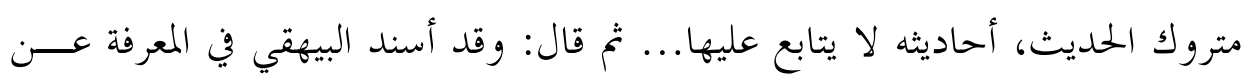

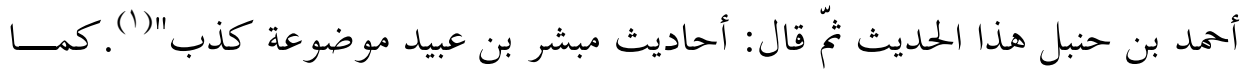

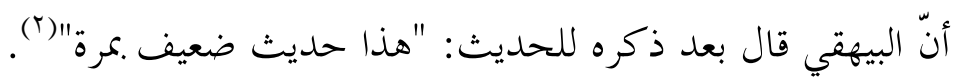

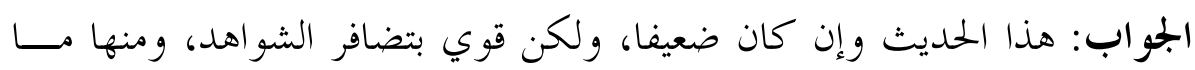

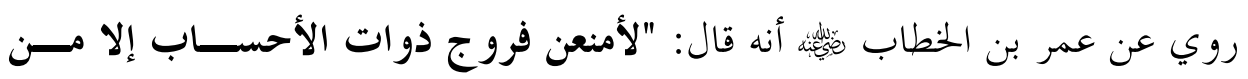

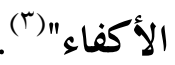

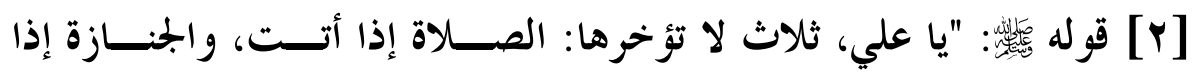

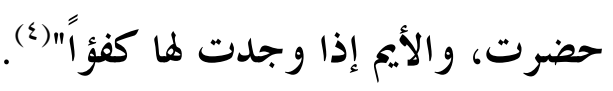

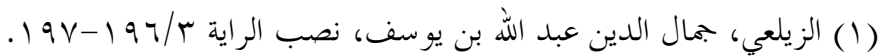

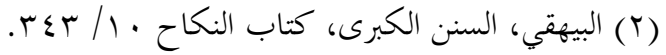

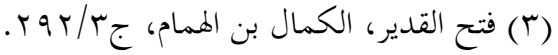

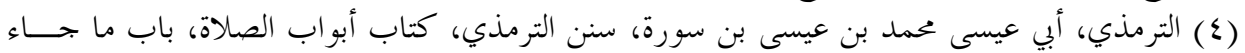

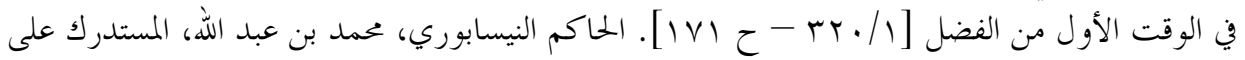

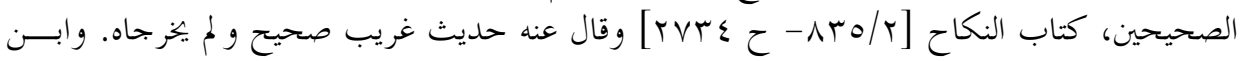

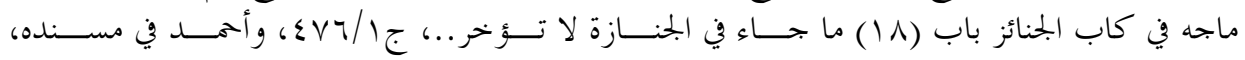

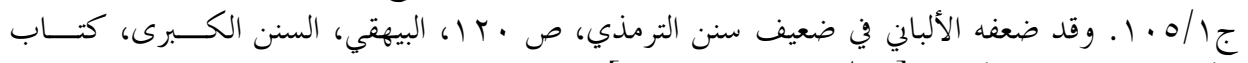

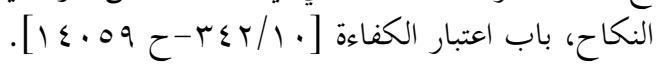




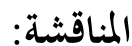

هذا الحديث رواه الترمذي في الصلاة، ثمّ قال: حديث غريب، وما أرى إســــاده

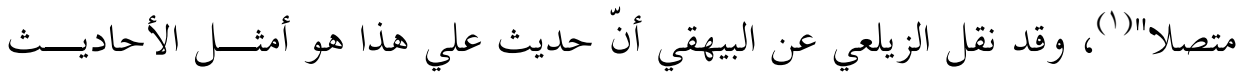

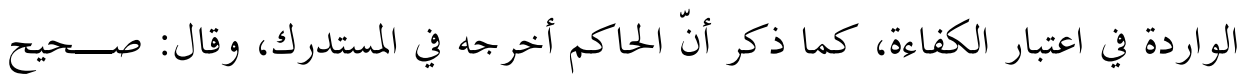

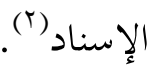

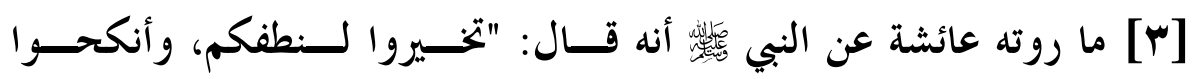

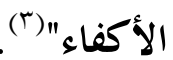

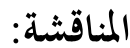

استدل به ابن الجحوزي - رحمه الله- في تحقيق الخحلاف على اشتراط الكفاءة، وأورد

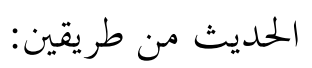

- الأول: بلفظ: "تخيرو النطفكم، ولا تضعوها إلاّة في الأكفاء".

- و الثاني: بلفظ: "تخيرو النطفكم، و انكحوا الأكفاء، وأنكحو ا إليهم" .

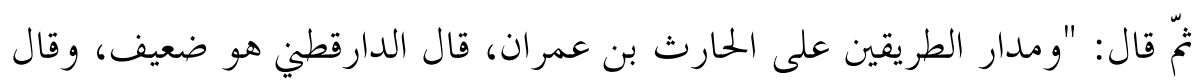

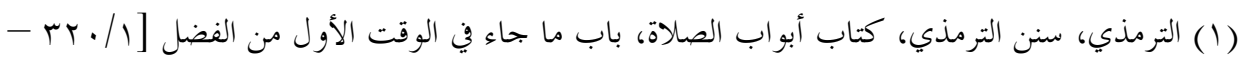
. [IVI

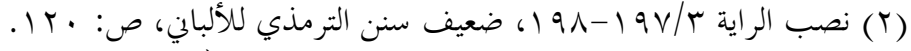

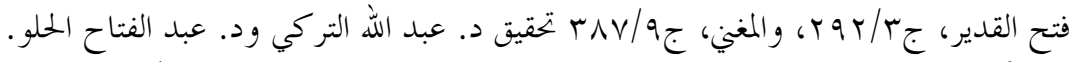

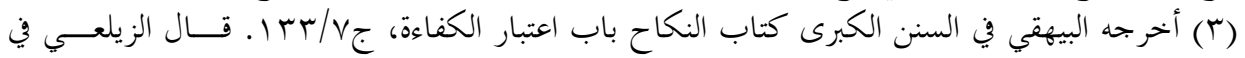

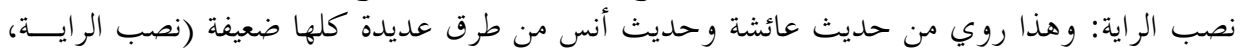

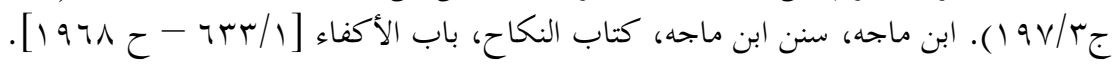
$-1 \varepsilon$. 
ابن حبّان: كان يضع الحديث على الثقات"(1)، و قد ذكر في نصب الر اية أنّ الطـــرق

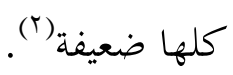

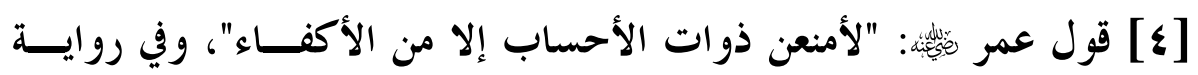

قلت: وما الأكفاء ؟ قال: في الأحساب(r).

[0] قصة سلمان مع جرير بن عبد الله عندما قدمه جرير في الصــالاة فــامتنع سلمان وقال: "إنكم معشر العرب لا يتقـــدم علــــكم في صــالاتكم، و لا تــــكح

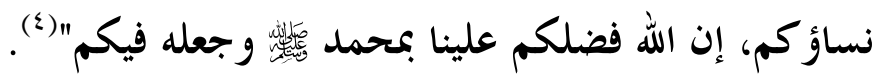

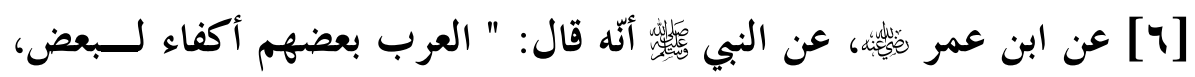

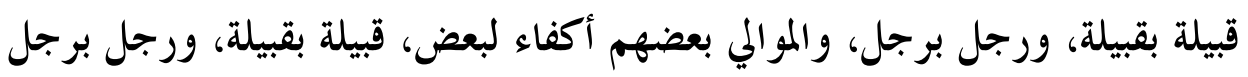

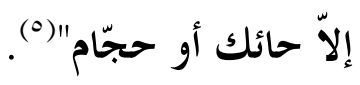

المناقشة: هذا الحديث تحدّث العلماء فيه: - فذكر الشوكاني في نيل الأوطار أنّ في إسناده رجلا بجهولا، وهو الراوي له له عن

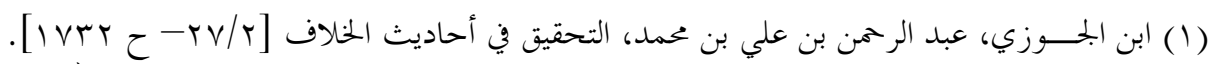

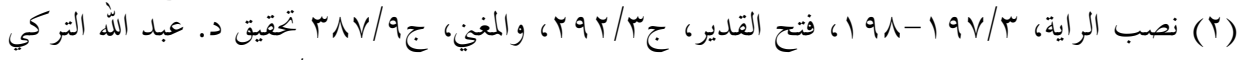

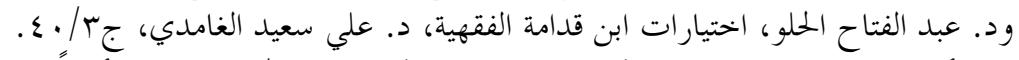

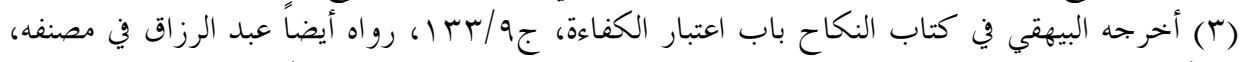

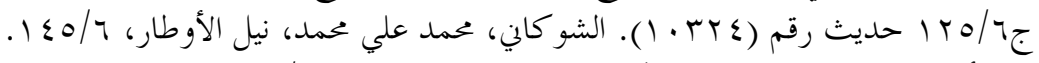

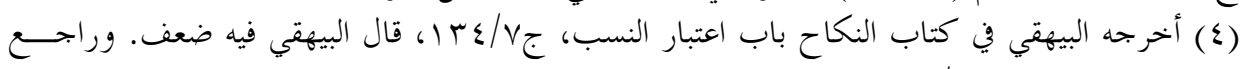

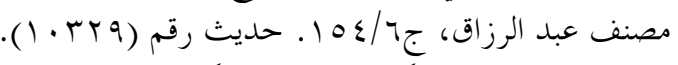

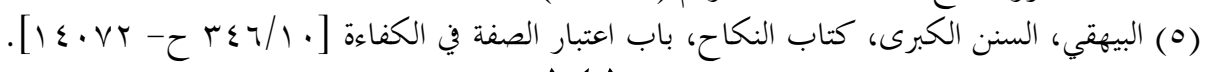


ابن جريج، فقال: "وقد سأل ابن أبي حاتم أباه عن هذا الحديث فقـــال: هذا كذب لا

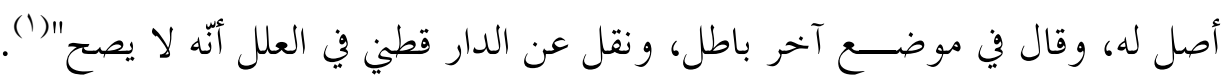

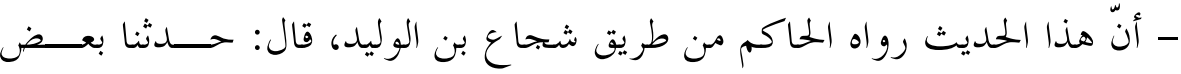

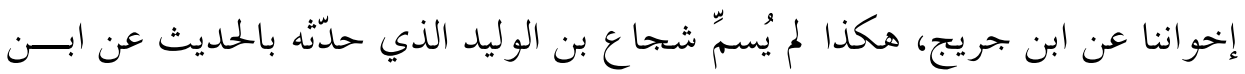

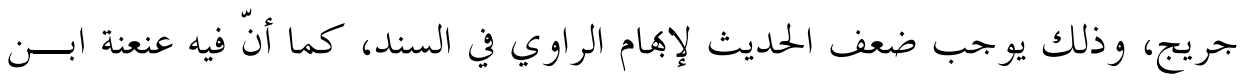
جريج و هو مدلّس. الجحواب: إن كان في الحديث ضعف فئنّه يتقوى بكثرة الأحاديسـث الأخهـرى في

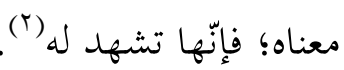
-و كذا فقد عَمِلَ الإمام أحمد بن حنبل هَذا الحلديث على الرغم مــن ضعفـــــه، فجــاء في كشاف القناع قوله: "وروي في حديث: "العرب بعضهم لبعض أكفاء إلاّ حائكا أو حجّاما"، قيل لأحمد: كيف تأخذ به و أنت تضعَّه؟ قال: العمل عليه، يعني:

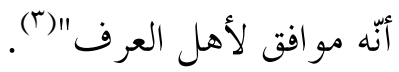

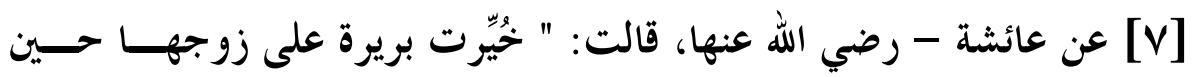

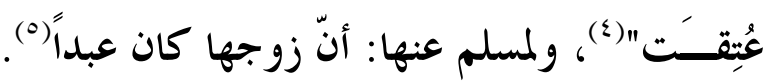

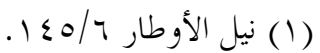

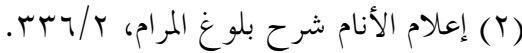

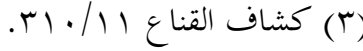

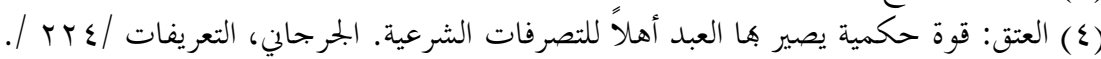

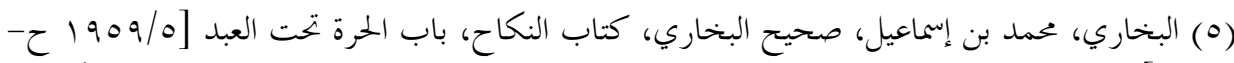

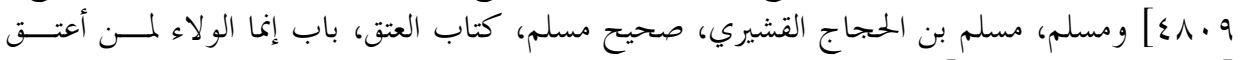
[10. $[2-11 \leqslant r / r]$ 


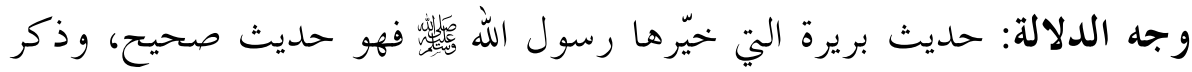

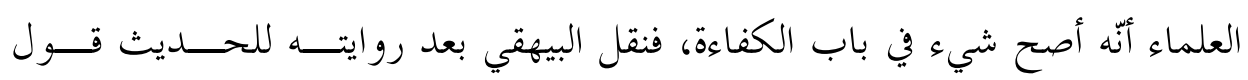
الثافعي: "أصل الكفاءة مستنبط من حديث بريرة، كان زوجها غير كفء لها فخيّرها

(1) (1) بول الله

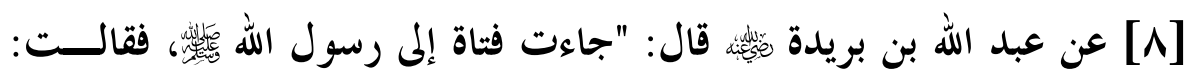

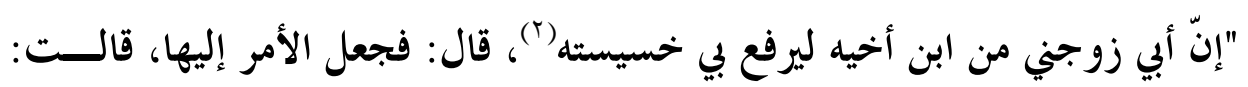

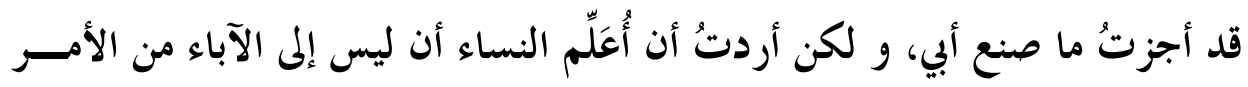
شيئا"(")

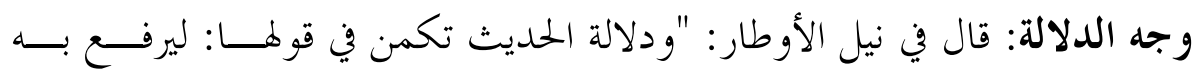

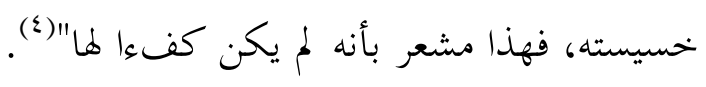

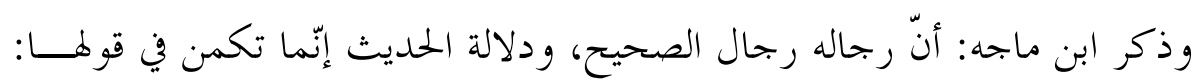

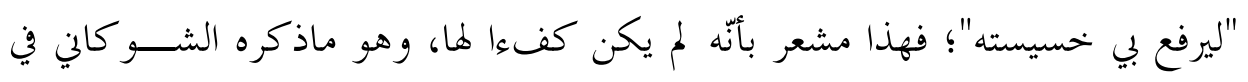
نيل الأوطار (ن)

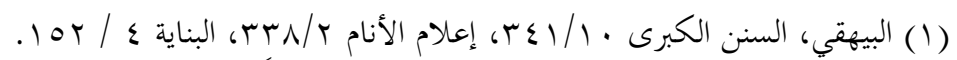

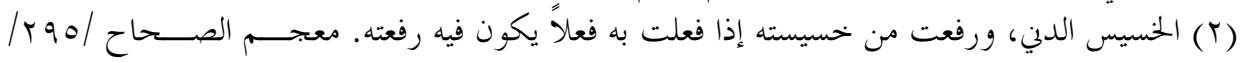

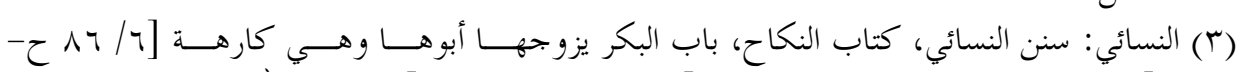

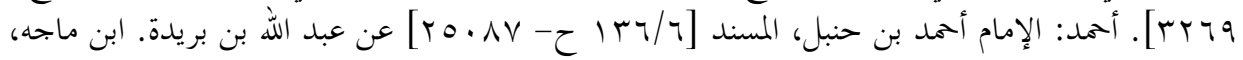

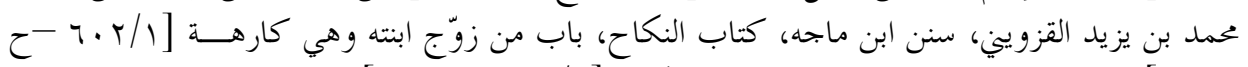

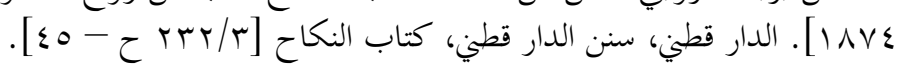

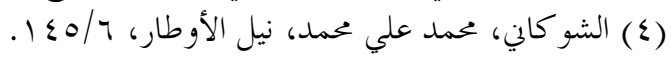
$-1 \leqslant \Gamma_{-}$ 


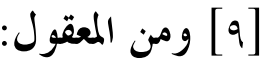

[1] أن انتظام المصالح ودوام العشرة و الاستقرار بين الزوجين لا يكون عسـادة إلا

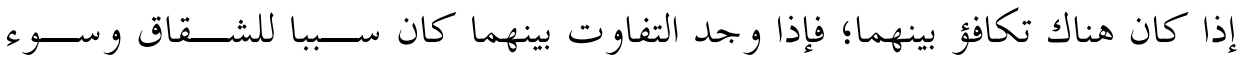

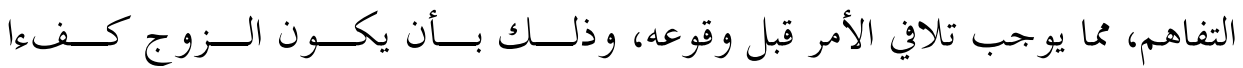

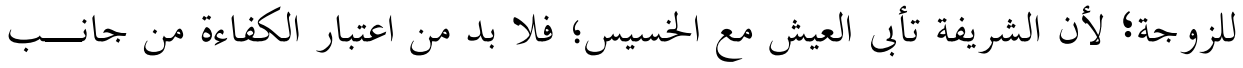

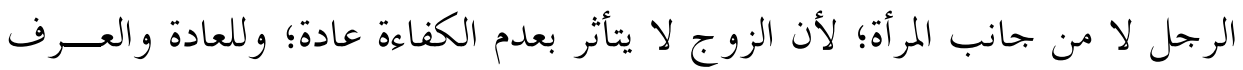

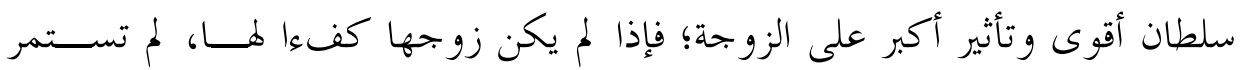

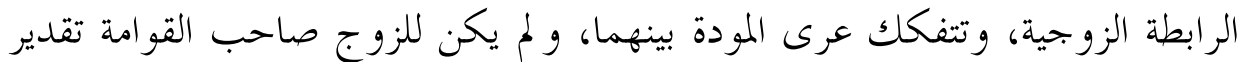

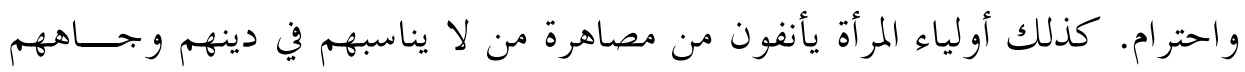

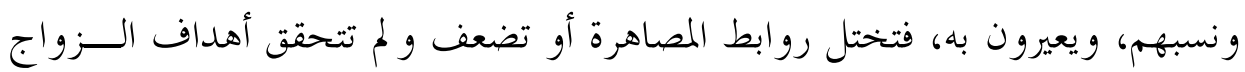

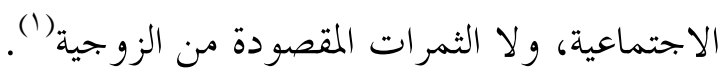

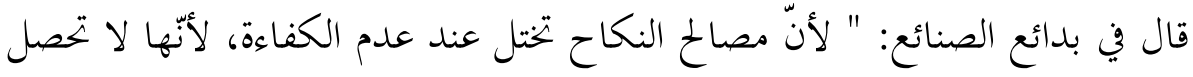

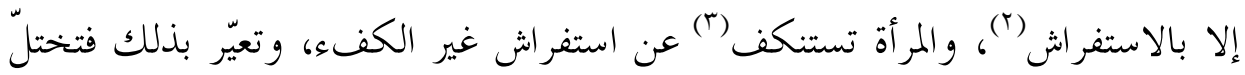

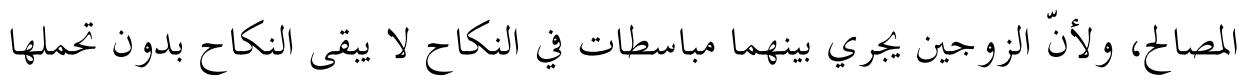

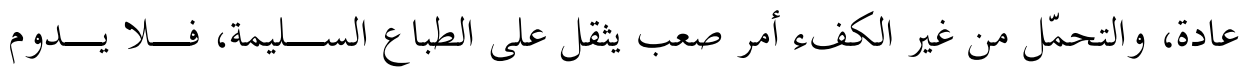

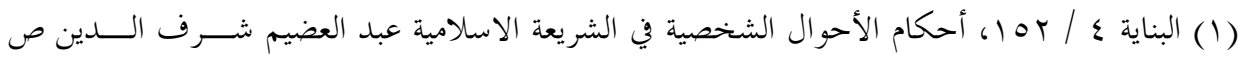

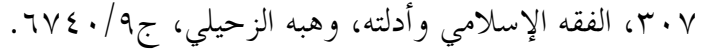

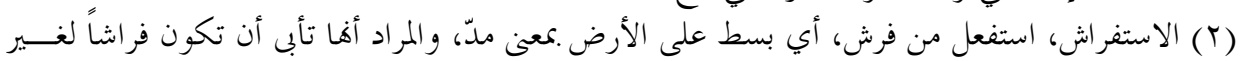

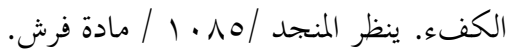

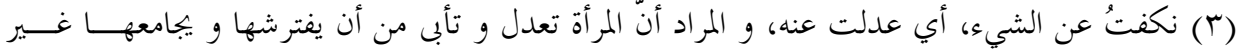

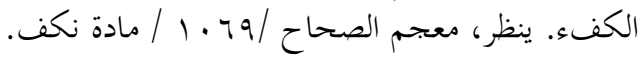




\section{النكاح مع عدم الكفاءة؛ فلزم اعتبارها"(1) .}

[Y] و وألّ العرب يعتمدون الكفاءة في النّسب، ويتفاخرون برفعة النّسب، ويأنفون

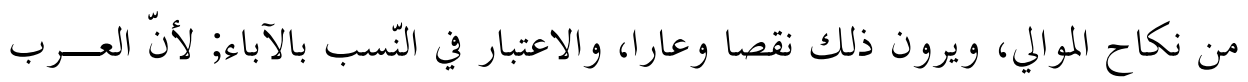

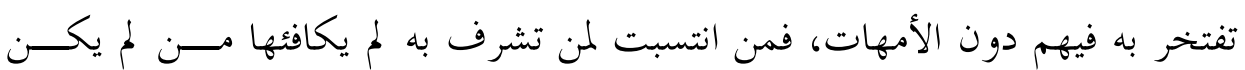

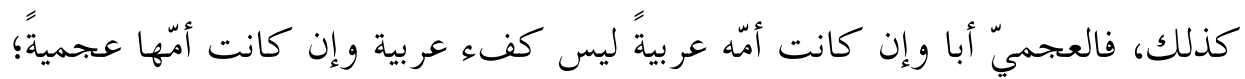

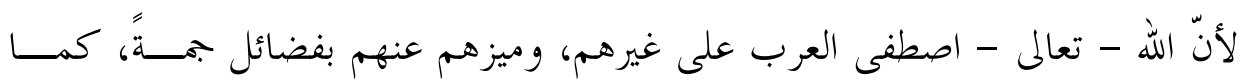
صحت به الأحاديث.

[r] إن اعتبار الكفاءة من جانب الرجل لأن بالكفاءة تكون القوامة حقه، ويكون الزوج أهلا لها وقادرا على القيام هـا.

أدلة اقائلين بعدم اعتبار النّسب في الكفاءة وأفا ليست شرطا في عقد النكاح:

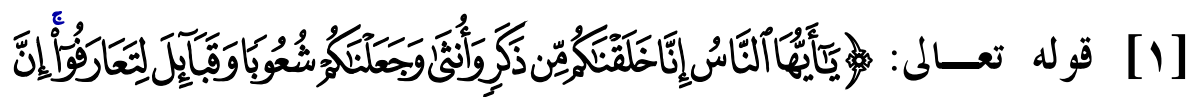

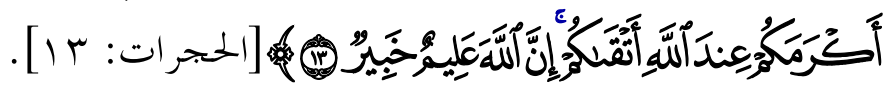
وجه الدلالة: تدل الآية أن المعيار هو التقوى، وليس شرط الكفاءة. قال ابن العربي: وهذه الآية استدل مالك - رحمه الله - بأن الكفاءة في الدين(؟).

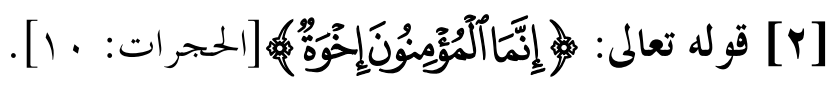

وجه الدلالة: تدل على المساواة المطلقة، وبالتالي على عدم اشتراط الكفاءة. 


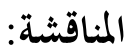

الآيات التي استدلو إها والتي تنفي التفاضل بين الناس إنما المر اد بها أحكام الآخـــرة،

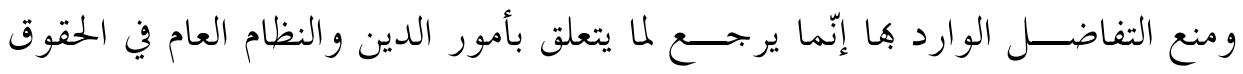
والواجبات، أمّا مايتعلق بالصفات الشخصية فالنّاس يتفاوتون بلا شك بك (1).

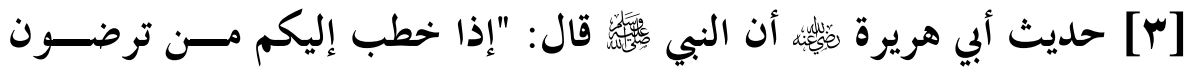
دينه وخلقه فزوجوه إلا تفعلوه تكن فتنة في الأرض وفساد كبير"(؟).

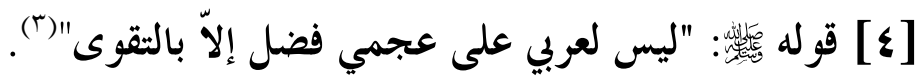

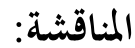

في بدائع الصنائع حيث قال: "وأمّا الحلديث ليس لعربي على عجمي... فالمراد بــــ

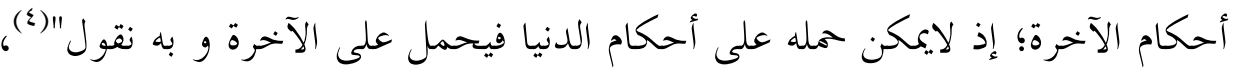

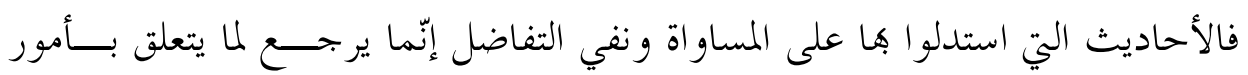

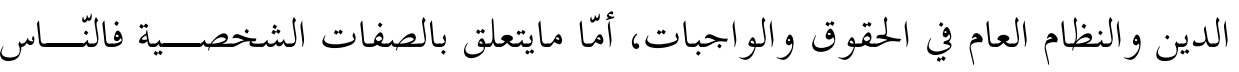
يتفاوتون (0) - (ن)

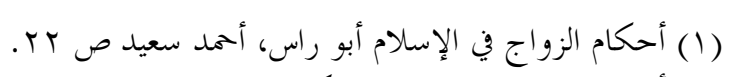

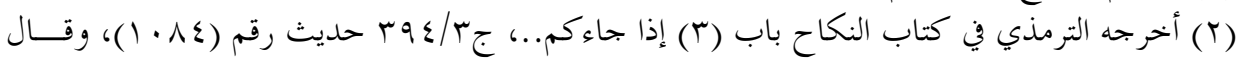

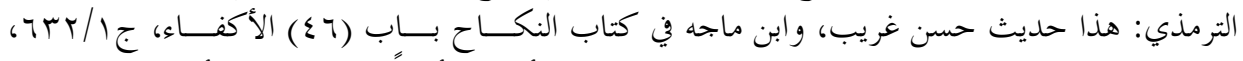

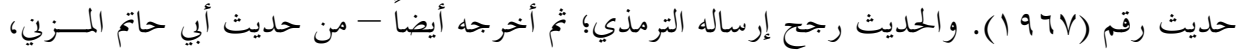

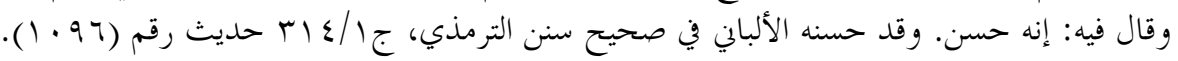

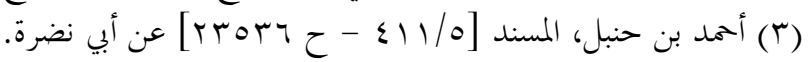

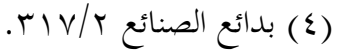

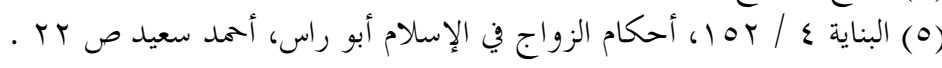




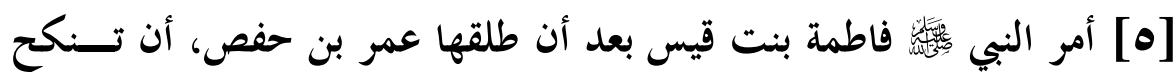

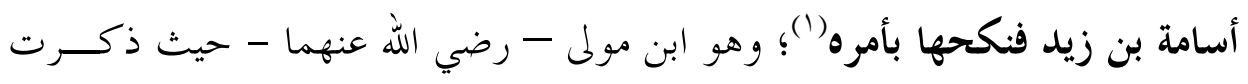

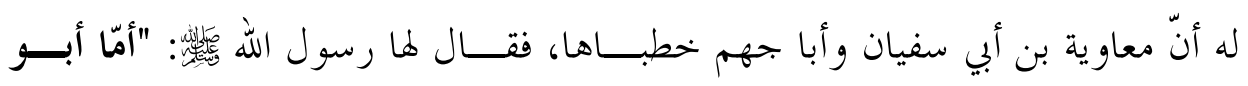

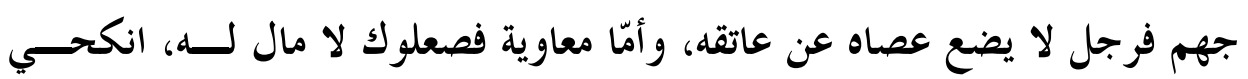
(ז)" أسامة (r)

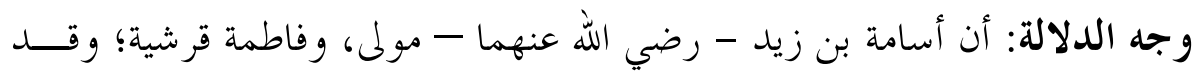

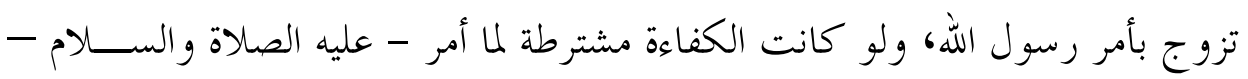
بذلك (")

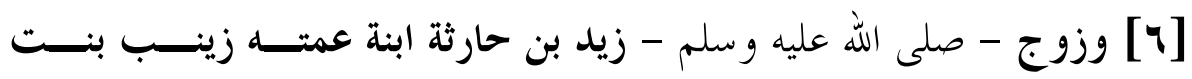

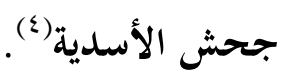
وجه الدلالة:

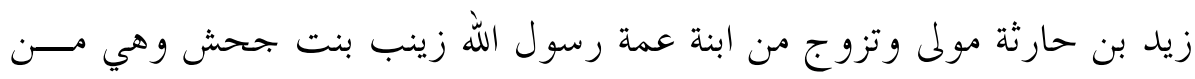

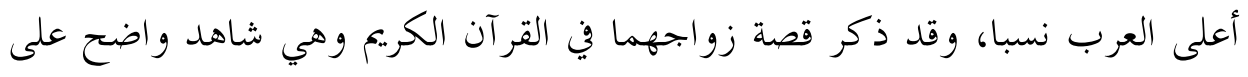

(1) انظر: صحيح مسلم كتاب الطلاق باب (1) المطلقة ثلاثاً لا نفقة لما، جr/\& 111، حسـديث رقــ

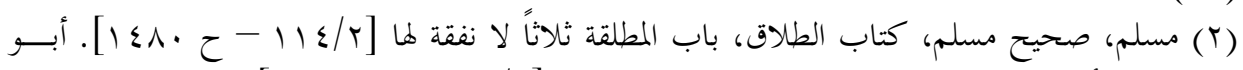

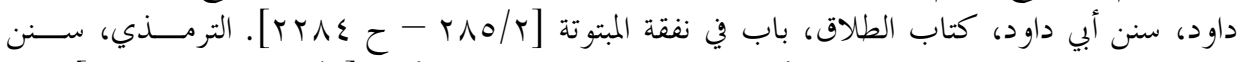

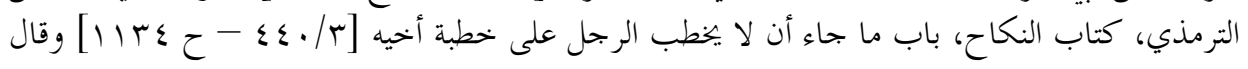
$-1 \leq V_{-}$ 
علدم اشتر اط الكفاءة)' (')

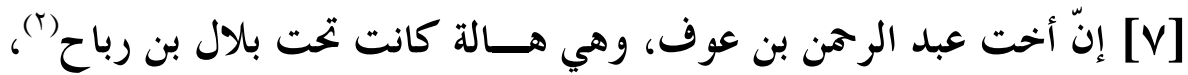

وبالال مولى للصّدّيق (r).

وجه الدلالة: أمر البي بـ

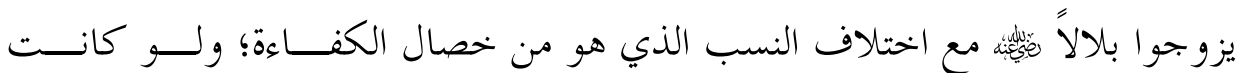

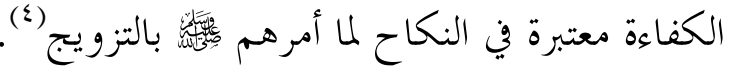

[^] ما روي عن عائشة -رضي الله عنها-: "أن أبا حذيفة بن عتبة بن ربيعــة

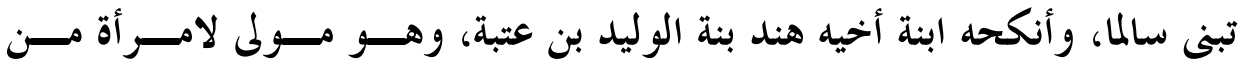

(الأنصار "(0)

قال البيهقي بعد ذكر الحلديث: "فهزه قرشية من بني عبد شمس بن عبـــــ منــــاف

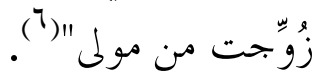

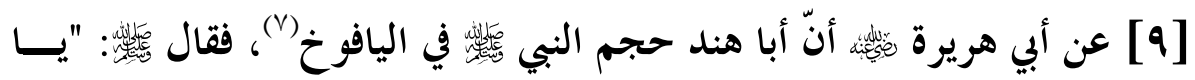

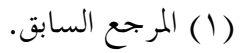

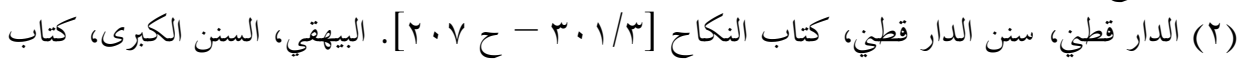

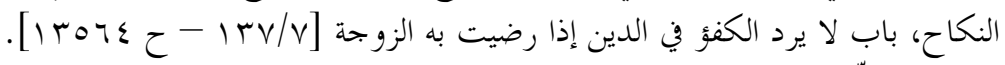

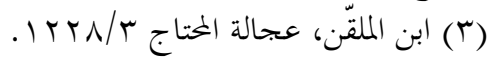

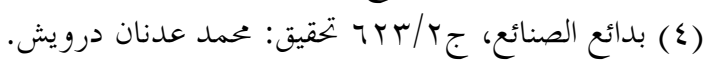

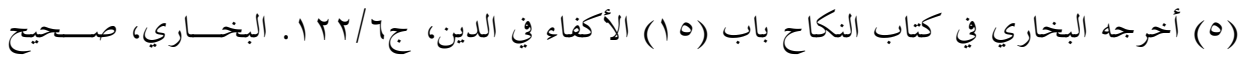

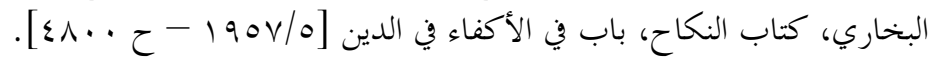

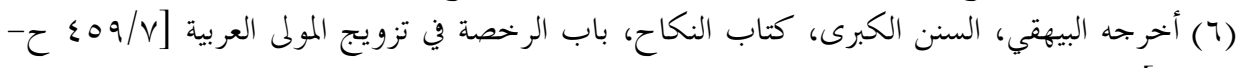

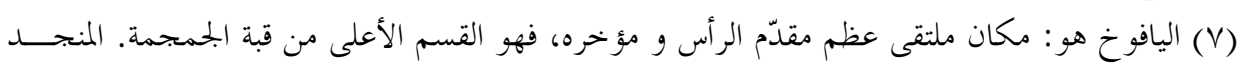
/ مادة يفخ. 


\section{بني بياضة، أنكحوا أبا هند وانكحوا إليه"، و كان حجّاماً (1).}

المناقشة:

أن الأحاديث الواردة في زواج العديد من الصحابة من نساء لسنَ بكفــــؤ لـــنّ،

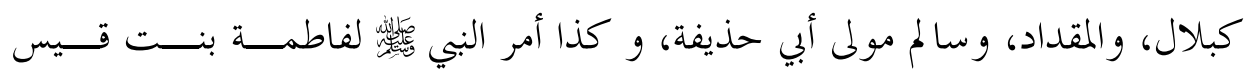

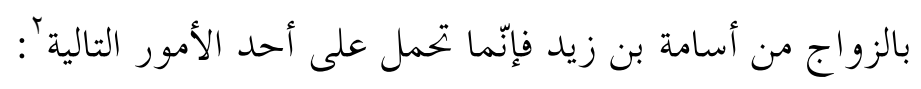

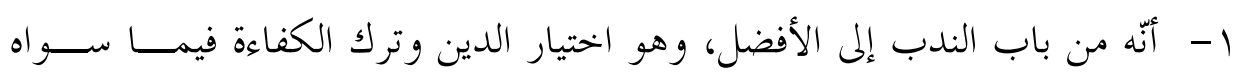
و الاقتصار عليه، وهذا لا يمنع جواز الامتناع إن لم تتوفر باقي خصال الكفاءة.

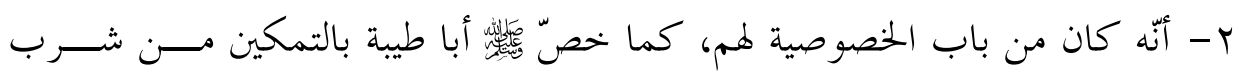
دمه - صلى الله عليه وسلم، وخصّ خزيمة بقبول شهادته وحده، ونهو ذلك.

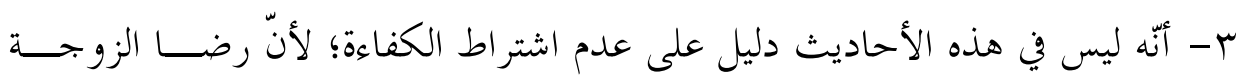

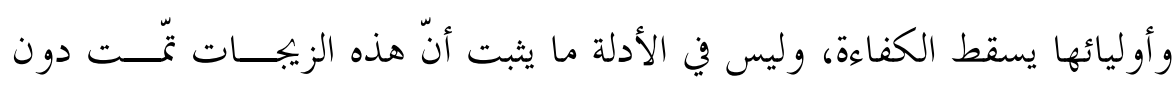
مو افقة الزوجة وأوليائها حتى نستدل هـا على عدم اشتر اط الكفاءة.

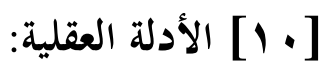

[1] القياس في عدم اشتراط الكفاءة في النكاح على عدم اشتراطها في الجنايــات،

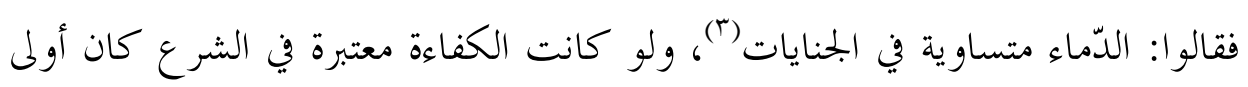

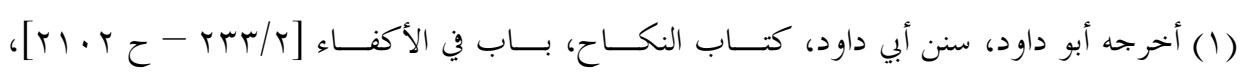

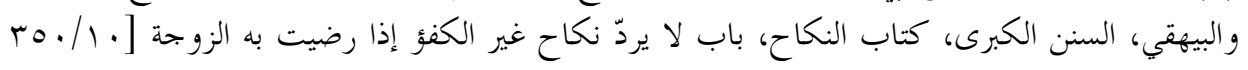

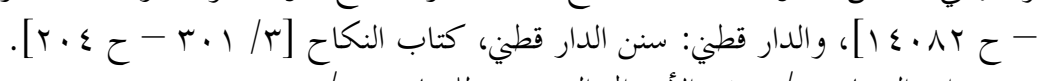

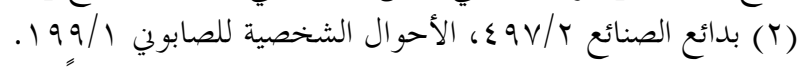

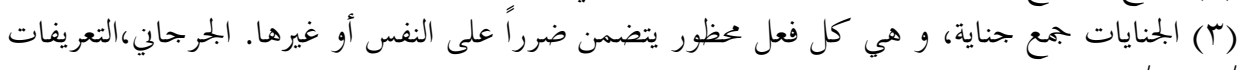
/ / | 
الأبواب بالاعتبار باب الدماء؛ لأنه يحتاط فيه ما لا يحتاط في سائر الأبواب؛ ومع هذا

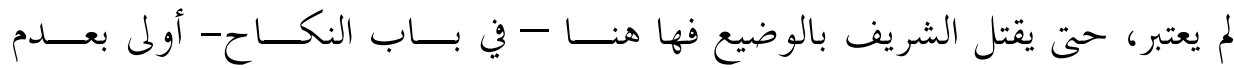
(') الاعتبار (1')

\section{المناقشة:}

أن قياسهم الزواج على مسائل الجنايات والقصاص فهو غير سديد؛ لأنّ القصــاص

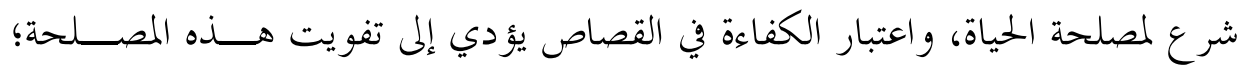

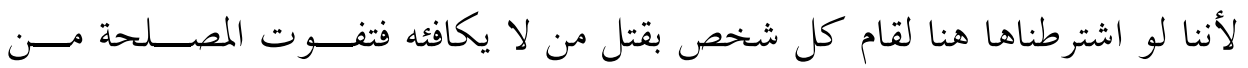
القصاص و هي حفظ الحياة. وأما اشتراط الكفاءة في عقد النكاح ففيه حفظ لمصلحة

$$
\text { عقد النكاح المطلوبة شرعالَ(ا). }
$$

مما سبق يتبين أن الأدلة النقلية لا تخلو عن مقال، و كذلك الأدلة العقلية لم تسلم من

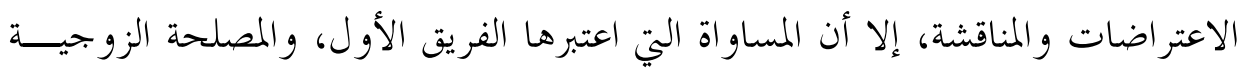
التي اعتبرها الفريق الثاني والتي تكمن فيها الألفة والمودة بين الزوجين و التي لا تحصـل التصل إلا بين المتكافئين لو نظرنا إليها لترجح قول القائلين بأن الكفاءة شرط في عقد النكاح،

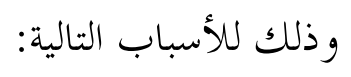

ا - أنّ المصلحة تدعونا إلى اشتراط الكفاءة، كما ذكره الكاســـاني؛ وذذلــك لأنّ مصالح النكاح تختل عند عدم الكفاءة، و هذا أمر واقع ملموس في زماننا هذا، حيــث إن

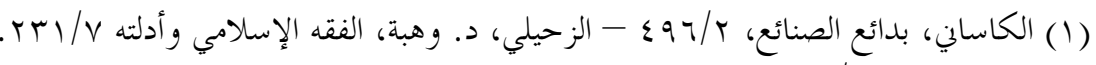

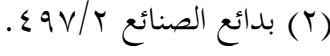


خفَّ الوازع الديني والتقوى عند كثير من الناس، ومال الناس بحيــاقم إلى الجو انـــبـ المادية؛ فالملاحظ أنّ الحياة الزوجية مع وجود الكفاءة بين الزوجين غالبا ما تكون أنجح

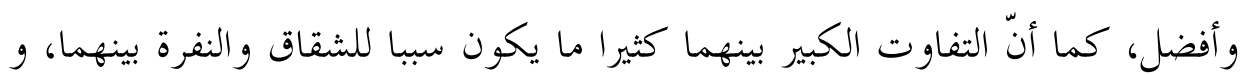

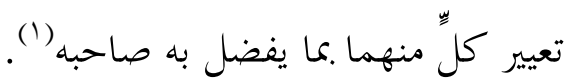
يقول ابن مازه في المخيط البرهاني:

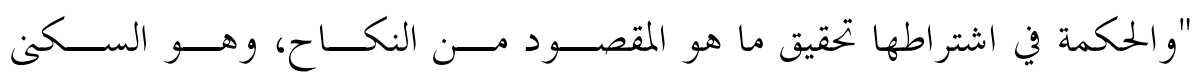
والازدواج" (r) (r) (ب)

r - تعدد الأدلة التي استندوا إليها، وهي وإن كانت ضعيفة إلاّ أنّ ضعفها يتقوى بتعددها، مما يرجح قبول المعنى الذي وردت به، وهو اشتراط الكفاءة، وفي هذا يقول

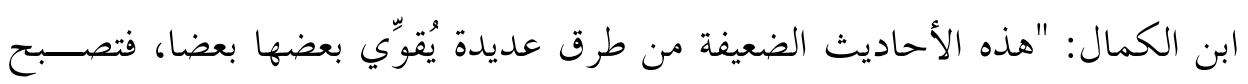

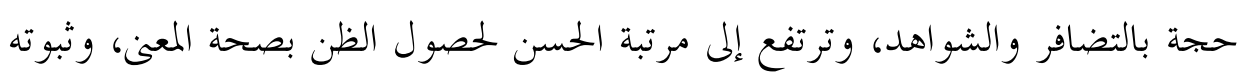
عنه ب- ورود حديث بريرة في الباب، وهو حديث صحيح يشهد لاشتراط الكفـــاءة،

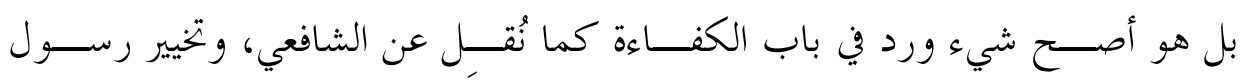

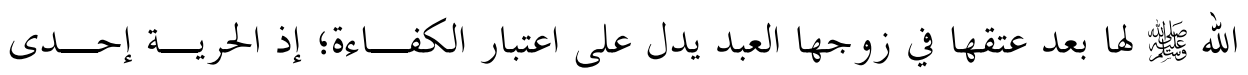
خصالما (\&)

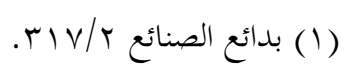

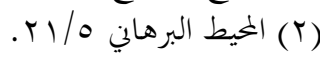

$$
\begin{aligned}
& \text { (Y) }
\end{aligned}
$$

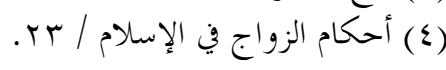


ولكن الأولى بالمسلم اختيار من يرضاه ممن لا يلحقه بمناسبته ومصاهرته عيــب أو

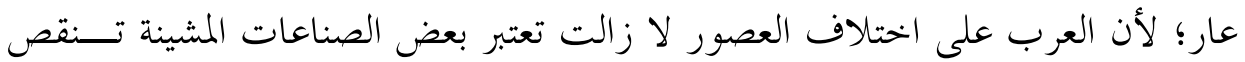
من شأن صانعها، وإن لم يكن لذلك أصل صحيح إلا أن الأولى تحنيب الأولاد العسـار

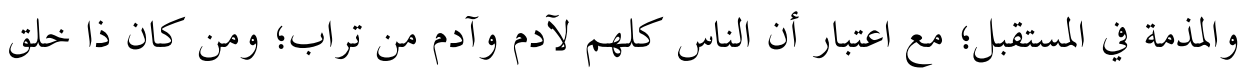
ودين فهذا الحسب الرفيع؛ لكن تراعى عادات الناس بقدر الإمكان؛ فالمتأمل في كلام

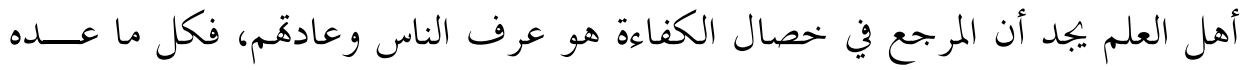

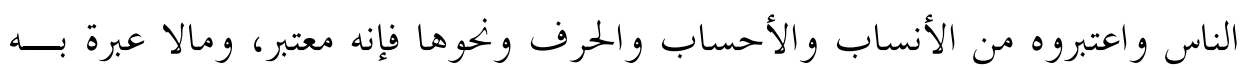
فإنه غير معتبر.

\section{- أثر العرف في اعتبار خصال الكفاءة:}

لــــــانت كانت الكفاءة من المواضيع التي تعتمد اعتمادا كبيرا على العرف كما ترجح

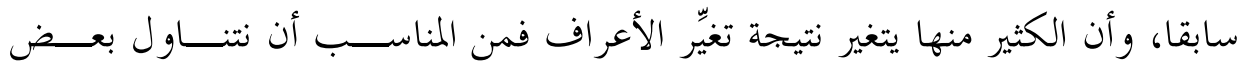
الجحوانب المتعلقة بالعرف ذات التأثير المباشر في ضبط أثره في الكفاءة. إن اختلاف أئمة المذاهب حول خصال الكفاءة، بل اختلاف أئمة المذهب الو احد حول هذه الخصال دليل على أن مايعتبر من الكفاءة هي مسألة نسبية مختلف عليهــا، يعود تقديرها إلى طبيعة الزمان و المكان. و العُرف - في اللغة: ما تعارف عليه الناس في عاداتم ومعاملاهم.

$$
\text { و والعُرف: المعروف (1). }
$$

وفي الاصطلاح: هو ما استقر في النفوس من جهة العقول، وتلقته الطباع السـليمة

$$
\text { .090/ / - (1) (1) (المتجم الوسيط }
$$


وأغلب الفقهاء يسوي بين: العرف و العادة(؟).

ومنهم من يرى بأن: العادة أعم من العرف وأوسع (r).

و المسألة مسألة اصطلاح، و [لا مشاحة في الاصطلاح]] (؛).

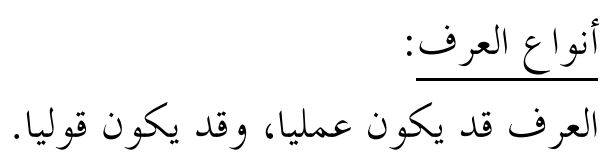

أ- العرف العملي: هو ماجرى عليه العمل، سواءُ أكان ذلك عاما.... مثل دخول

الحمام من غير تعيين زمن، و لا أجرة، أو خحاصا ببلد.... مثل كون رأس المــــال لأهـــل

$$
\text { البو ادي هو الأنعام. }
$$

ب- العرف القولي: فهو ما كان من الألفاظ ووضعها للدلالة على معينٍ معيَّ. وقد أشار بعض الفقهاء إلى تأثير الأعراف على مسألة الكفاءة بصورة عرضية يقول

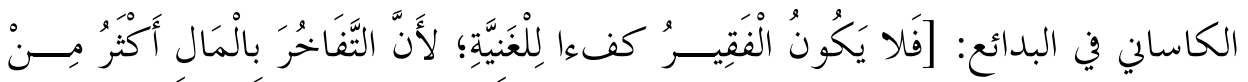

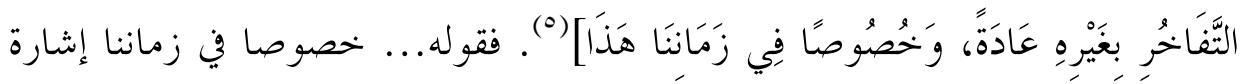
إلى أنه قد قاس هذا الحلكم على عرف زمانه.

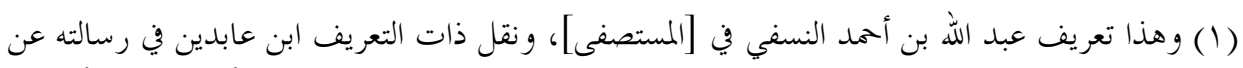

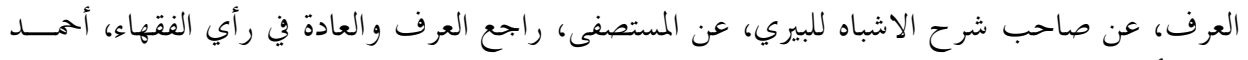

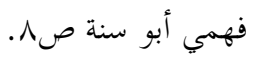

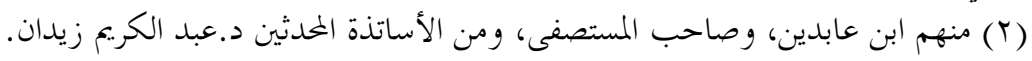

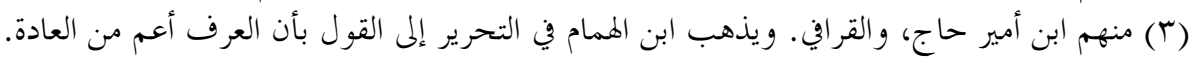

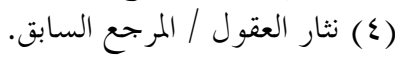


كما أشار إلى رأي الإمام أبي حنيفة - رحمه الله، إلى كون تلك الخصــال عرفيــة

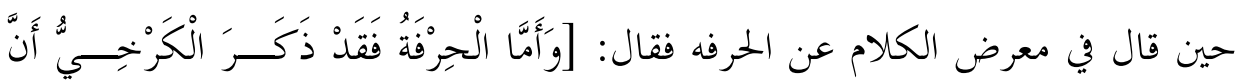

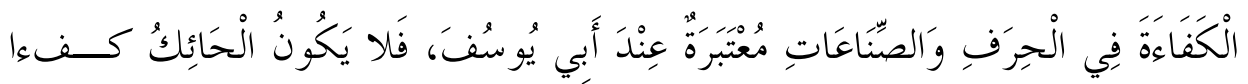

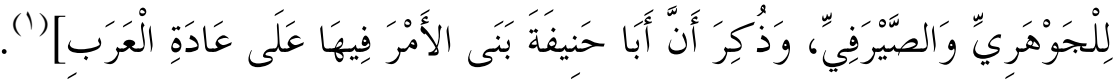

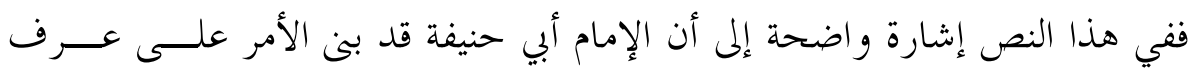
العرب في ذلك الزمان، فإذا تغير الزمان فلامانع من تغير الحكم مادام الحكم قد بــين

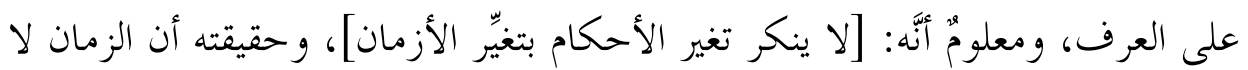
يتغير، وإنما أهل الزمان.... وبالتالي عملهم. ويؤكد هذا الأمر الشيخ محمد أبو زهرة - رحمه الله: إذ يعتبر الكفاءة من الأمـــور الخاضعة للعرف؛ لأن استمرار الحياة الزوجية يستلزم وجود تقارب بين أسرتي الــزوج

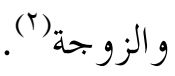

\section{وقد وضع الفقهاء شروطا لأجل اعتبار العرف وللعمل به، من أهمها:}

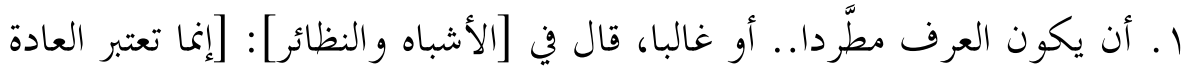

إذا اطردت، أو غلبت، أما الشهرة فلا عبرة هـا] (ب).

$$
\text { r. أن يكون العرف عاما. }
$$

r. أن لايكون العرف خخالفا للشرع. ع. أن يكون العرف الذي يحمل عليه التصرف موجودا وقت إنشاء التصرف، بأن

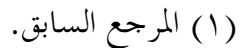

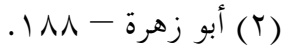

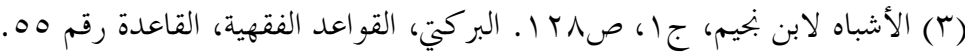$$
-10 \leqslant \text {. }
$$ 
يكون حدوث العرف سابقا على وقت التصرف، ثم يستمر إلى زمانه.. فيقارنه، سواء أكان التصرف قو لا، أم فعلا.

ويقول ابن بنيم في الأشباه: [و العرف الذي تحمل عليه الألفاظ إنما هو المقـــارن(1) السابق، لا المتأخر، ولذا قالو ا: لاعبرة بالعرف الطارئ] (r).

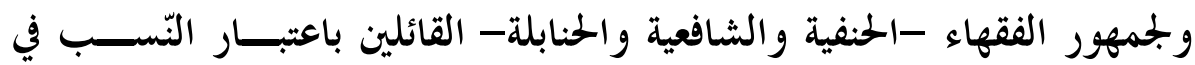

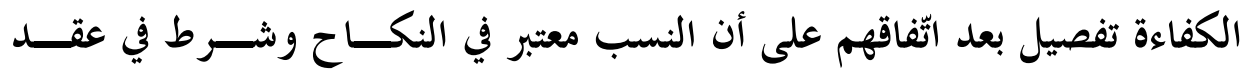

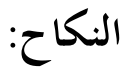
التفصيل في اعتبار النسب عند القائلين به: أولا: عند الحنفية

قريش بعضهم لبعض أكفاء، والعرب بعضهم لبعض أكفاء، و الموالي بعضهم لبعض

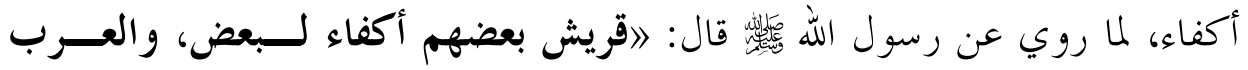

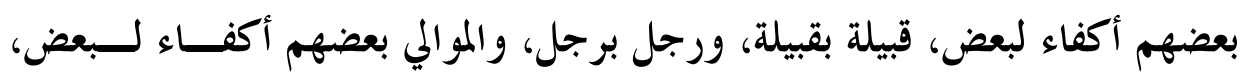

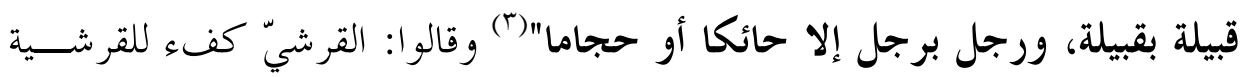

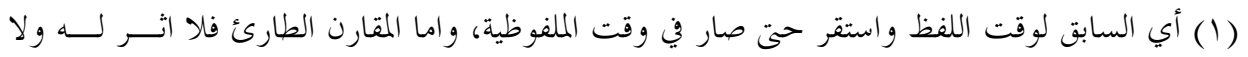

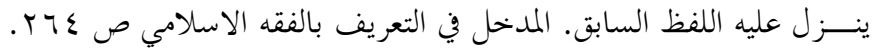

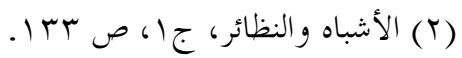

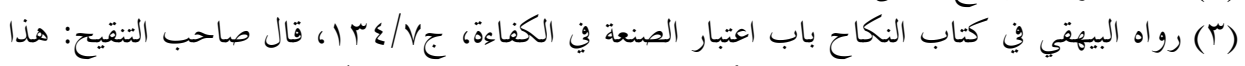

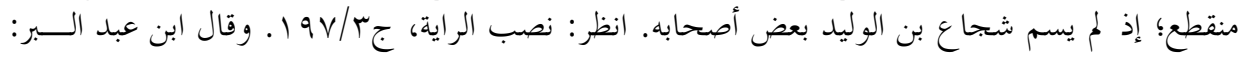

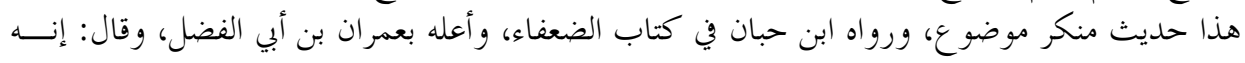

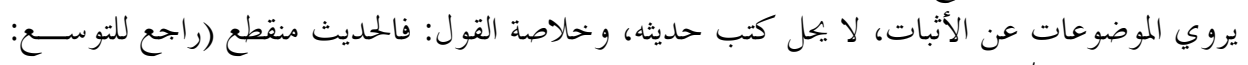


على اختلاف القبيلة، ولا يعتبر التفاضل فيما بين قريش في الكفاءة، فالقرشيّ الــــي

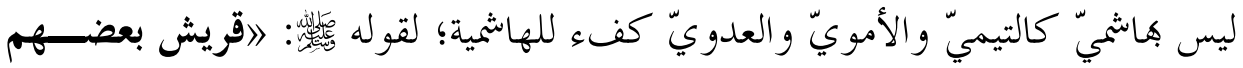
أكفاء لبعض" (1)، وقريش تشتمل على بني هاشم، وإن كان لبني هاشم من الفضيلة ما

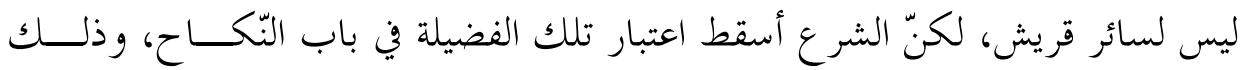

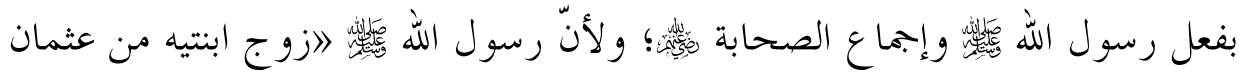

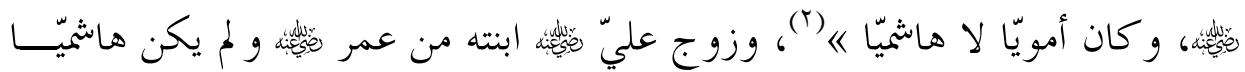

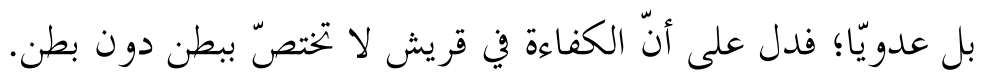

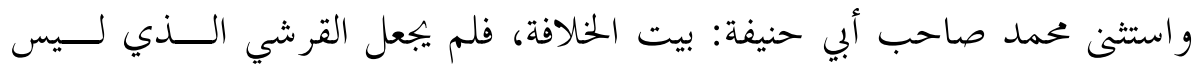
هـاشميّ كفءا له، فلو تزوجت قرشية من أولاد الخلفاء قرشيّا ليس من أولادهم ككــان للأولياء حقّ الاعتر اض. وقال جمهور الحنفية: العرب بعضهم أكفاء لبعض بالنص، ولا تكون العرب كفءا

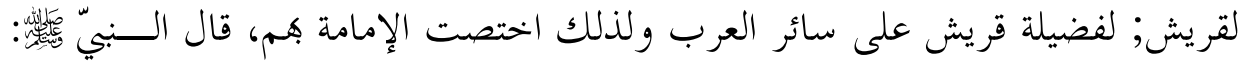
"الأئمة من قريش"("). المو المي بعضهم أكفاء لبعض بالنص، ولا تكون المو الي أكفــاء

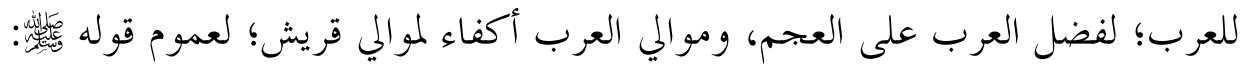
》والموالي بعضهم أكفاء لبعض رجل برجله، ومفاخرة العجم بالإسلام لا بالنّسب، فمن له أبوان في الإسلام فصاعدا فهو من الأكفاء لمن له آباء فيه، ومن أسلم بنفسه أو

(1) فتح الباري 9/ / هب، إسناده ضعيف.

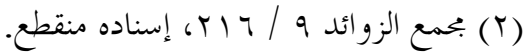

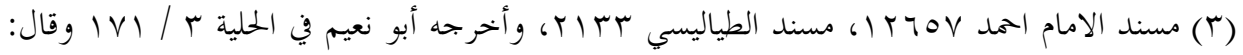
هذا حديث مشهور ثابت من طريق أنس. $-107$. 
له أب واحد في الإسلام لا يكون كفعا لمن له أبوان في الإسلام; لأنّ تمــام النّســـب بالأب و الجدّ، ومن أسلم بنفسه لا يكون كفء المن لم له أب واحد في الإسلام (1).

\section{ثانيا: عند الشافعية}

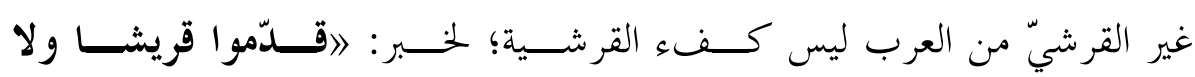

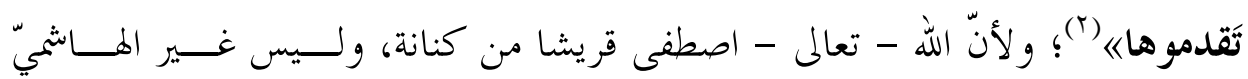

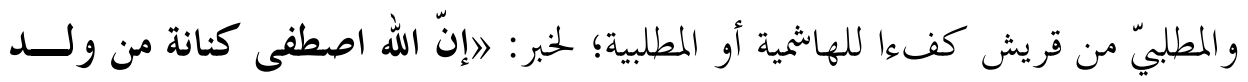
إسماعيل، واصطفى قريشا من كنانة، واصطفى من قريش بني هاشم، واصطفاني من فرين

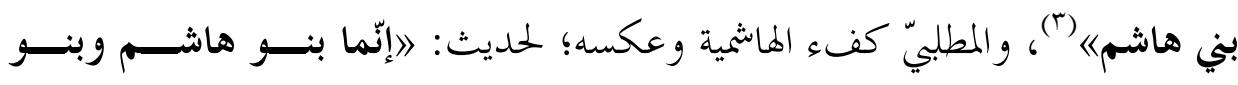

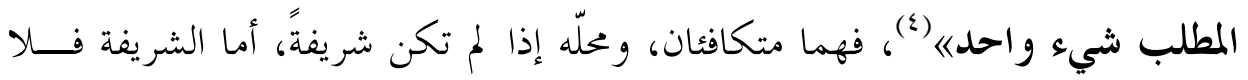
يكافئها إلا شريف، و الشرف مختصّ بأولاد الحسن والحسين - رضي الله تعالى عنهما

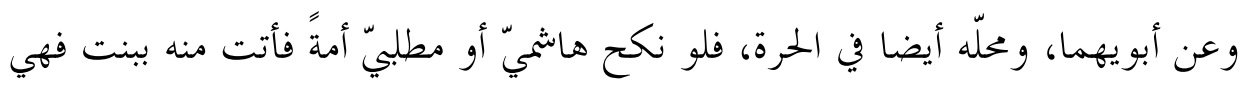

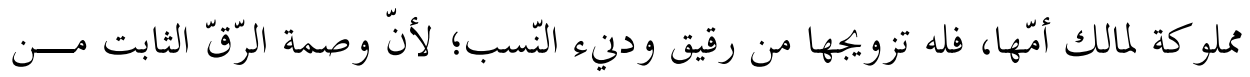

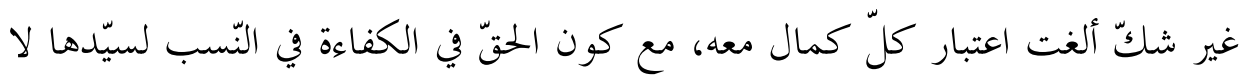
لها على ما جزم به الشيخان، أما غير قريش من العرب فإِّ بعضهم أكفاء بعض نقلـــهـ

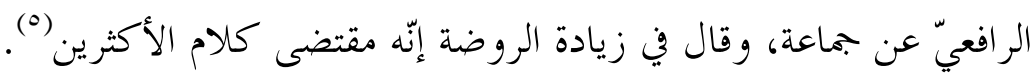

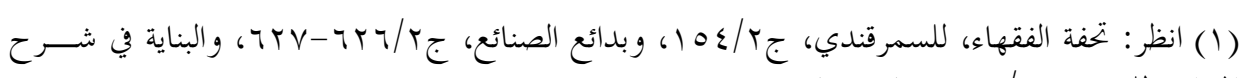

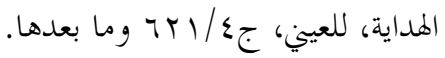

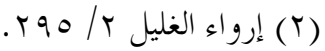

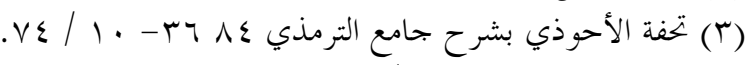

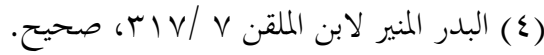

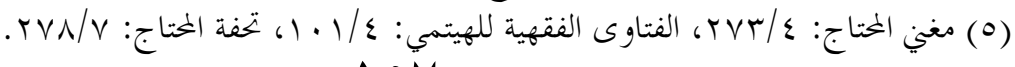


قالوا: الأصحّ اعتبار النّسب في العجم كالعرب قياسا عليهم، فالفرس أفضل مــن

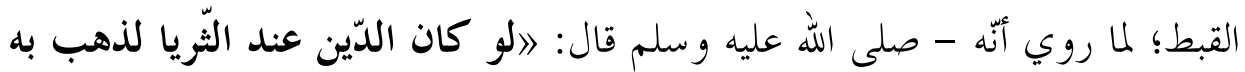
رجل من فارس" (1) و وبنو إسر ائيل أفضل من القبط، ومقابل الأصحّ: أنسّهـه لا يعتــبر

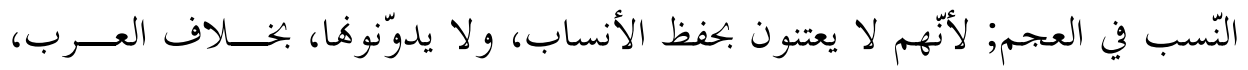
و الاعتبار في النّسب بالأب، و لا يكافئ من أسلم أو أسلم أحد أجداده الأقر بين أقـــدم منه في الإسلام، فمن أسلم بنفسه ليس كفء من لها أب أو أكثر في الإسلام، ومن له له أبو ان في الإسلام ليس كفء من لها ثلاثة آباء فيه (r).

$$
\text { ثالثا: عند الحنابلة الختلفت الرّواية عن أحمد: }
$$

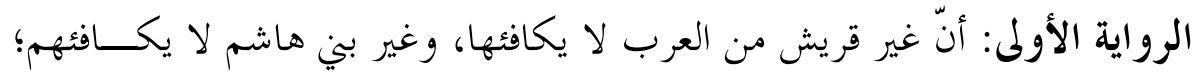

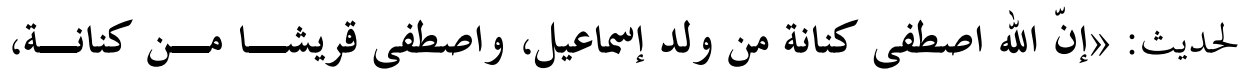
واصطفى من قريش بني هاشم، و اصطفالي من بني هاشمه، ولأنّ العرب فضّلت على

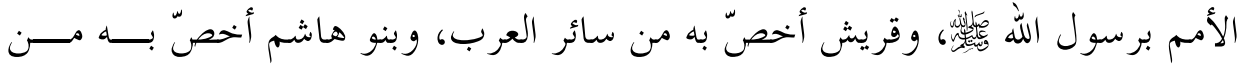

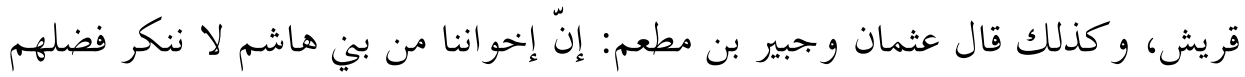
علينا لمكانك الذي وضعك ولك الله به منهم (r). الرّواية الثانية: أنّ العرب بعضهم لبعض أكفاء، و العجم بعضهم لبعض أكفاء؛ لأنّ 
》النّي

المطلب الثاني: نوع اشتراط الكفاءة في عقد النكاح من حيث كونه شرط صحة

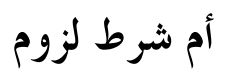

\section{الفرع الأول: تعريف الشرط لغة واصطلاحا}

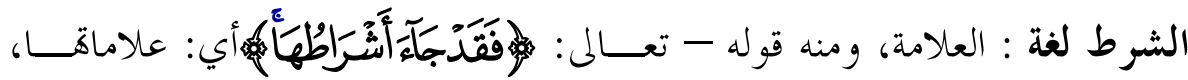
الشرط يقوم على ثلاثة أحرف: وهي الشين، و الراء، والطاء، وهي تدل علــى علـــم

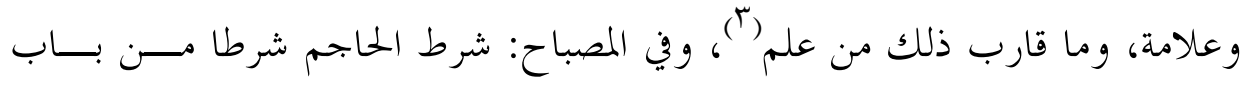
ضرب، وقتل، الواحدة شرطة، وجمع الشرط شروط، مثل: فلس وفلوس، و الشــرط

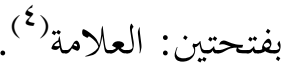
أما في الاصطلاح: فهو وصف ظاهر منضبط، مكمل لمشروطه، يستلزم عدمه عدم

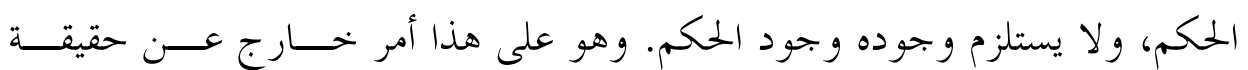
المشرو ط ليس جزءا منه (0). وشروط عقد الزوج عدّدها جمهور الفقهاء بثلاث شروط هي: - 1

$$
\begin{aligned}
& \text { ( ) (1) (1) تقدم تخريجه. }
\end{aligned}
$$

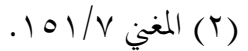

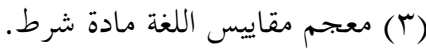

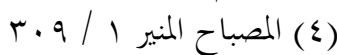

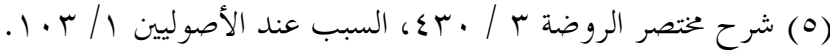

$$
\begin{aligned}
& \text { - } 109 .
\end{aligned}
$$




$$
\begin{aligned}
& \text { r - شروط النفاذ } \\
& \text { r - شروط اللزوم } \\
& \text { و أضاف الحنفية شروط الانعقاد. } \\
& \text { وقد رتبوا على تخلفها آثار وأحكام كما سيأتي. } \\
& \text { الفرع الثاني: أنواع الثروط في عقد النكاح }
\end{aligned}
$$

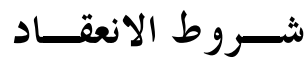

وهي الشروط التى يلزم تو افرها في أركان عقد الزواج أثناء الانعقـــاد والإنشــــاء،

وذلك بسبب إرتباطها كليا بالأركان التي يقوم عليها العقد (').

وهذه الشروط إما أن تتعلق بالعاقدين، أو باللفظ المستعمل، أو بالصيغة.

$$
\begin{aligned}
& \text { أ - الثـــروط المتعلقـــة بالعــاقديــن } \\
& \text { ويشترط في عاقدي الزواج مايلي: }
\end{aligned}
$$

1 - يجب أن يكون كل من العاقدين ذا أهلية، سواء بالبلوغ أو ببلو غ سن التمييز.

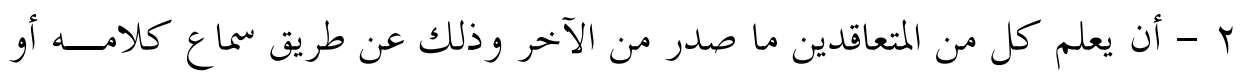
رؤية إشارته أو يقرأ ما كتبه له ويفهم المراد منها. ب - إسلام الزوج إذا كانت الزوجة مسلمة.

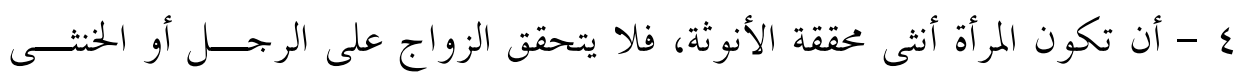
المشكل.

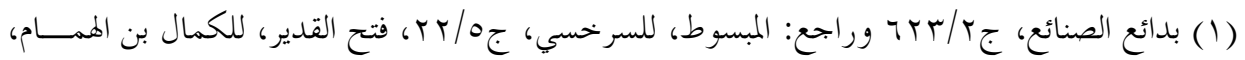

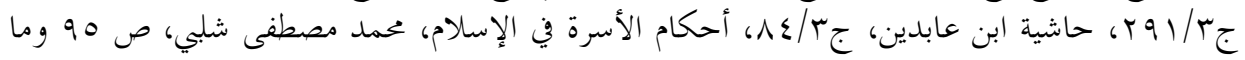

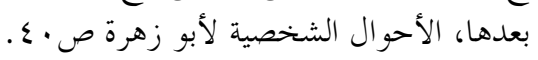


ه - أن تكون المرأة مسلمة أو كتابية، إذا كان الزوج مسلما.

ب - الشروط المتعلقة بصيغة العقد:

1 - أن يكون بحلس العقد متحدا من حيث الزمان و والمكان.

$$
\text { r - أن يكون كل من الإيجاب و القبول متو افقين. }
$$

r - أن يكون القبول فوريا لإيجاب، وهو شرط لم تألحابحد به الحنفية والحنابلة.

$$
\text { ع - بقاء الموجب على إيجابه. }
$$

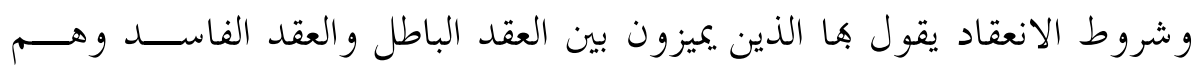

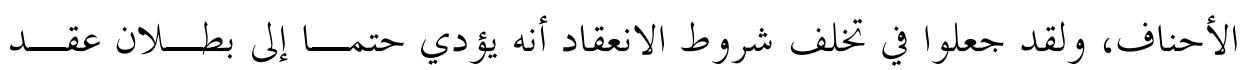

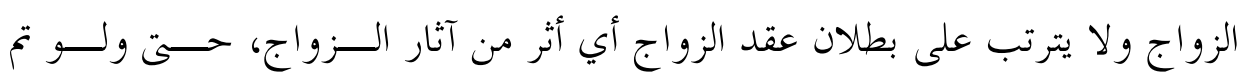
الدخول، وهو في مرتبة العدم ويثبت به النست

\section{شــروط الصحـــة:}

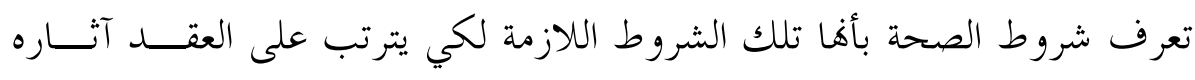

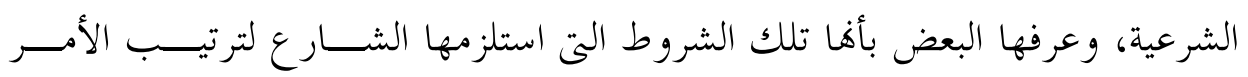

الشرعي على ذلك العقد، وبدوفا لا يعتبر العقد موجودا وجودا يمترمه الشارع (1). وشروط الصحة اتفق الفقهاء على بعضها والبعض الآخر غير متفق عليها:

أ - الشـــروط المتفـــق عليهــــا:

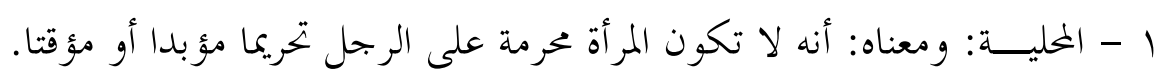

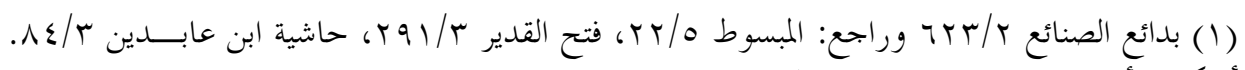

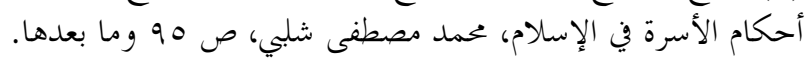


r - شـــرط الصيغة المؤبدة: وهي أن لا يكون الزواج مؤقتا أو زواج متعة. r - أن لا يكون أحد الزوجين مريضا مرضا مخوفا، ويقصد بالمرض المخوف ما يتوقع منه الموت.

$$
\text { ب - الشروط غير المتفق عليها: }
$$

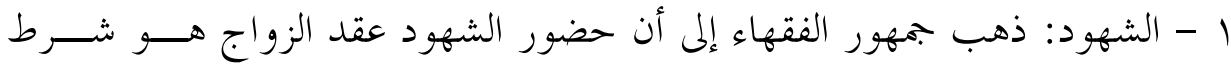

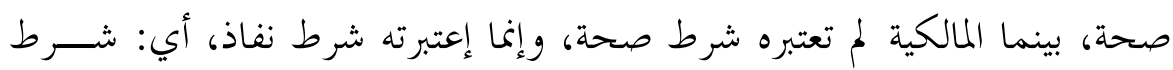
عند الدخول، وجعلت إعلان الزواج شرط صحة، وييهـبـ ألا يتفــق الــزوج و الشهود على كتمان الزواج عن الناس و الجماعة.

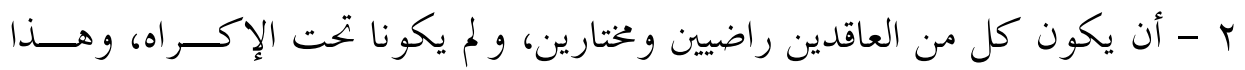
شرط عند الجمهور غير الحنفية.

ولقد رتب جمهور الفقهاء على تخلف شرط من شروط الصحة فساد عقد الزواج؛ وبالتالي لا يحل الدخول بالمرأة، وإذا تم الدخول يجب التفرقة بينهما، سواء اختيــارا أو

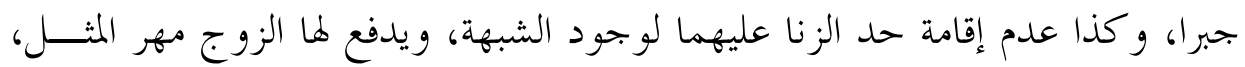

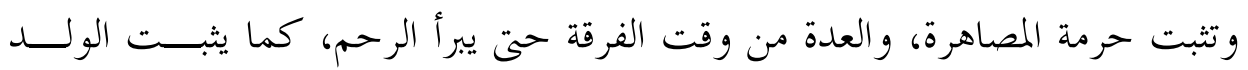
الناتج عن الزواج الفاسد لأبيه.

أما الحنفية فيرون بأنه إذا تخلف شرط من شروط الصحة فإن العقد يكون فاسدا إلا

إذا كانت المحلية أصلية فالعقد يكون هنا باطلال' (1).

(1) المراجع السابقة. 


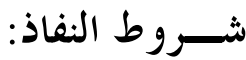

إذا تو افرت في العقد شروط الانعقاد وشروط الصحة انعقد العقد صحيحا، لكــن لكي يكون نافذا أو ليرتب آثناره يجب أن تتوافر فيه شروط النفاد، وتعــرف شــروط النفاذ بأها: تلك الشروط الت لا تنفذ أحكام العقد على عاقديه بغير و جودها(1).

$$
\text { و شـــرورو النفـــاذ هي: }
$$

ا - أن تكون لمتولي إنشاء العقد و لاية إنشائية، فإذا قام ناقص الأهلية بإبرام العقد فلا يكون نافذا، ويكون موقوفا على إجازة وليه مثلا، أو غير الكامل الأهلية الــــي يتولى زواج غيره دون و كالة منه، ففي هذه الحالة العقد يكون موقوفا على إجازه غيره. ب - أن لا يخالف الوكيل مو كله فيما و كله به؛ فإذا خحالف الوكيل الوكالة فإن العقد الذي أبرمه بقي موقوف النفاذ على إجازة المو كل. ب - ألا يكون العاقد وليا أبعد مع وجود الولي الأقرب المقدم عليه، فهنا إذا أبرم الولي

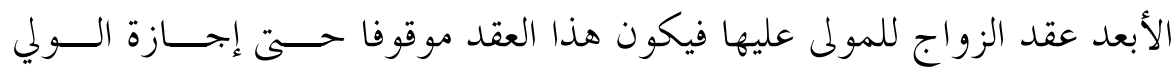

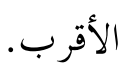

ويذهب جمهور الفقهاء إلى أنه إذا تخلف شرط النفاذ في عقد الزواج كان العقـــد صحيحا إلا أنه لايرتب آثاره إلا إذا أجيز من طرف الذي له حـــق الإجــــازة، و إذا تم الدخول وأجيز رتب العقد آثاره، أما إذا تم الدخول دون إجازة فإنه تترتب عليه نفس

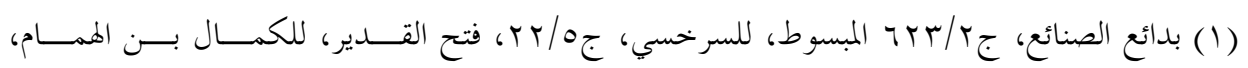

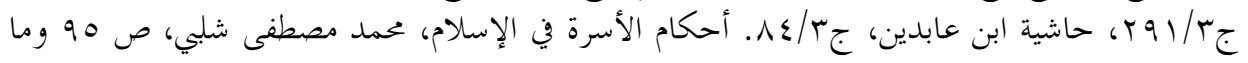
بعدها. 
الآثار عن الزواج الفاسد الذي تخلف أحد شروط الصحة، وهناك اســتثناء بالنســبة للشافعية والحنابلة الذين ذهبوا إلى أن زواج الفضولي لا يستدعي الإجازة؛ لأنه باطل.

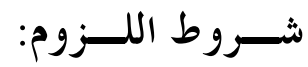

ذهب الفقهاء إلى أن عقد الزواج يكون لازما إذا ما اســتوف شـــروط الإنعقــاد

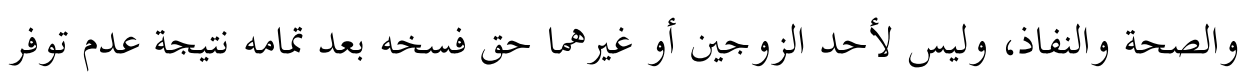

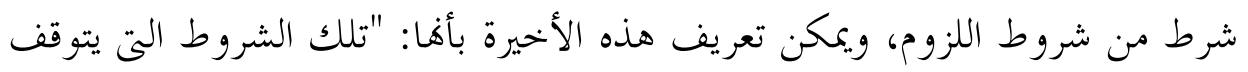
عليها بقاء العقد مستمر ا مرتبا لجميع آثاره". وعرّفت كذلك بأها: "تلك الشروط التى لا يكون لأحد الزوجين أو غيرهما مـــن يتعدى إليه ضرر العقد حق فسخه بعد تمامه" (1).

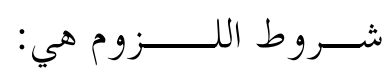

1 - شـــرط خلو الــزوج من العيوب الجنسيـــة والأمراض (r).

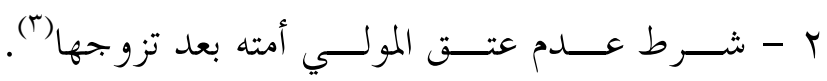

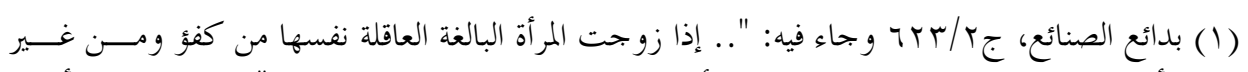

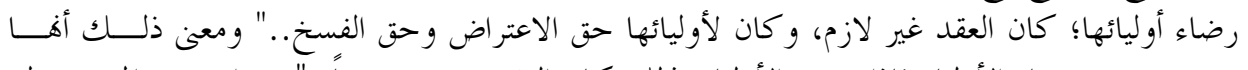

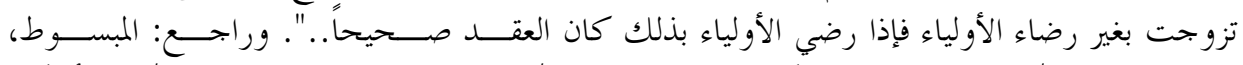

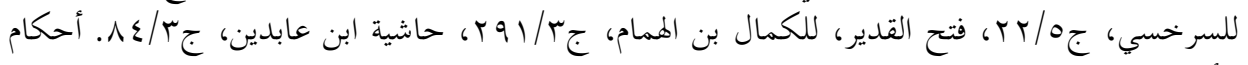

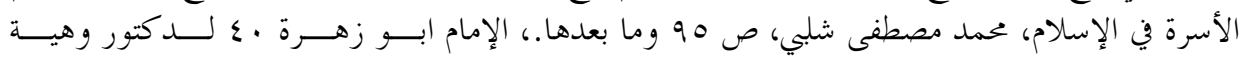

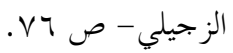

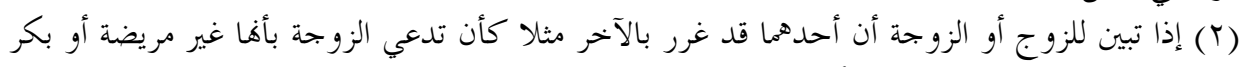

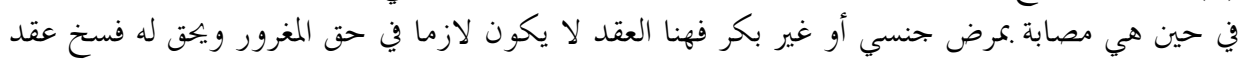
الزواج. (T) وهذا يعني أنه إذا زوّج السيد أمته ثم أعتقها فهنا هذا العقد الذي أبرمه المولى غير لازم في حقها بعدما

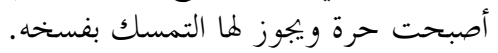


ب - شـــرط الكفــاءة فــي الــــزواج: وهذا موضوع البحث وسنأتي عليـــ

بالتفصيل في الفصل التالي.

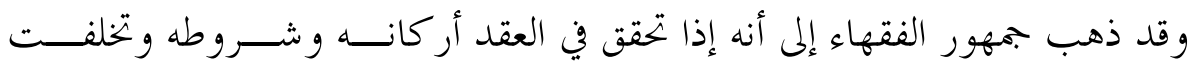
إحدى شروط اللزوم يكون العقد صحيحا نافذا، إلا أنه لا يكون لازما فيجوز لمن له حق التمسك بفسخ عقد الزواج، أي: أن يطلب فسخه، فإذا كان طلب الفسخ قبــل

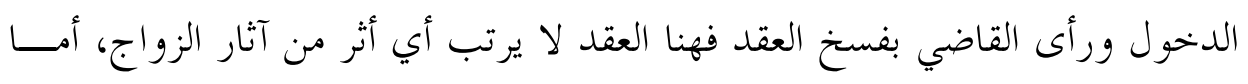

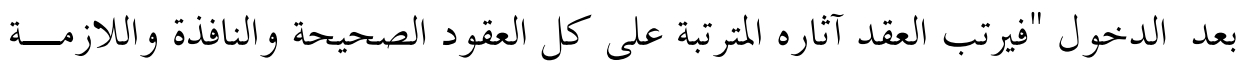

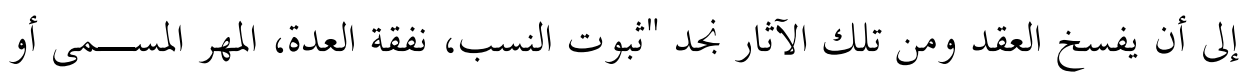

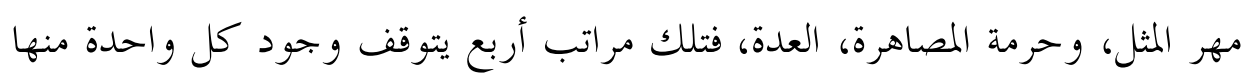
على توافر أمور تسمى في الاصطلاح بالشروط متى وجدت تحققت، وإذا انتفت منها انعدمت.

فشروط الانعقاد هي التي يتوقف عليها سلامة الأمور الأساسية في العقد؛ وهــي:

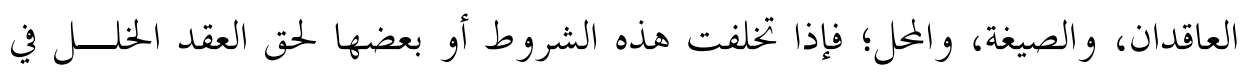
أساسه؛ ويعبر عن هذا الخنل بالبطلان، ويسمى العقد حينئذ باطلا. وشروط صحته هي التي يتوقف عليها صلاحية العقد لترتب الآثار الشرعية عليــ؛

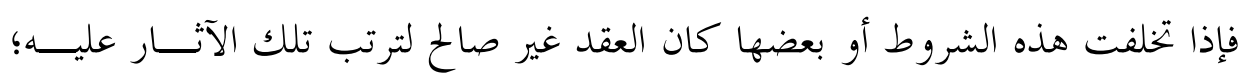
ويعبر عن هذا الخلل بالفساد، ويسمى العقد فاسدا. وشروط النفاذ هي التي يتوقف عليها ترتب الآثار على العقد بالفعل؛ وتخلف هـــــهـ

$$
\text { الشروط يجعل العقد موقوفا. }
$$


وشروط اللزوم هي التي يتوقف عليها بقاء العقد مرتبا عليه آثاره، فلا يكون لأحد

الخيار في فسخه ورفعه من أساسه (1).

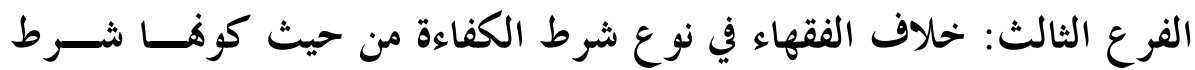

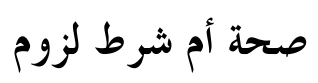

اختلف الفقهاء: هل الكفاءة في النكاح شرط صحة أو شرط لزوم؟ على قولين: القول الأول: إنّ الكفاءة ليست شرطا في صحة النكاح، وإنما هي شرط للــزورم فقط، فيصحّ النّكاح مع فقدها، ولا يبطل العقد ولا يفسد إذا لم توجد الكفاءة، بــل يعطى الحق لمن له المصلحة في وجوده، وله الخيار في طلب الفسخ أو إمضائه.

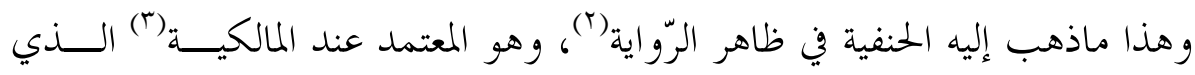

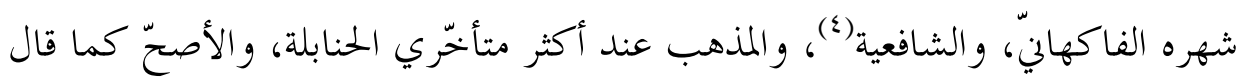

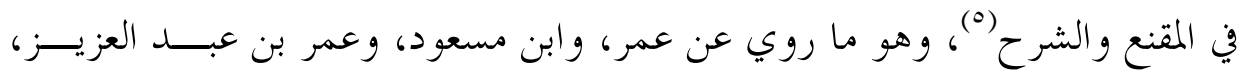

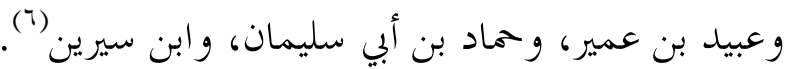

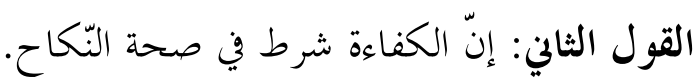

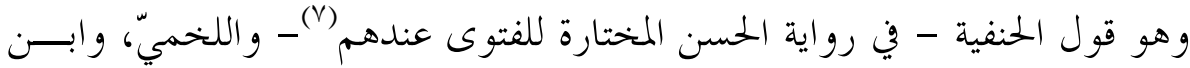

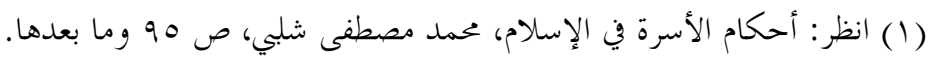

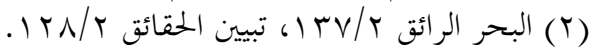

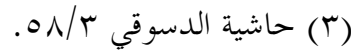

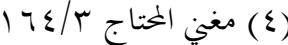

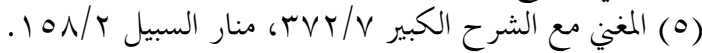

$$
\begin{aligned}
& \text { (7) المر اجع السابقة. }
\end{aligned}
$$

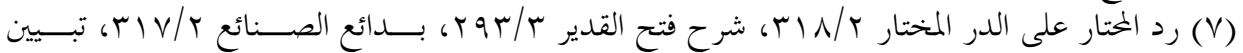

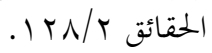


بشير، و ابن فرحون وابن سلمون - من المالكية(')- وهو رواية عن الإمام أحمد(؟).

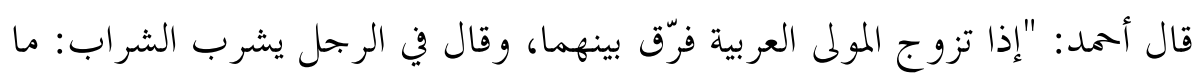
هو بكفء لها، يفرق بينهما، وقال: لو كان المتزوّج حائكا فرقت بينهما..."("ال).

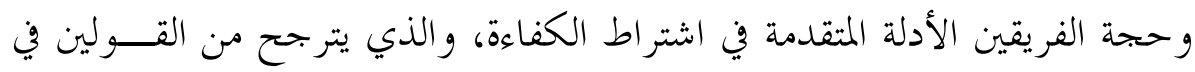
هذا البحث أن شرط الكفاءة في عقد النكاح شرط لزوم لا شرط صحة، فإذا تزوجت

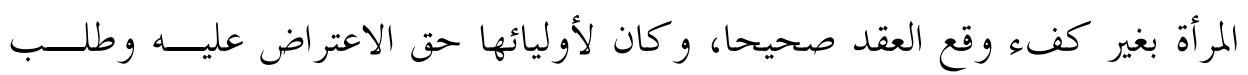

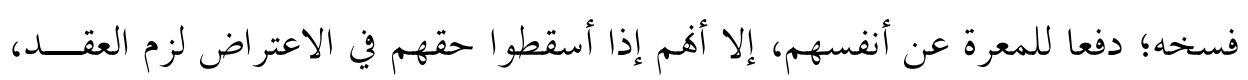
فلو كانت الكفاءة شرطا لصحة العقد لما صح العقد أصلا، حتى لو أســقط الأوليــاء حقهم في الاعتر اض.

\section{المطلب الثالث: حكم فسخ النكاح لعدم الكفاءة} الفرع الأول: تعريف الفسخ لغة واصطلاحا يأتي الفسخ في اللغة على عدة معان منها:

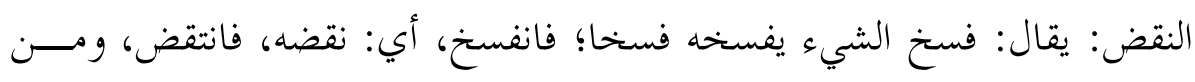
الجحاز: انفسخ العزم و البيع و النكاح: انتقض. الإزالة: تقول: فسخت العود فسخا: أزلته عن موضعه فانفسخ، وفسخت المفصل

$$
\begin{aligned}
& \text { عن موضعه، أي: أزلته. } \\
& \text { الإلقاء: يقال: فسخت الثوب: ألقيته. }
\end{aligned}
$$

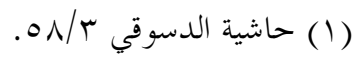

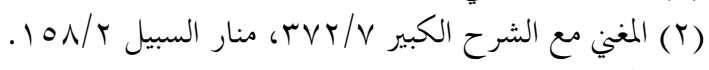

$$
\begin{aligned}
& -17 V \\
& \text { (r) المراجع السابقة. }
\end{aligned}
$$


الرفع: فسخت العقد فسخا: رفعته، و تفاسخ القوم العقد: توافقو اعلى فسخه (1). جاء في تاج العروس: الفسخ: الضعف في العقل والبدن، و الجهل، و الطرح، وإفساد

تعريف الفسخ اصطلاححا: هو حل ارتباط العقد (r). أو : هو ارتفاع حكم العقد من الأصل كأن لم يكن (ع) فتستعمل كلمــــة الفســخ أحيانا .معنى رفع العقد.

وعرفه سمارة: "بأنه نقض عقد الزواج بسبب خلل وقع عند العقد، أو بسبب خلل أصاب العقد بعد انعقاده، ولكنه خلل يمنع من بقاء العقد واستمراره"(•). الفرع الثاني: حكم فسخ عقد النكاح لعدم تكافؤ النسب

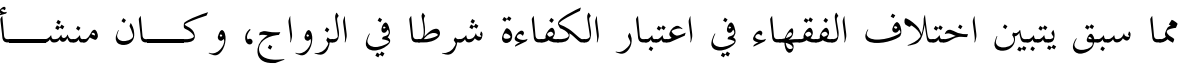
خلافهم في اعتبارها شرطا من شروط العقد أو لا، فمن لم يعتبرها شرطا من شــروط العقد لم يقل .مشرووعيتها، وعليه ينعقد العقد ويعتبر صحيحا و نافذا و لازمـــا، وومــنـ

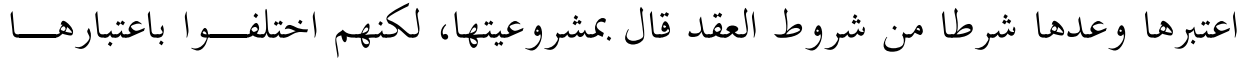
شرطا من شروط اللزوم، وينبين على هذا الخلاف أننا لو قلنا بأها شرط من شــروط الصحة وزوجت المرأة نفسها من غير كفء أو زوجها وليها بغير الكفء كان العقـــ

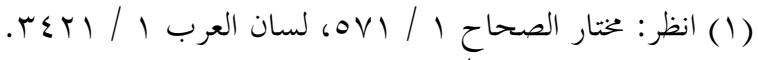

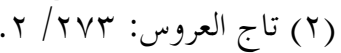

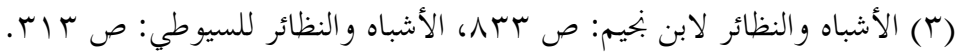

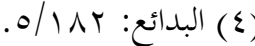

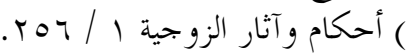


فاسدا على قول الحنفية(')، و كان باطلا عند الإمام أحمد (r)، وأحد قولي الشــافعي (r)"،

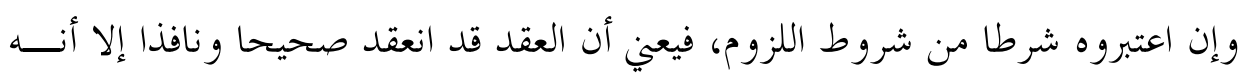

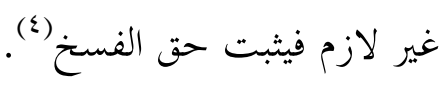

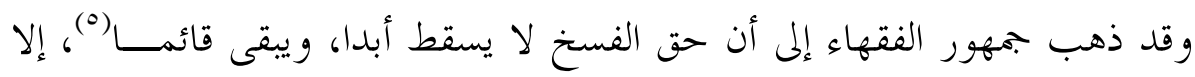
الحنفية هم الذين قالوا بسقوط الكفاءة بالولادة، فلا يحق لأحدهم طلب الفسخ لعـــدم الكفاءة بعد الوالدة؛ وذلك رعاية لمصلحة الطفل حتى يتربى في كنف و الديــه، فــإن بقاءهم بحتمعين على تربيته أحفظ، حتى لا يضيع الولد بالتفريق بين والديه، وينبغــي إلحاق الحمل الظاهر به (1). وقالوا: إذا رضيت المرأة وبعض الأولياء، لم يكن لباقي الأولياء فسخ؛ لأن هذا الحق

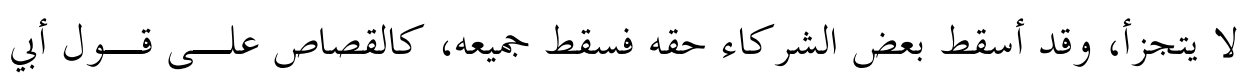
حنيفة (V) قال ابن قدامة: ولنا أن كل و احد من الأولياء يعتبر رضاه، فلم يسقط برضى غيره،

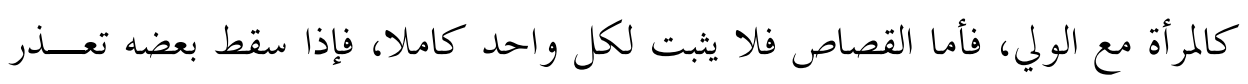

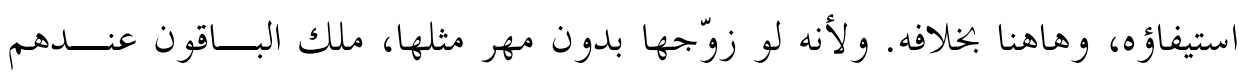

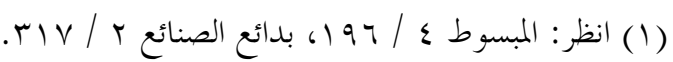

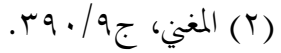

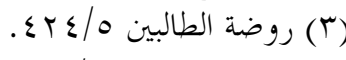

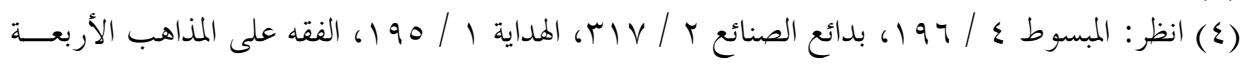


الاعتراض، مع أنه خالص حقه، فهاهنا مع أنه حق لهم أولى، وسواء كانو ا متساوين في الدرجة أو متفاوتين، فزوّج الأقرب، مثل أن يزوج الأب بغير كفء، فــإِن للإخهـوة الفسخ، وظاهر كلام صاحب الزاد أنه حتى أولادها يفسخون؛ لأفم أولياء.وقال مالك و الشافعي: ليس لمم فسخ إذا زوج الأقرب؛ لأنه لا حقّ للأبعد معه، فرضاؤه لا يعتبر.

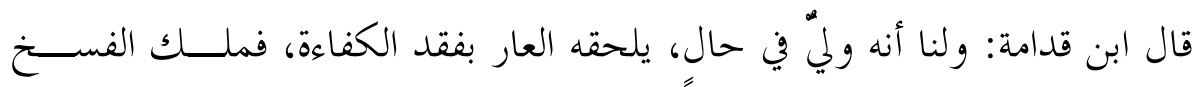

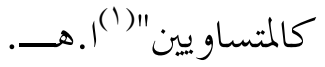
وعلى هذا أن اشتراط الكفاءة في النسب لصحة النكاح غختلف فيه بين المـــذاهب

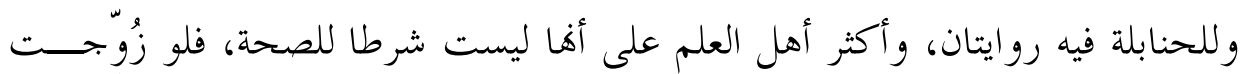

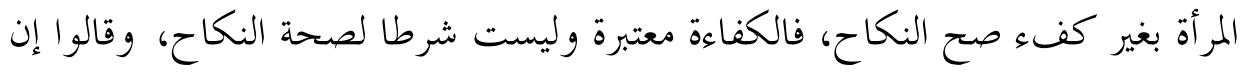

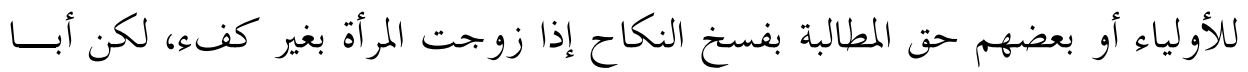
حنيفة يقول: إذا رضيت المرأة وبعض الأولياء فليس لباقي الأولياء حق الفسخ. ومالك والشافعي يقولان: إذا زوّج الولي الأقرب فليس للأبعد حق الفسخ؛ لأن رضا الأبعد لا يعتبر.

و الصحيح أنه ليس لأحد الحق في فستخ النكاح مادام النكاح صحيحا، وتم العقـــــ برضا المرأة والولي لا يفسخ، وإذا صح العقد بمقتضى الدليل الشرعي لايمكن فسخه إلا

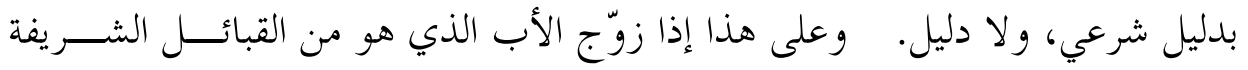
المعروفة بمن ليس بقبيلي فالنكاح صحيح، وليس لأحد من أوليائها أن يفسخ النكاح،

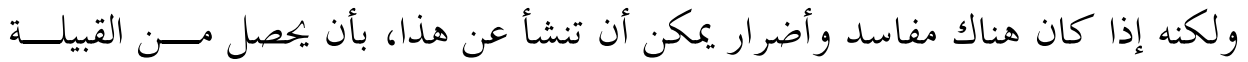




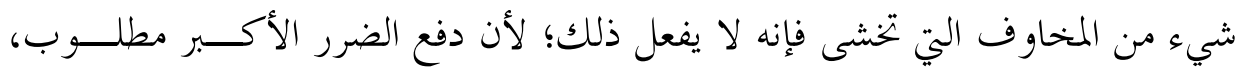

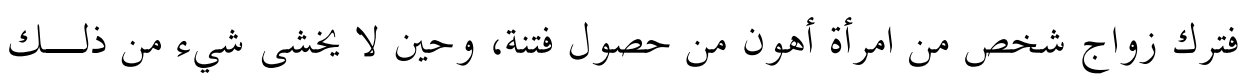

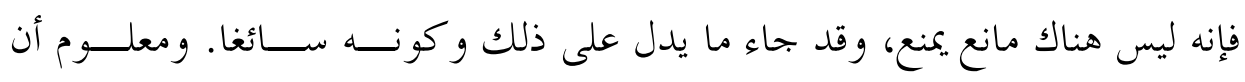

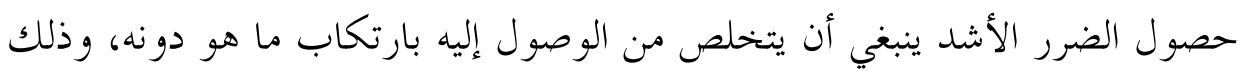
إذا كان سيؤدي إلى ما هو أشد كما هو الحال في النسب. * * 


\section{الفصل الثالث}

\section{موقف نظامر المرافعات من مسألت تكافؤ النسب وجهود وزارة العدل}

إن العدل يمثل القيمة العليا التي قامت عليها السماوات والأرض، وهو الغاية الــتي

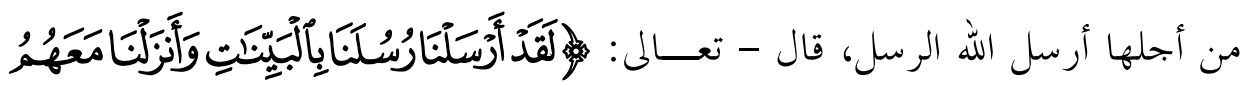

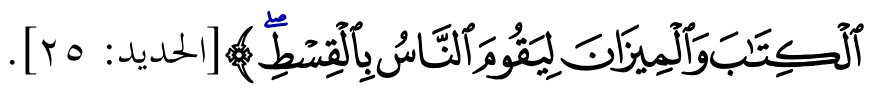

ومفهوم العدل من حيث وضعه اللغوي و الشرعي عام، ولا يقتصر علــى المفهـــوم القضائي، وأنه يوجز في ثلاث كلمات: "وضع الأمور في مو اضعها"، ويسهب البعض بقوله: "إنه إعطاء كل ذي حق حقه بلا إفراط و لا تفريط". ثم إن بعض الكتابات القانونية تتجاوز المفهوم الدقيق للعدل؛ فتدخل المســــاواة في مفهوم العدل، وأن هذا غير دقيق، فالمساواة في بعض الوقائع تخرج عن حيز العدل إلى الجور، ولذلك احتاج لفظ المساواة إلى قيد العدل؛ فيقال: "المساواة العادلة"، كالميراث فللذكر مثلُ حظّ الانثيين، فهنا لم تحصل مساواة بين الأولاد (الذكور والإناث)، لكنها قسمة عادلة؛ مراعى في ذلك حكمٌ إسلامية عالية. ومسيرة العدل بالمملكة العربية السعودية تنقسم الى قسمين:

الأول: عدل في الأحكام، وهذا ثابت لا يتغير، ولا يقبل المساس به؛ لأنــهـ يمثــل ثوابت الدولة في تطبيق أحكام الشريعة الإسلامية، يضاف لذلك عدالة تطبيق النظــام

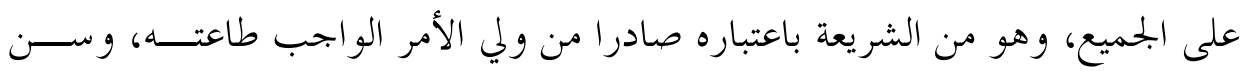

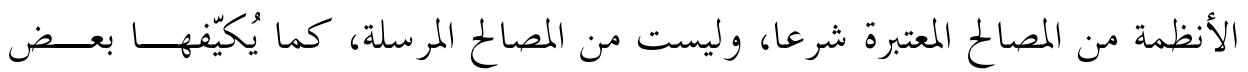




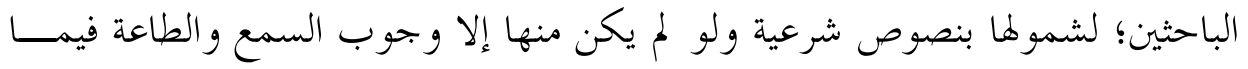
أمر به ولي الأمر، ولأن فيها حفظا للضروريات الخمس. الثاني: مسيرة عدلية في الإجراءات القضائية و التوثيقية والهيكلة الإدارية، وهذه هي

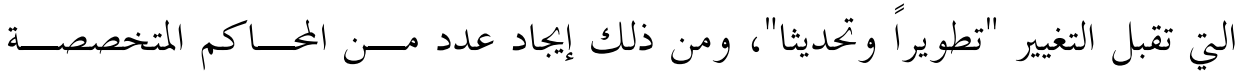

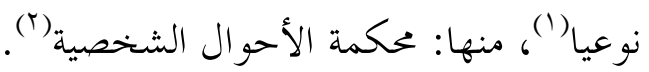
واختصاص محاكم الأحوال الشخصية حسب مشروع نظام المرافعــات الشـــرعية الجمديد الذي تمت أحالثه إلى بحلس الشورى مؤخرا ما يلي: حددت المادة سب منه: تختص محاكم الأحوال الشخصية بالنظر في الآتي:

\section{أ - جميع مسائل الأحوال الشخصية، ومنها:}

ا - إثبات الزواج، و الطلاق، و المخلع، وفسخ النكاح، و الرجعة، و الحضانة، والنفقــة، و الزيارة. ץ- إثبات الوقف، و الوصية، و النسب، والغيبة، والوفاة، وحصر الورثة.

(1) وزير العدل السابق محمد العيسى الأمر الملكي الكريم يقضي بعدم نظر المحاكم في القضايا ذات الطابع الإعلامي والثقاف أياً كان مصدرها.

http://www.alriyadh.com/522193

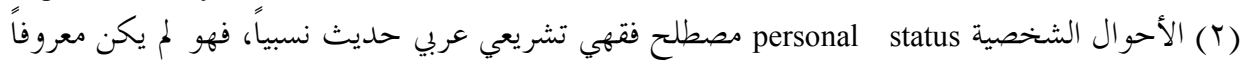

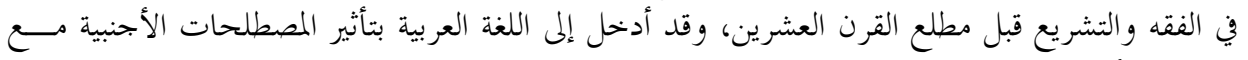

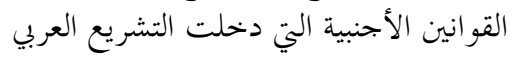

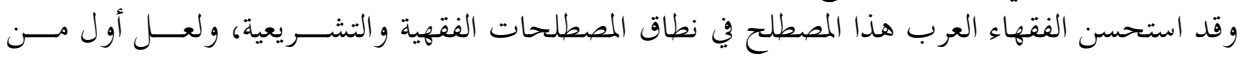

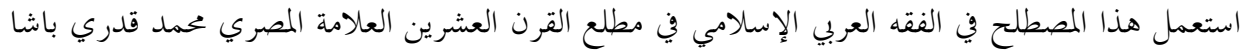

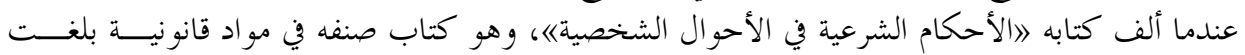

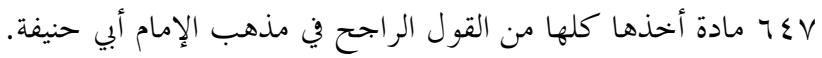


بـ- الإرث، وقسمة التر كة بما فيها العقار إذا كان فيها نــزاع، أو حصــة وقــــ أو وصية، أو قاصر، أو غائب.

ع - إثبات تعيين الأوصياء، وإقامة الأولياء والنظار، والإذن لهم في التصـــفات الــتي

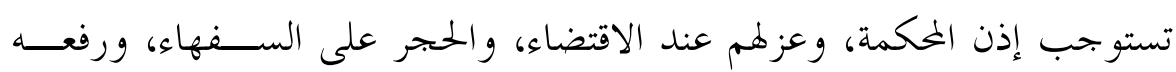
عنهم، وتحدد لوائح هذا النظام الإجراءات اللازمة لذلك. 0- إثبات تو كيل الأخرس الذي لا يعرف القراءة و الكتابة. 7- تزويج من لا ولي لها، أو من عضلها أولياؤها. ب- الدعاوى الناشئة عن مسائل الأحوال الشخصية. جـ - الدعاوى المرفوعة لإيقاع العقوبات المنصوص عليها في نظام الميئة العامة للو لاية على أموال القاصرين ومن في حكمهم. وموضوع التفريق لعدم الكفاءة في عقد النكاح من المواضيع المندرجة ضمن قضايا محكمة الأحوال الشخصية، إلا أن نظام المرافعات الشرعية لم تتطرق نصوصه إليه، و لم تفرد له نصا وافيا واضحا على كون الكفاءة شرطا لصحة عقد النكاح أو نفـــاذه أو لزومه، ومن يفسخ العقد، ومتي يمق للأولياء أو المرأة الفسخ وعدمده. وعلى رغم من إحالة المادة الأولى من نظام المرافعات إلى مبادئ الشريعة الإسلامية والتي جاء فيها: "تطبق المحاكم على القضايا المعروضة أمامها أحكام الشريعة الإسلامية،

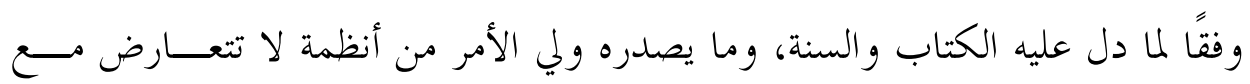

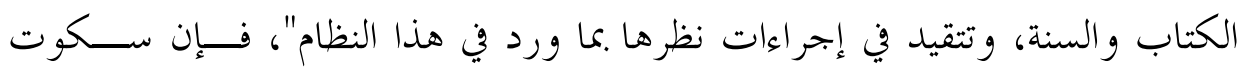
المشرع عن تنظيم موضوع الكفاءة في عقد النكاح يعد مدخلا لكثير من الخلافات التي 
تقع و التي يجب معالجتها؛ وذلك لكثرة المسائل الخلافية المتعلقة بموضـــوع ع الكفـــاءة في الفقه الإسلامي، فضلا عن أهميته في ربط الحياة الزوجية و الأسرية واستقرارها. ومعلوم أن قضايا تكافؤ النسب تتصل بالطابع القبلي لا الاجتماعي وهو الأمر المخالف لحماية

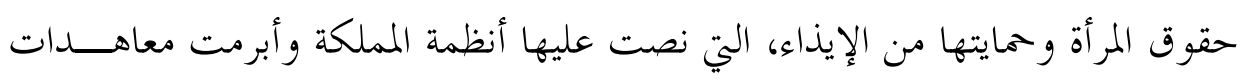

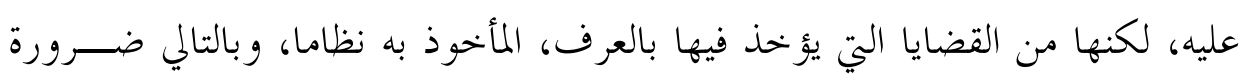

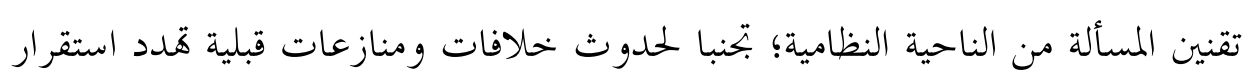

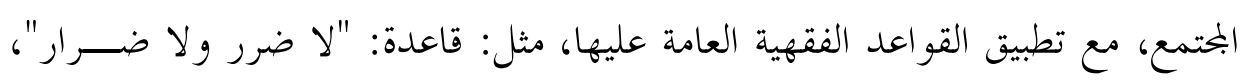

$$
\text { وقاعدة: "الضرر يزال"، وقاعدة: "الساقط لا يعود". }
$$

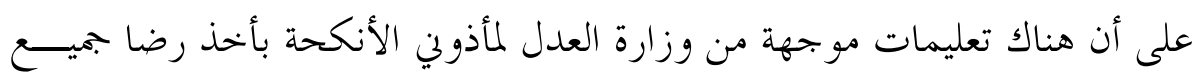
الأطراف، والتأكد منهم بعدم حصول ضرر؛ حتى يكون هناك توفيق بــين الــزورجين

$$
\text { بدون ضرر على أحد. }
$$

ولكن بحرد إصدار تعاميم فيما يخص هذا الموضوع لايكفي لضبط المسألة، وإنمسـا

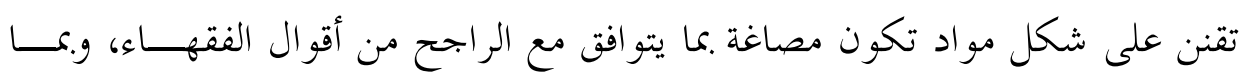

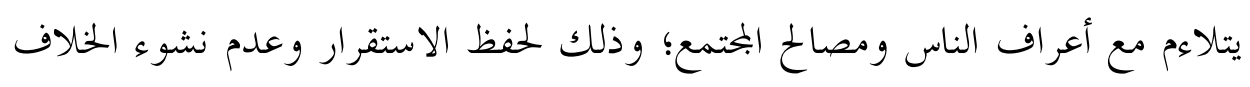
و المنازعة.

ولذلك أوجه دعوة للمشرع إلى تنظيم نصوص نظاميــة ضــمن مـــــاد نظـــام المر افعات الشرعية، ومن الممكن أن تؤخذ هذه النصوص بعين الاعتبار: تختص محاكم الأحوال الشخصية بالنظر في الآتي: أ - جميع مسائل الأحوال الشخصية، ومنها: الكفاءة في النكاح، وتتضمن مايلي: 


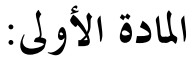

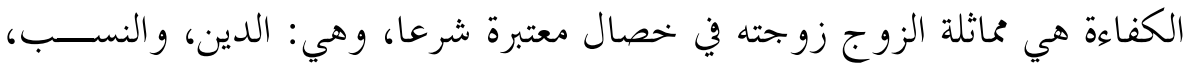

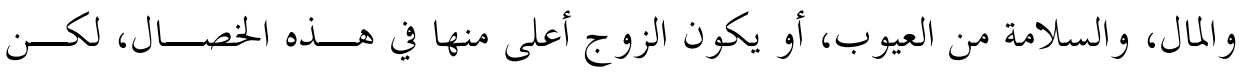
بانعدامها تعيّر المرأة وأولياؤها به.

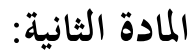

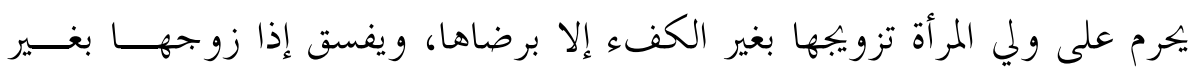
الكفء ودون رضاها.

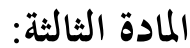

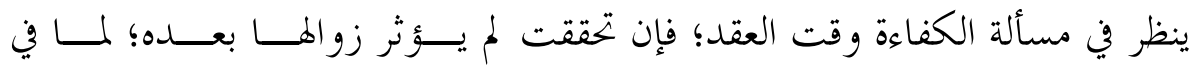
استمر ايتها بعد الدخول والولادة من الحرج، والحرج مدفوع شرعا.

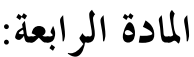

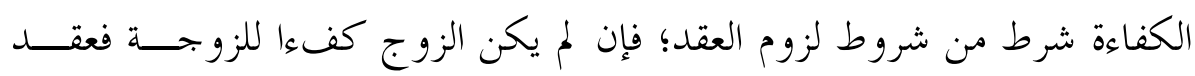
النكاح صحيح، لكن يجوز لكل من المرأة والولي طلب الفسخ.

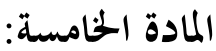

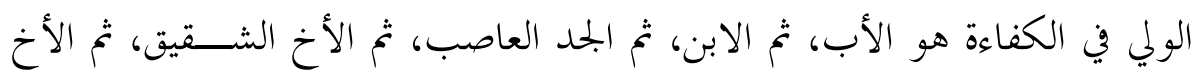
لأب، ثم العم الشقق، ثم العم لأب فقط.

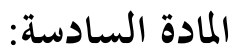

يسقط حق الولي الأبعد في فسخ العقد بموافقة الولي الأقرب والمـــرأة إذا انعـــمت الكفاءة. 


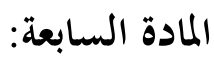

لكل من المرأة ووليها الحق في طلب فستخ العقد عند فو اتما، وإذا أسقط أحســهما لم

$$
\text { يؤثر ذلك في حق الآخر. }
$$

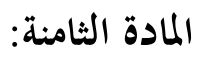

يسقط الحق في الكفاءة برضا المرأة ووليها، ومن رضي فقط أسقط حقه، والساقط

لايعود.

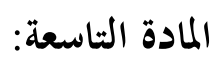

يسقط الحق في الكفاءة بالولادة واستمرار الحياة الزوجية، ويرجع تقدير هذه المــــة إلى السلطة التقديرية للقاضي.

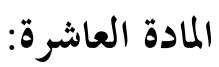

إذا ادعى الزوج الكفاءة ثم تبين أها لم تكن قائمة وقت العقد جاز لكل من المـــــأة ووليها حق طلب الفسن؛ للتغرير الذي صاحب العقد؛ فأفقده حقيقة الرضا. المادة الحادية عشر:

تشترط الكفاءة في جانب الزوج لمصلحة الزوجة، ولا تشترط في جانب الزوجة إلا

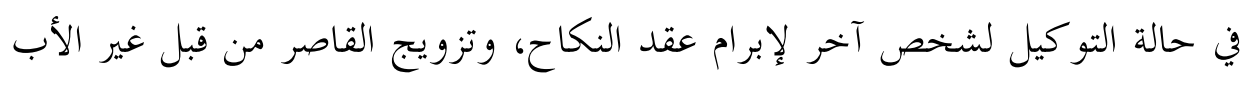
و الجد.

آراء القضاة و القانونيين في مسألة تكافؤ النسب:

إن القضاء السعودي لم يبن على قو اعد عنصرية ليفرق بين زوجين لأجل تكــــافؤ

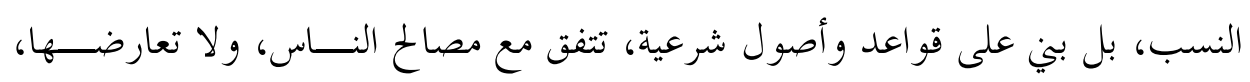


و تغلب فيها المصلحة العامة لأطراف القضية، كما أن الحلكم يدور مع علتــه وجـــودا وعدما؛ ولذذا فلا يمكن نقد حكم دون الإلمام بكسبباته ودواعيه.

وقد أكد قاضي محكمة التمييز الدكتور إبراهيم الحضيري: أنه يجق للشرع فسخ عقد النكاح غير مكتمل الشروط، لافتا النظر إلى أن مسألة كفاءة النسب من المسائل

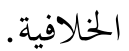

وقد أرجع فقهاء ومستشارون شرعيون نقض محكمة التمييز لأحكام قضت بتفريق

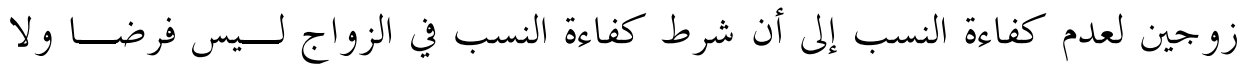
مستحبا، إنما هو من الأعراف و العادات بين الناس من جهة، ولاختلاف الفقهــاء في تحديد الكفاءة المقصودة: هل هي كفاءة الدين أو كفاءة النسب من جهة أخرى (1). يقول الدكتور مسفر القحطاني رئيس قسم الدراسات الإسلامية بجامعة الملـــك فهد للبترول: "المسألة من حيث النظر الشرعي فيها خحلاف، و الجمهور على اعتبــار الكفاءة بالنسب، كما هو مستقر عند العرب من غير نكير في الجاهلية، وفعل البي لئي في تزويجه لغير الأكفاء في النسب دليل على الصحة، ولا ينافي الاشــتراط بالنســبـ كشرطٍٍ لكمال العقد وكونه الأوفق لحال بعض الأزواج في بعض القبائل.

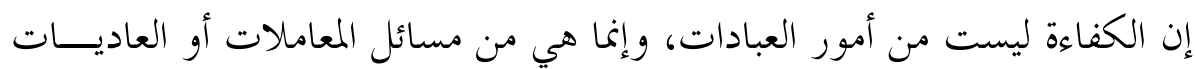
التي يهكم فيها العرف، ويستدل عليها بالقياس؛ لأها تابعة لمصالح الناس ورفع الضـــرر عنهم، ومدارها على التعيير المخل بالحياة الزوجيــة والوفــــاق المســتقبلي للــزوزجين وأو لادهما، فكل رجل كفء لمن تزوج منهم إذا لم يلحقهم عار بتزويجه بين قـومهم؟؛ 
ولذلك قالوا: إن العالم كفء لبنت الشريف و الحسيب، وإن كان نســبه وضــيعًا أو

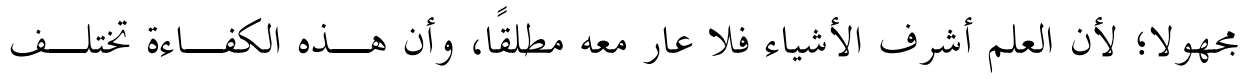

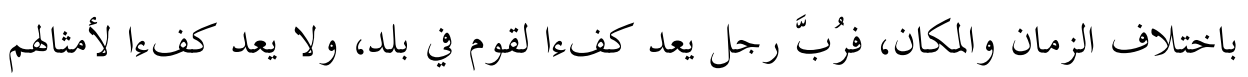
في بلد آخر؛ لاختلاف العرف. فالعرف القبلي إذا لم يكن مصادما للنصوص الشرعية

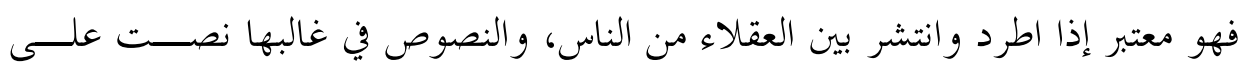

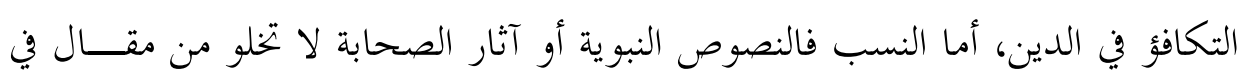

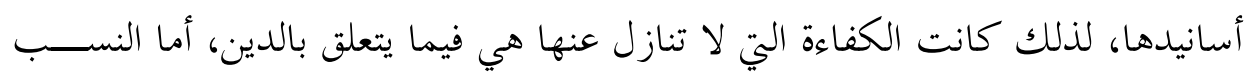

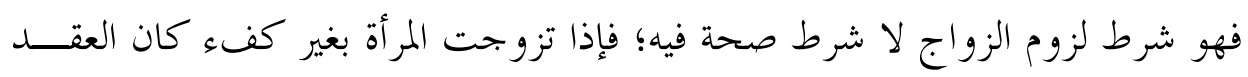

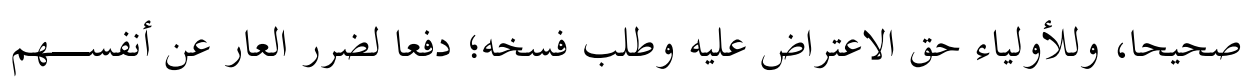

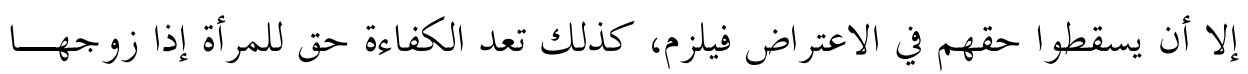

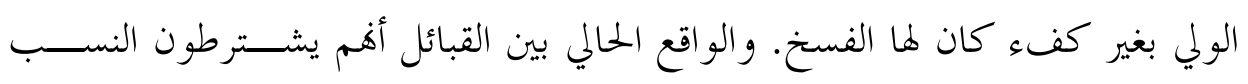

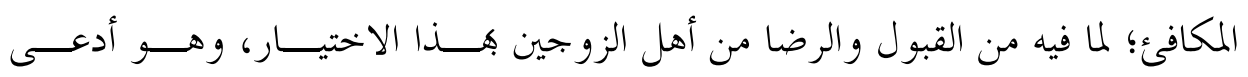

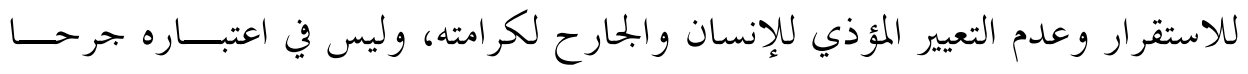
للآخرين، بل هي أعراف مستقرة تساهم في خلق المناخ والاستقرار بين الناس في تلك المحتمعات. ولأسف إن حدوث حالات انفصال بين أزواج غير أكفاء بعدما استقرت

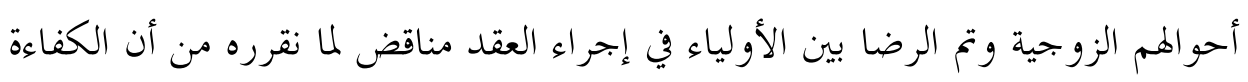

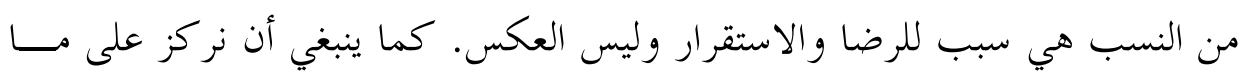
هو أهم وأولى في حياة المقبلين على الزواج وهو كفاءة الأخلاق والصلاح، وينبغـي لئي للأولياء أن يسألو اعن صلاح دينه وخلقه قبل نسبه و وعائلته؛ فهو الأدعى للوئام و المحبة 


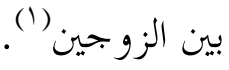

يؤ كد رئيس لجحنة الخامين في المدينة المنورة سلطان بن زاحم: "أن من حق المـــــأة

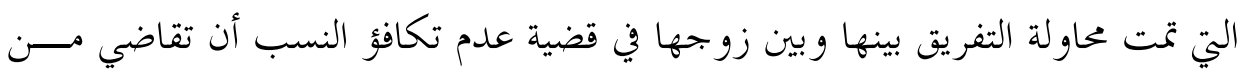

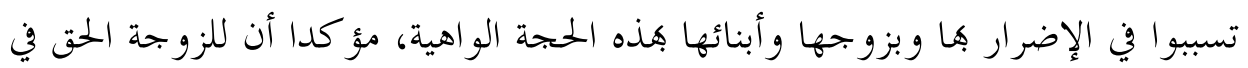

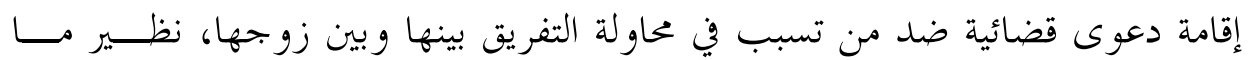

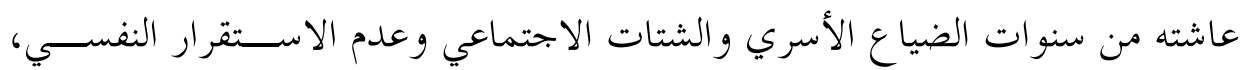
مبينا أن صدور حكم قضائي ضد المتسببين سيكون بمثابة ردع خاص لهم، وردع عام

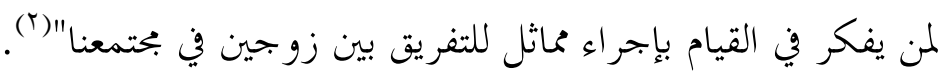
وفي السياق ذاته يرى الخامي خحالد الخحمادي: أن مثل هذه القضايا تؤجج العنصرية

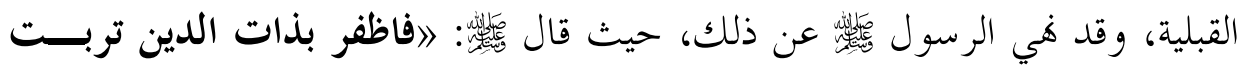
يداك《، و انتقد المحامي خالد الحلواني الطلاق لعدم تكافؤ النسب، مشيرا إلى أن نســبة الطلاق في المملكة مرتفعة وقال: لالم ينظر إليها الإسلام من الناحية الشرعية والقانونية، و اشترطت شروطا أساسية، وهي الدين والأخلاق والكفاءة والقدرة، و لاشك أن هذه الممارسات و المبادئ ما هي إلا معتقدات جاهلية وعصبية، ولا تمت للـــدين بصــلة، و الواجب على الجميع أن يسعى إلى محاربة مثل هذه الأفكار، بدءا بالبحتمع القبلي؛ لأننا نواجه من المجتمع كثيرا من المشكلات التي تتعلق بين الزوجين، حيث ترتفــع نســـبـ الطلاق". http://www.okaz.com.sa/new/issues/20100205/Con20100205331202.htm (Y) 


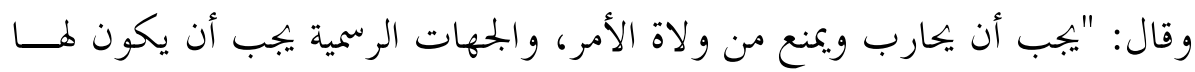

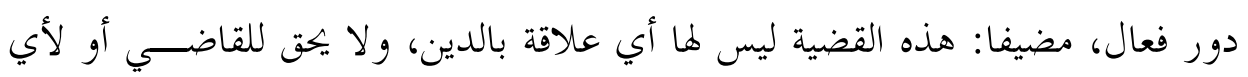

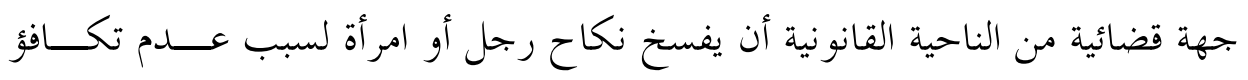
النسب، لعدم وجود نص في القانون ولا في الشرائع ما يسند هذه القضية"(1). ويقول الخضيري قاضي محكمة التمييز : "مسألة كفاءة النسب مختلف فيها شرعا،

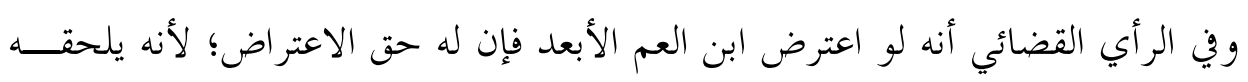

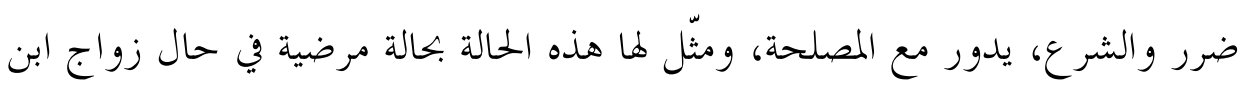

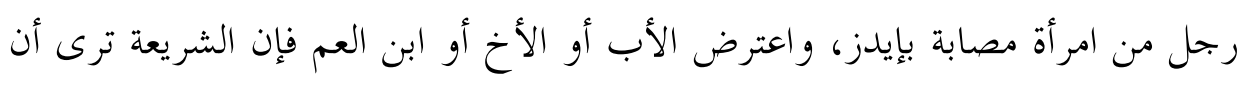

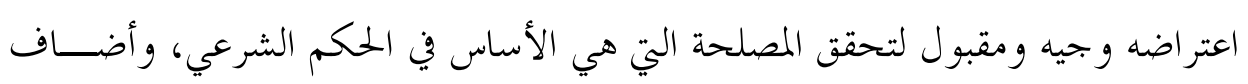

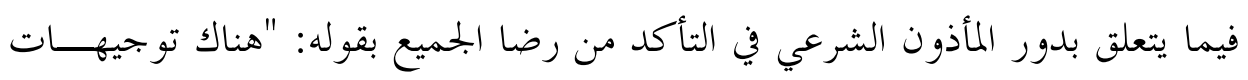

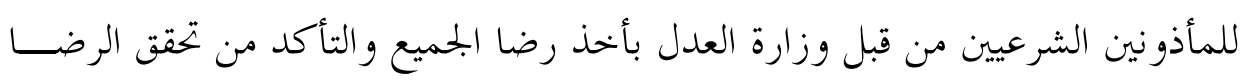

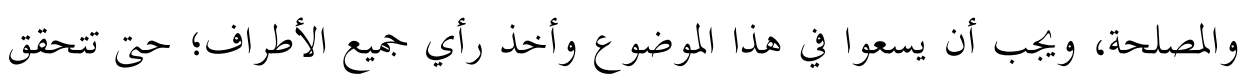

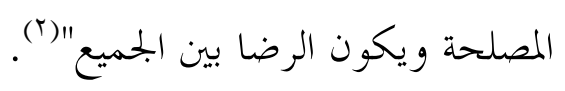

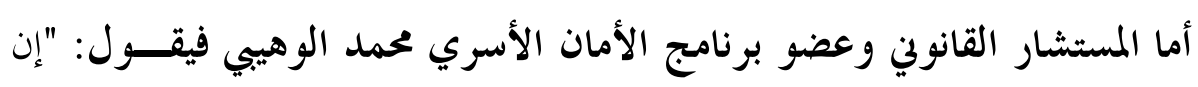

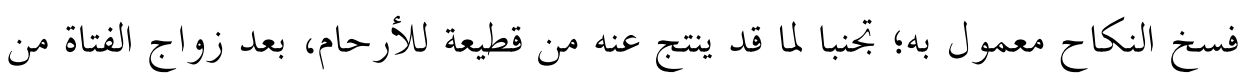

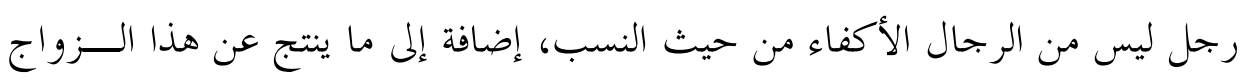
من مضار تمتد لباقي أفراد الأسرة، كعدم زواج باقي أخوات الفتاة وتضررهن بـــزواج

http://www.okaz.com.sa/new/issues/20100205/Con20100205331202.htm ( 1 ) http://www.gulfkids.com/vb/showthread.php?t=421 ( $($ ) 
أختهن، و كذلك الأضرار التي تمتد إلى الزواج ذاته من اضطراب الحياة الزوجية بسبب التفاوت الاجتماعي بين الزوجين، مؤكدا أن فسخ النكاح لعدم تكافؤ النسب يعــود لسلطة القاضي التقديرية في النظر إلى الضرر الذي سيعود على الأسرة والفتاة. إن الزواج غير المتكافئ يتحمل نتيجته ولي أمر الفتاة؛ لعدم سؤاله عن المتقدم لخطبة من تحت ولايته إلا أن المتقدم للخطبة أيضا قد يقوم بالتدليس والخداع وإخفاء حقيقة نسبه عن أهل الفتاة، وللولي هنا طلب إبطال عقد النكاح لوقوعه في التدليس، ولــيس الفسخ، وللقاضي القضاء بعقوبة تعزيرية لزوج الفتاة؛ لقيامه بالتغرير و المخادعة. وقال الوهيي: إن القاعدة في هذا الأمر هي 》الا ضرر ولا ضرارش، فإذا كان زواج الفتاة لا يترتب عليه ضرر يجب عدم فسخ نكاحها، ولكن إذا ترتب على الزواج ضرر كــبير

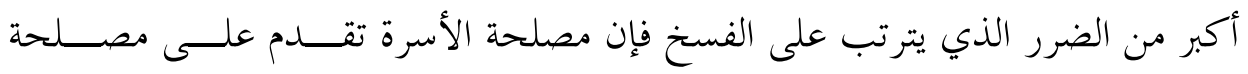
(1)"الفتاة

فيما أوضح المستشار القانولي وعضو جمعية حقوق الإنسان خالد الفاخري: "أنه

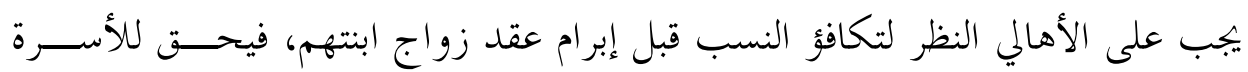

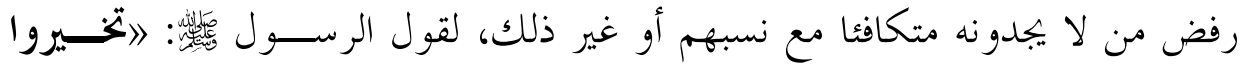

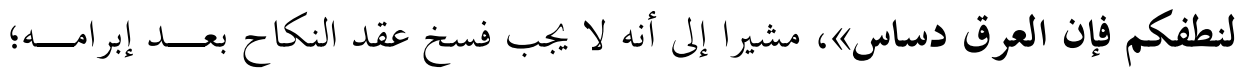
حيث إن الرسول أوصى بالمو افقة على من صلح دينه و خلقه، واستثنى الفاخري مــنـ ذلك من قام بالتغرير و التدليس، عن طريق نسب نفسه إلى غير أصله (r).

http://www.alsharq.net.sa/2013/09/17/945861 (1) http://www.alsharq.net.sa/2013/09/17/945861 ( $(T)$ 
وقد استبعد القاضي السابق في ديوان المظالم الخامي والمستشار القانولي محمد بن

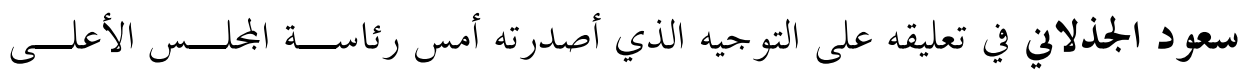

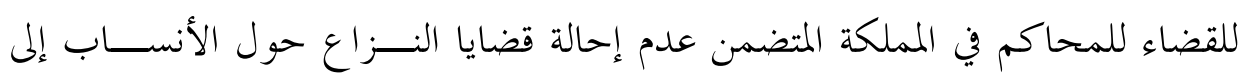
النظر القضائي، بحكم أن الجهة المختصة بالتعديل أو الحذف والإضافة هي وكالة وزارة الداخلية للأحوال المدنية، وقال: توجيه عدم النظر بقضايا الأنساب لا يشمل نــــوعين من الدعاوى: أول الدعاوى هي دعوى المطالبة بفسخ النكاح لعدم تكافؤ النسب؛ لأن دعوى الفسخ لعدم تكافؤ النسب تدور حول طلب فسخ عقد نكاح، وهذا من صميم

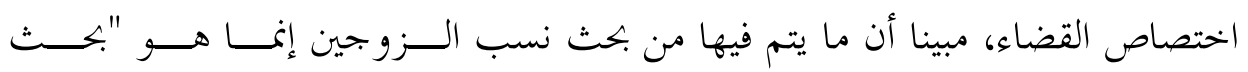
عارض"، وليس هو موضوع الدعوى الأصلي؛ وذلك ليتوصل به إلى الحكم القضــائي

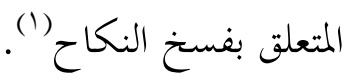




\section{الخاتهت}

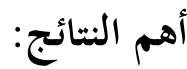

- إن الكفاءة هي مماثلة الزوج زوجته في خصال معتبرة، أو أن يكون أعلى منها،

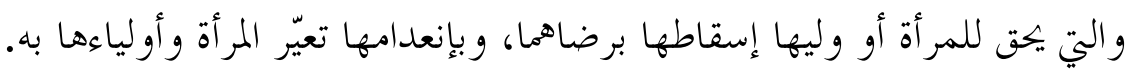
- إن الإحساس بالكفاءة يولد احترام كل طرف للآخر؛ ومن تمح تنظر المرأة إلى زوجها نظرة تقدير واحترام، كما ينظر هو إليها هذه النظرة، وهذا كله يساعد على الألفة ودوام العشرة بينهما، ودوام الحياة الزوجية وتماسك الأسرة، وإيجاد النسل وتربيته التربية الصالحة، وهذا بخلاف ما لو كان الزوج غير كفء لها.

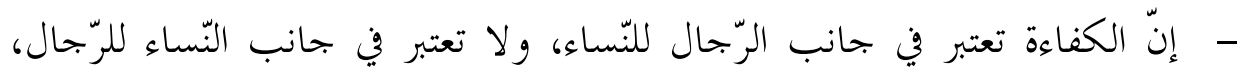
فهو حق في صالح المرأة لا في صالح الرجل، فيشترط أن يكون الرجل مماثلا أو

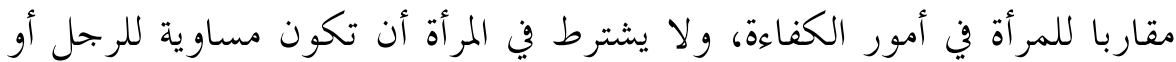

$$
\text { مقاربة له؛ بل يصح أن تكون أقل منه في أمور الكفاءة. }
$$

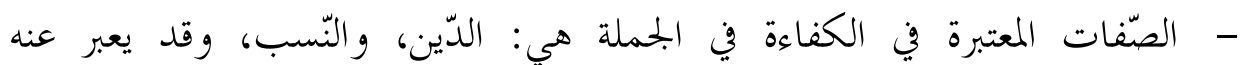

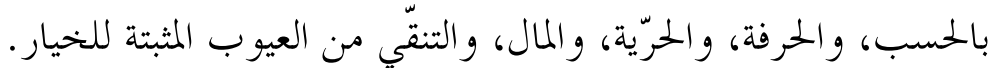
- إن الكفاءة شرط في عقد النكاح، شرط لزوم، ولكن الأولى بالمسلم اختيار من يرضاه ممن لا يلحقه بمناسبته ومصاهرته عيب أو عار، و المتأمل في كام كلام أهل العلم يجد أن المرجع في خصال الكفاءة هو عرف الناس وعادقم، فكل ما عده الناس و اعتبروه من الأنساب والأحساب و الحرف ونحوها فإنه معتبر، ومالا عبرة به فإنه

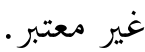


- - إن اشتراط الكفاءة في النسب لصحة النكاح مختلف فيه بين المذاهب، وللحنابلة فيه روايتان، وأكثر أهل العلم على أها ليست شرطا للصحة، و انما شرط لزوم، فلو

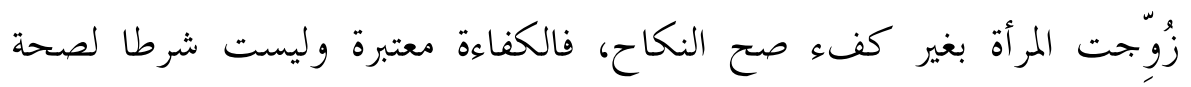
النكاح، وقالوا إن للأولياء أو بعضهم حق المطالبة بفسخ النكاح إذا زوجت المرأة أنساء بغير كفء، لكن أبا حنيفة يقول: إذا رضيت المرأة وبعض الأولياء فليس لباقي الأولياء حق الفسخ. ومالك والشافعي يقولان: إذا زوّج الولي الأقرب فليس

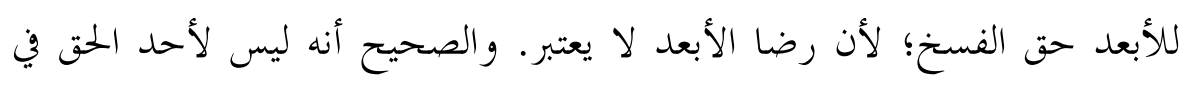
فسخ النكاح مادام النكاح صحيحا. - موضوع التفريق لعدم الكفاءة في عقد النكاح من المو اضيع المندرجة ضمن قضايا محكمة الأحوال الشخصية، إلا أن نظام المرافعات الشرعية لم تتطرق نصوصه إليه،

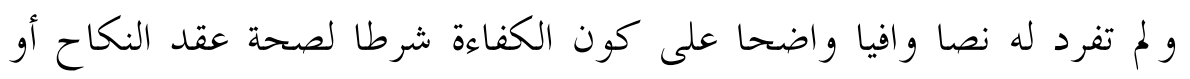
نفاذه أو لزومه، ومن يفسخ العقد، ومتي يمق للأولياء أو المرأة الفسخ وعدمده. - - ولذلك عملت الباحثة على توجيه دعوة للمشرع إلى تنظيم نصوص نظامية

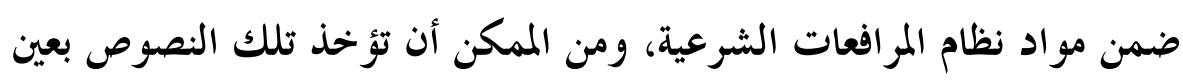
الاعتبار. هذا ونحمد الله الذي يسر كتابة هذا البحث، فهو صاحب الفضل والنعم، فله الحمد كما ينبغي لجلال وجهه و كريم فضله وعظيم إحسانه، و نصلي و نسلم على خاتم رسله وخير خلقه محمد بن عبد الله - صلى الله عليه و آله وصحبه و سلم. *** 


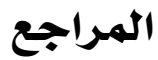

هأحام القر آن للقرطبي، دار احياء التراث العربي، بيروت.

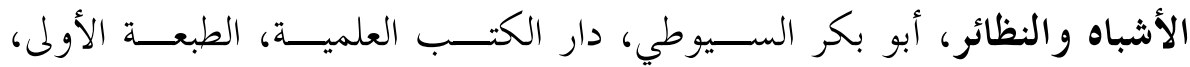
.$\rightarrow \varepsilon \cdot r$

أسنى المطالب في شرح روض الطالب، زكريا الأنصاري، تحقيق: د.محمد تـــامر،

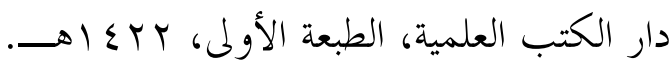

الإنصاف في معرفة الراجح من الحخلاف، علاء الدين المرداوي، دار إحياء التـــراث العربي، الطبعة الثانية. •إعلام الأنام شرح بلوغ المرام، نور الدين عترر، دار الفرفور، دمشق. الاشباه لابن نجيم طبع في دار الفكر بيروت.

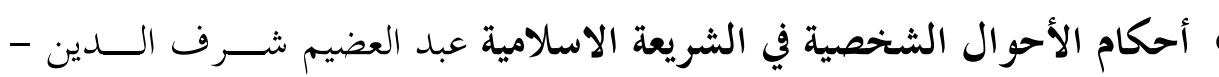

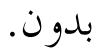
•الأحكام الشرعية للأحوال الشخصية شعبان، زكي الدين - بدون.

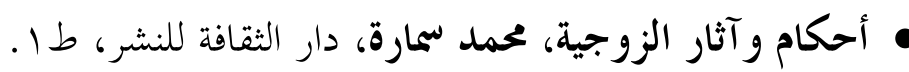
الأحوال الشخصية، محمد أبو زهرة، دار الفكر العربي، القاهرة.

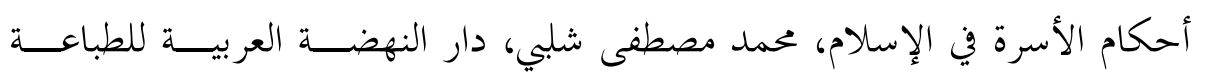
و النشر. أحكام الزواج في ضوء الكتاب والسنة، د. عمر الأشقر، دار النفـــائس، الأردن 
. $199 \vee-\longrightarrow 1 \leqslant r \wedge 61 b$

الأحكام الشرعية في الأحوال الشخصية، محمد قدري باشا، دار ابن حزم.

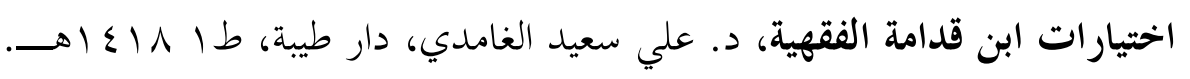
البحر الرائق شرح كنــز الدقائق، ابن بنهم الحنفي، دار المعرفة، الطبعة الثانية.

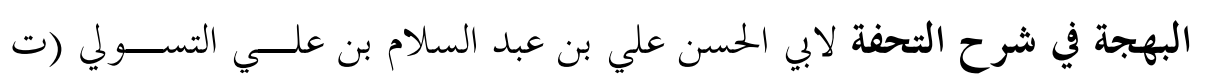

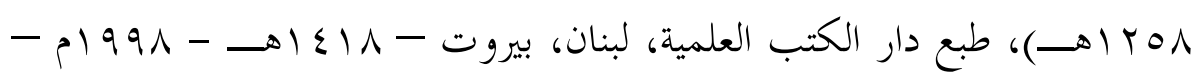
$.1 b$ بدائع الصنائع في ترتيب الشرائع، لإمام الكاساني، دار الكتب العلمية، بيروت،

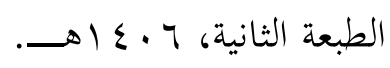

البناية في شرح الهداية، أبو محمد محمود بن أحمد العيني، دار الفكر، ـ 19 ام.

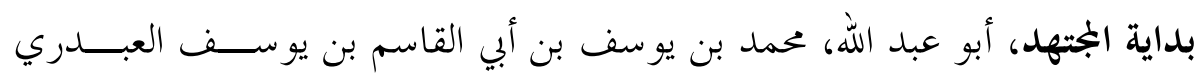

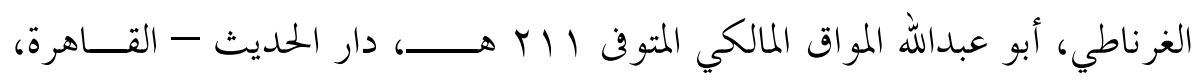

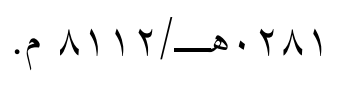

بداية الجنتهد، لابن رشد - تحقيق: عبد الحليم محمد عبد الحليم.

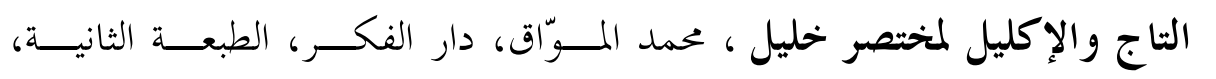

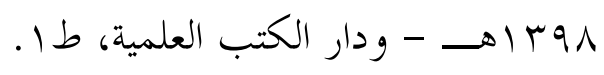
تاج العروس من جواهر القاموس، دار الهداية. تحفة الحبيب على شرح الخطيب، سليمان بن محمد بن عمر البجيرمــي المتــوفى ا ا T Mــ، دار الكتب العلمية، لبنان. 
تحفة الفقهاء، محمد بن أحمد بن أبي أحمد، أبو بكر علاء الدين السمرقندي المتوفى: نهو ·ـ ـهــ، دار الكتب العلمية، بيروت - لبنان. التعريفات للجرجاتي، علي بن محمد بن علي الزين الشريف الجرجــــاني المتــــفئ: 1 11 1هــ، دار الكتب العلمية، بيروت - لبنان.

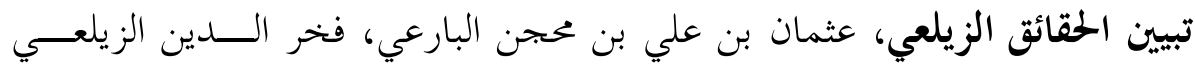

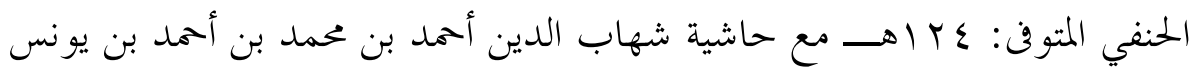
ابن إسماعيل بن يونس، المطبعة الكبرى الأميرية بولاق، القاهرة، الطبعة الأولى.

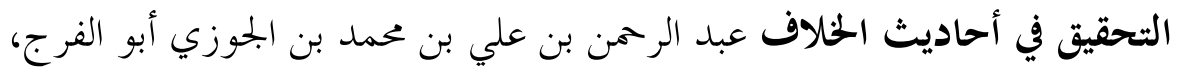

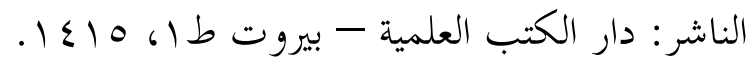
تفسير ابن كثير، أبو الفداء إسماعيل بن عمر بن كثير القرشي البصري ثم الدمشقي

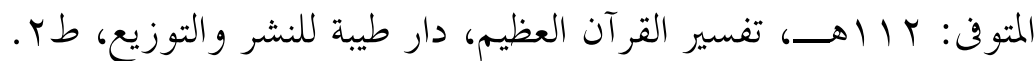
بلغة السالك لأقرب المسالك المعروف بحاشية الصاوي على الشرح الصغير، أبو

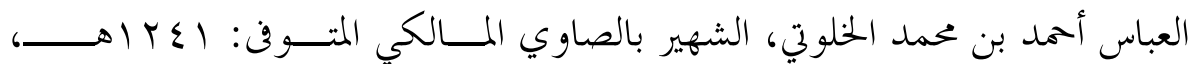
الناشر: دار المعارف، بدون طبعة وبدون تاريخ. همرة النسب لابن الكلبي، دار النهظة العربية.

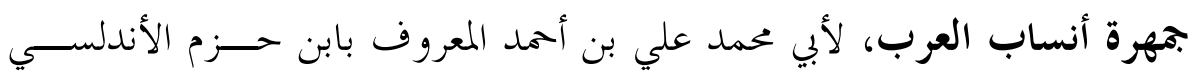

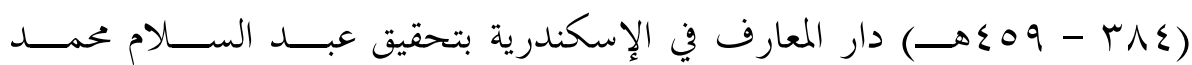
هارون. حاشية حاشية الدسوقي على الشرح الكبير، محمد عرفه الدسوقي، دار الفكر - 
حاشية العدوي على شرح كفاية الطالب الرباني، علي الصعيدي العدوي المالكي، دار الفكر، بيروت. • حاشية البجيرمي البيجرمي على شرح المنهج، سليمان بن محمد بن عمر البجنيرمي المصري الشافعي، مطبعة الحلبي.

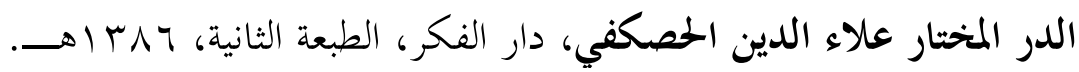
درر الحكام شرح غرر الأحكام، منلا خسرو، بدون معلومات نشر.

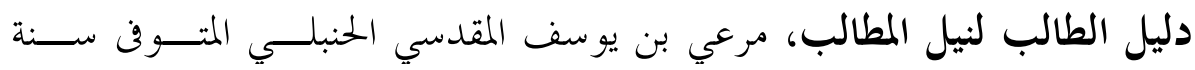
بr • اهــ، مؤسسة الرسالة.

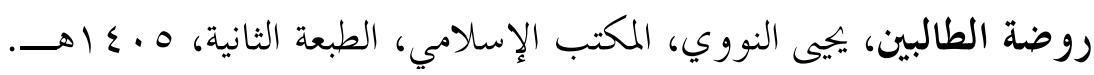
زاد المستقنع في اختصار المقنع، موسى الحجاوي، دار القلم، الطبعة الثامنة.

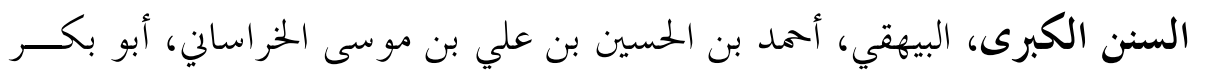

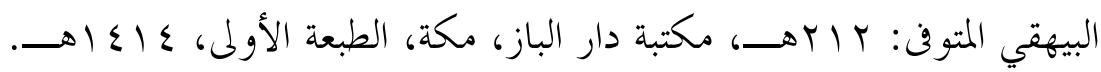
سنن النسائي، أبو عبد الرحمن أحمد بن شعيب بن علي الخراساني، النسائي المتوفن:

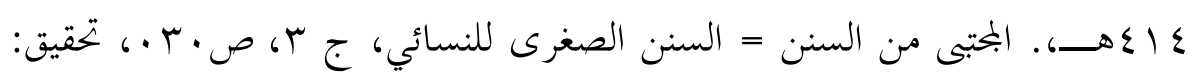

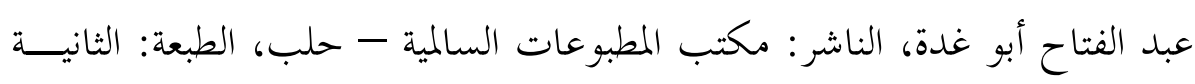
تحقيق: د.عبد الغفار سليمان، دار الكتب العلمية، الطبعة الأولى.

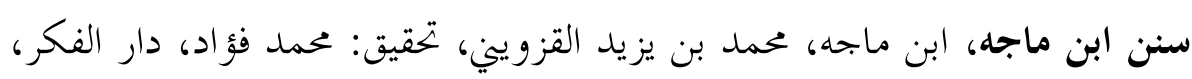
بيروت. سنن الدار قطني، أبو الحسن الدار قطني، تحقيق: السيد عبد الله هاشم يمــاني، دار

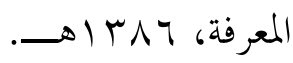


شرح مختصر خليل للخرشي، أبي عبد الله محمد بن عبد الله بن علــي الخرشـي

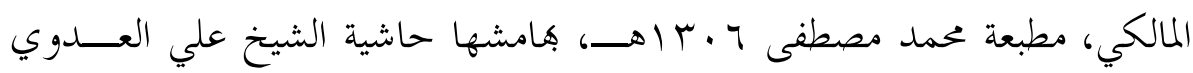
على الشرح، ونسخة مطبعة الاميرية بولاق مصر سنة 9 اب اهـــ. شرح قانون الأحوال الثخصيه العراقي وزارة التعليم العالي والبحـــث العلمــي . $\rightarrow \leqslant \ldots$

شرح منتهى الإرادات، منصور بن يونس بن إدريس البهوتي الحنبلــي . . 1 -

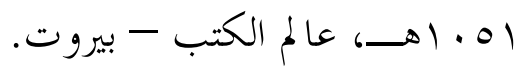

• شرح مخنصر الروضة، سليمان بن عبد القوي الصرصري الحنبلي، دار التدمرية.

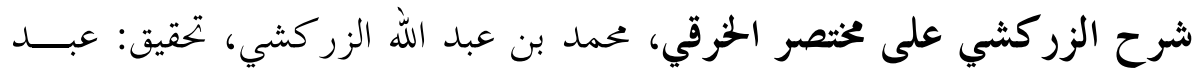

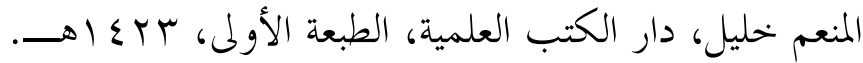
شرح الزركشي تحقيق: عبد الله الجبرين.

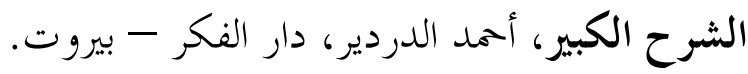

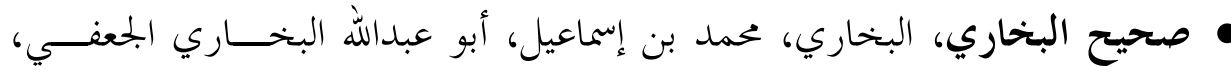

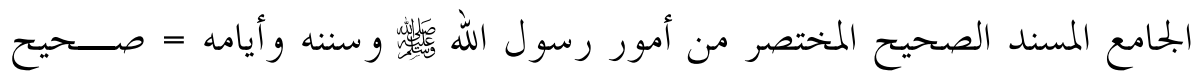
البخحاري، تحقيق: محمد زهير بن ناصر الناصر، دار طوق النجـــاة، مصــورة عــنـ السلطانية بإضافة ترقيم محمد فؤ اد عبد الباقي ط لـ

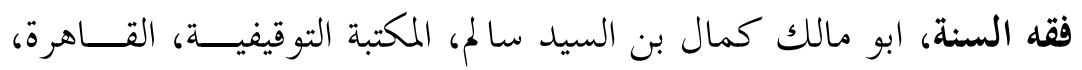

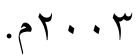
هالطبقات الكبرى، لابن سعد ، أبو عبد الله محمد بن سعد بن منيع الهاشمي بالولاء، 
البصري، البغدادي المعروف بابن سعد (المتوفى: اعـهـــ)، الطبقــات الكـــبرى،

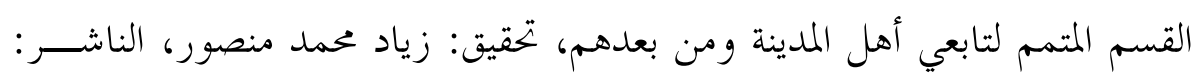

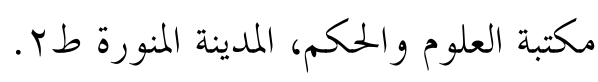

• العلم الظاهر في نفع النسب الطاهر لابن عابدين لحنفي، ضمن بحموع رسائله.

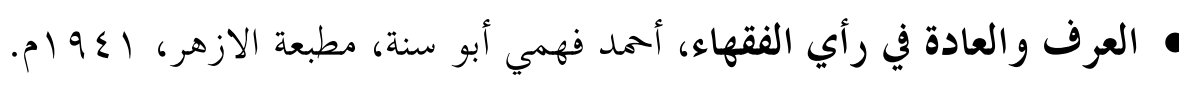
• الفواكه الدواني على رسالة ابن أبي زيد القيروالي، أحمد بن غنيم بن سالم بن مهنا النفراوي الأزهري المالكي، دار الكتب العلمية، بيروت.

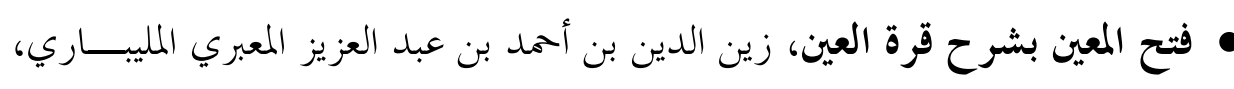

$$
\text { دار بن حزم، ط الم المعاح }
$$

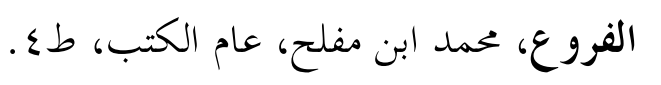
• فتح القدير الكمال بن الهمام، دار الفكر، الطبعة الثانية. الفقه الإسلامي وأدلثه للزحيلي، دار الفكر، دمشق. الفتاوى الهندية .

فنح الوهاب شرح منهج الطلاب زكريا الأنصاري، دار الكتب العلمية، الطبعــة

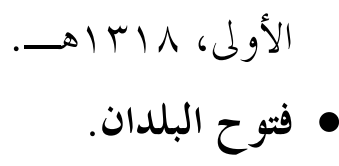
الفهرست لابن النديم، مكتبة الخابجي، القاهرة.

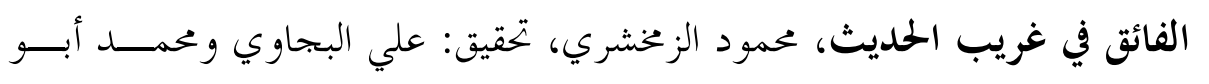
الفضل، دار المعرفة، الطبعة الثانية. 
القوانين الفقهية لابن جزى، دار عباس الباز، مكة المكرمة.

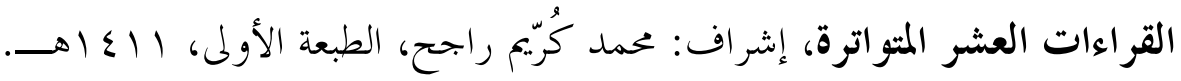
القاموس الفقهي لغة واصطلاحاً، سعدي أبو جيب. الكافي في فقه ابن حنبل، عبد الله بن قدامة، دار الكتب العلمية، الطبعــة: الأولى،

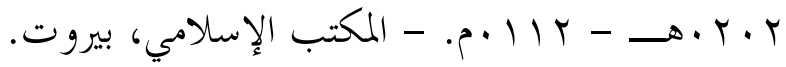
كثاف القناع عن متن الاقناع البهوتي، منصور بن يونس بن إدريـسـ البــــوتي،

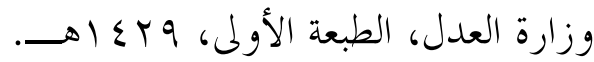

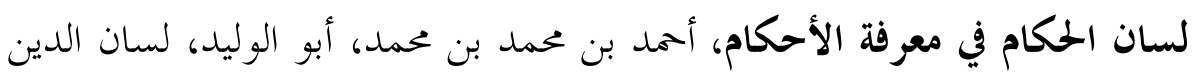

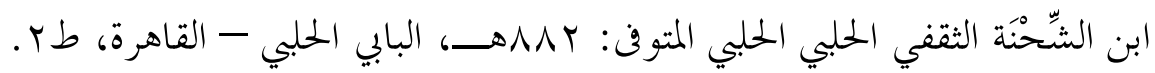

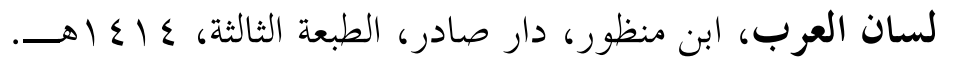
اللباب في شرح الكتاب، عبد الغني الغيي الميداني، دار المعرفة. معجم مقاييس اللغة، أحمد بن فارس بن زكريا، دار الفكر.

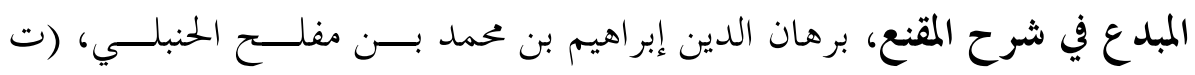

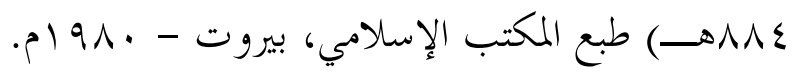
ه المصباح المنير، تأليف العلامة أحمد بن محمد بن علي الفيومي المقري، طبع مكتبــة

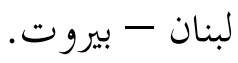
معجم المصطلحات والألفاظ الفقهية، د. محمد عبد المنعم. المفصل في تاريخ العرب، جواد علي، دار الساقي، طـ . مسند مسند الامام أحمد بن حنبل، جrع، ص جا T، تحقيق: شعيب الأرنــؤوط 
عادل مرشد، وآخرون، إشر اف: د عبد الله بن عبد المحســن التركــي، مؤسســة

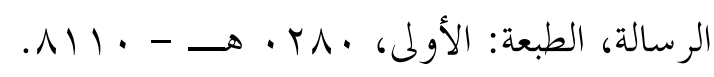

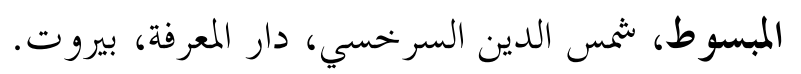

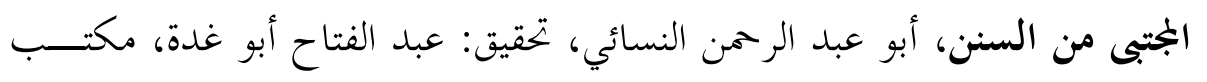

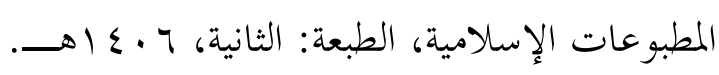

مسند الإمام أحم، للأمام أحمد بن حنبل، مؤسسة قرطبة، بدون تاريخ.

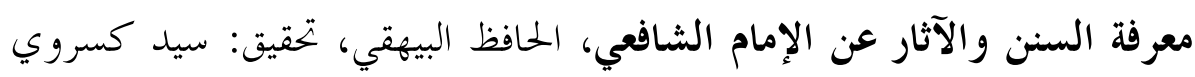
حسن، دار الكتب العلمية. منار السبيل شرح الدليل للشيخ إبراهيم بن محمد بن سالم بن ضويان - الطبعــة الأولى سنة 99 ب اهــ، الناشر المكتب الإسلامي.

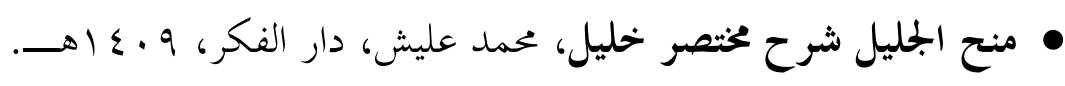

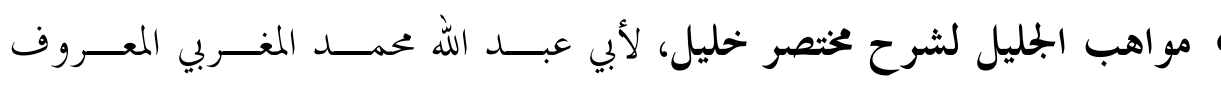

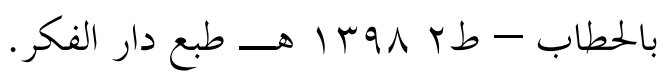
معجم مقاييس اللغة. مجمع الأفر في شرح ملتقى الأبحر لشيخي زاده، تحقيق: عمـــــان المنصـــور، دار

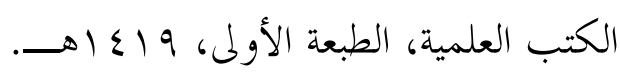

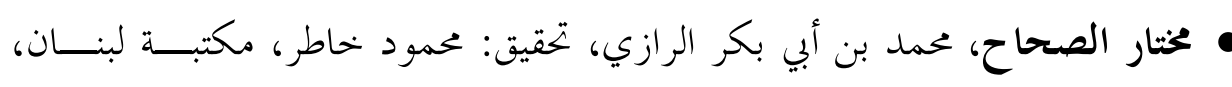
. $1 \leqslant 10$ مغني الختاج المى معرفة ألفاظ المنهاج للشيخ محمد الشربيني الخطيب. الناشــــــار إحياء التراث العربي. 
المفصل في أحكام المر أقة عبد الكريم زيدان، مؤسسة الرسالة.

ه الموسوعة الفقهيّة الكويتية، وزارة الأوقاف و الشئون الإسلامية، الطبعة الثانية.

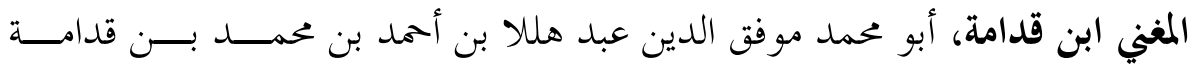
الجماعيلي المقدسي ثم الدمشقي الحنبلي، الشهير بابن قدامة المقدســي (المتـــوفن:

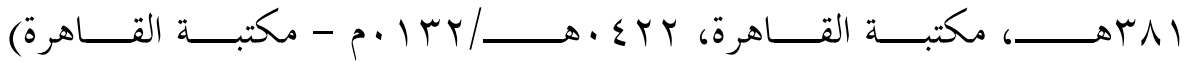

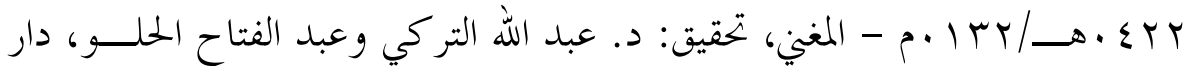

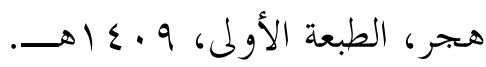
• مختصر القدوري على مذهب الإمام أبي حنيفة، مطبعة مصطفى البــابي الحلــبي

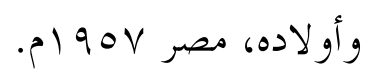
• بجمع الأفر في شرح ملتقى الأبحر داماد أفندي، عبد الرحمن بن محمد بن سليمان

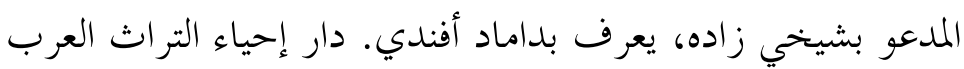

منح الجليل شرح مختصر خليل محمد بن أحمد بن محمد عليش، أبو عبد الله المالكي

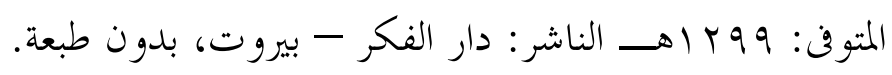
الخيط البرهاني في الفقه النعمالي، محمود بن أحمد بن عبد العزيز مازه البخهــاري،

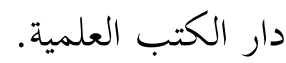

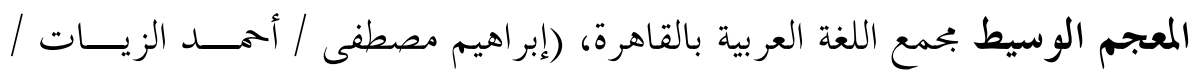

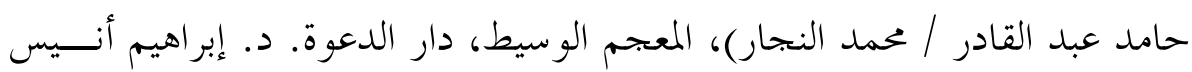
وآخرون، دار المعارف، الطبعة الثانية. المقتضب من كتاب جمهرة النسب، لياقوت الحموي (OV0 - ب rا7هـ)، وهـــ 
خلاصةٌ لكتاب جمهرة النسب للكبي، قام بطباعته وتحقيقه و نشره الأستاذ نــاجي حسن. المقنع في فقه إمام السنة أحمد بن حنبل - لموفق الدين ابن قدامة المقدسـي مــع حاشية بخط الشيخ سليمان بن الشيخ عبد الله بن الشيخ محمد بن عبد الوهاب ل الطبعة الثانية. نيل المآرب بشرح دليل الطالب، مرعي بن يوسف الكرمي، دار الكتب العلمية،

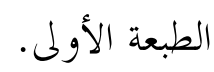

النسب ومدى تأثير المستجدات العلمية في إثباته. هاية الارب في معرفة انساب العرب لأبي العباس أحمد المعــروف بالقلقشـــدي $(-\Delta Y 1)$ • نيل الأوطار، الشوكاني، محمد علي محمد، الشوكاني اليمني المتوفى: (11 (1)هـ) تحقيق: عصام الدين الصبابطي، دار الحديث، مصر، طا - دار الجيل، بيروت.

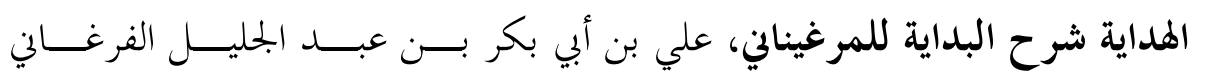

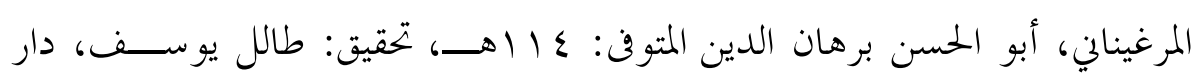
إحياء التراث العربي، بيروت - لبنان. 
